\title{
ARTICLE
}

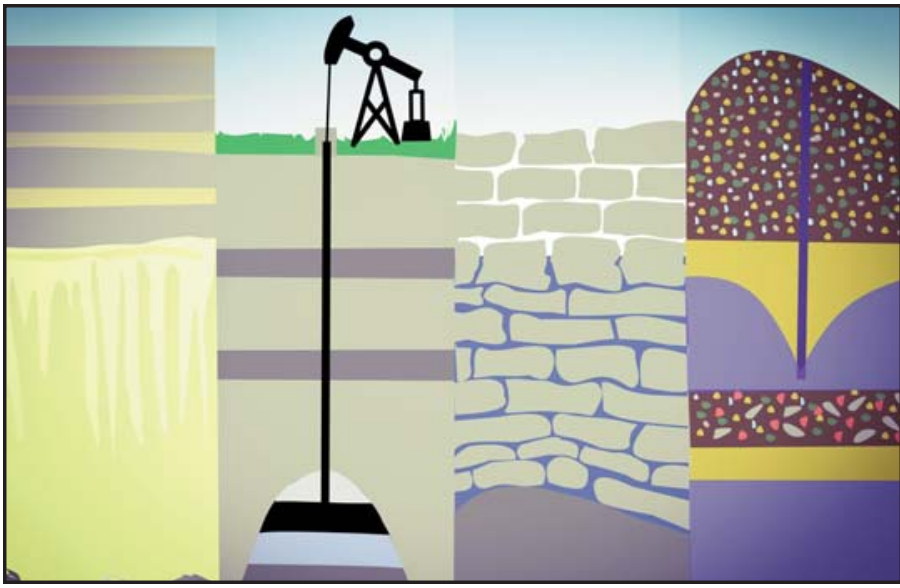

\section{A Hydrostratigraphic Framework for the Paleozoic Bedrock of Southern Ontario}

\author{
Terry R. Carter ${ }^{1}$, L.D. Fortner ${ }^{2}$, H.A.J. Russell ${ }^{3}$, \\ M.E. Skuce ${ }^{4}$, F.J. Longstaffe ${ }^{5}$ and S. Sun ${ }^{5}$ \\ ${ }^{1}$ Carter Geologic \\ 35 Parks Edge Crescent, London, Ontario, N6K 3P4, Canada \\ E-mail:terry.carter@cartergeologic.com
}

${ }^{2}$ Ministry of Natural Resources and Forestry, Government of Ontario 659 Exeter Road, London, Ontario, N6E 1L3, Canada

${ }^{3}$ Geological Survey of Canada

601 Booth Street, Ottawa, Ontario, K1 A OE8, Canada

${ }^{4}$ Isobrine Solutions Inc.

933060 Avenue NW, Edmonton, Alberta, T6E 0C1, Canada

${ }^{5}$ Department of Earth Sciences, The University of Western Ontario 1151 Richmond Street N., London, Ontario, N6A 5B7, Canada

\section{SUMMARY}

Groundwater systems in the intermediate to deep subsurface of southern Ontario are poorly understood, despite their value for a number of societal uses. A regional hydrostratigraphic framework is a necessary precursor for improving our understanding of groundwater systems and enabling development of a 3-D hydrostratigraphic model to visualize these ground- water systems. This study is a compilation and integration of published and unpublished geological, hydrogeological, hydrochemical and isotopic data collected over the past 10 years to develop that framework.

Bedrock is covered by a thin veneer of surficial sediments that comprise an aquifer/aquitard system of considerable local variability and complexity. Aquifers in the bedrock are thin and regionally extensive, separated by thick aquitards, within a welldefined lithostratigraphic framework and a well-developed hydrochemical depth zonation comprising a shallow fresh water regime, an intermediate brackish to saline sulphur water regime, and a deep brine regime of ancient, evaporated seawater. Occurrence and movement of groundwater in shallow bedrock is principally controlled by modern (Quaternary) karstic dissolution of subcropping carbonate and evaporite rocks, and in the intermediate to deep subsurface by paleokarst horizons developed during the Paleozoic. Flow directions in the surficial sediments of the shallow groundwater regime are down-gradient from topographic highs and down the regional dip of bedrock formations in the intermediate regime. Shallow karst is the entry point for groundwater penetration into the intermediate regime, with paleo-recharge by glacial meltwater and limited recent recharge by meteoric water at subcrop edges, and down-dip hydraulic gradients in confined aquifers. Hydraulic gradient is up-dip in the deep brine regime, at least for the Guelph Aquifer and the Cambrian Aquifer, with no isotopic or hydrochemical evidence of infiltration of meteoric water and no discharge to the surface.

Fourteen bedrock hydrostratigraphic units are proposed, and one unit comprising all the surficial sediments. Assignment of lithostratigraphic units as hydrostratigraphic units is based principally on hydrogeological characteristics of Paleozoic bedrock formations in the intermediate to deep groundwater regimes, below the influence of modern meteoric water. Carbonate and evaporite rocks which form aquitards in the subsurface may form aquifers at or near the surface, due to karstic dissolution by acidic meteoric water, necessitating compromises in assignment of hydrostratigraphic units.

\section{RÉSUMÉ}

Les systèmes d'eaux souterraines du sous-sol intermédiaire à profond du sud de l'Ontario sont mal compris, malgré leur valeur pour de nombreux usages par la société. Un cadre hydrostratigraphique régional est un préalable nécessaire à l'amélioration de notre compréhension des systèmes d'eaux souterraines et au développement d'un modèle hydrostratigra- 
phique 3D pour visualiser ces systèmes d'eaux souterraines. Cette étude est une compilation et une intégration de données géologiques, hydrogéologiques, hydrochimiques et isotopiques publiées et non publiées recueillies au cours des 10 dernières années afin de développer ce cadre.

Le substrat rocheux est recouvert d'un mince placage de sédiments de surface qui comprend un système d'aquifères et d'aquitards d'une variabilité et d'une complexité locales considérables. Les aquifères du substrat rocheux sont minces et étendus au niveau régional, séparés par des aquitards épais, dans un cadre lithostratigraphique bien défini et une zonation hydrochimique verticale bien développée comprenant un régime peu profond d'eau douce, un régime intermédiaire d'eau sulfureuse saumâtre à saline et un régime profond de saumure résultant de l'évaporation d'eau de mer ancienne. La présence et le mouvement des eaux souterraines dans le substrat rocheux peu profond sont principalement contrôlés par la dissolution karstique moderne (quaternaire) des roches carbonatées et évaporitiques sub-affleurantes, et dans le sous-sol intermédiaire à profond par les horizons paléokarstiques développés au Paléozoïque. Les directions d'écoulement des eaux dans les sédiments de surface du régime peu profond sont en aval des sommets topographiques et en aval du pendage régional des formations de substrat rocheux dans le régime intermédiaire. Le karst peu profond est le point d'entrée pour l'infiltration des eaux souterraines dans le régime intermédiaire, avec une paléo-recharge d'eau de fonte glaciaire et une recharge récente limitée d'eau météorique aux bords de sous-affleurement, et un gradient hydraulique en aval-pendage dans les aquifères confinés. Le gradient hydraulique est en amont-pendage dans le régime profond de saumure, au moins pour l'aquifère de Guelph et l'aquifère du Cambrien, sans indication isotopique ou hydrochimique d'infiltration d'eau météorique et sans déversement à la surface.

Quatorze unités hydrostratigraphiques du substrat rocheux sont proposées, et une unité comprenant tous les sédiments de surface. L'attribution des unités lithostratigraphiques en tant qu'unités hydrostratigraphiques repose principalement sur les caractéristiques hydrogéologiques des formations du substrat rocheux du Paléozoïque dans les régimes intermédiaires à profonds des eaux souterraines, sous l'influence des eaux météoriques modernes. Les roches carbonatées et évaporitiques qui forment les aquitards dans le sous-sol peuvent former des aquifères à la surface ou près de la surface, en raison de la dissolution karstique par l'eau météorique acide, ce qui nécessite des compromis dans l'attribution des unités hydrostratigraphiques.

Traduit par la Traductrice

\section{INTRODUCTION}

An understanding of geological controls on groundwater occurrence and quality is important as population growth elevates demands for a sustainable supply of water for residential and industrial use, both in Ontario and worldwide. Groundwater studies to date in southern Ontario have focussed on aquifers in the shallow subsurface that are able to meet quality standards for potability (e.g. Sharpe et al. 2014). Groundwater in the intermediate to deep subsurface has quality constraints that has discouraged its investigation. In some parts of North America these deeper waters are increasingly being considered as potential resources, necessitating a better understanding of their hydrogeological and hydrostratigraphic relationships. For example, the states of California, Florida, Texas, Kansas, Virginia and Utah currently treat brackish to saline groundwater to remove dissolved solids to provide public water supply for human consumption (Dieter et al. 2018). In the United States the potential volume of brackish groundwater is conservatively estimated at $35 \times$ the total annual volume of fresh groundwater utilized for all uses (Stanton et al. 2017). Comparable data are not available for Canada.

The feasibility of utilizing brackish and saline groundwater is limited by legal and environmental considerations, hydrochemical composition and lack of data on recharge mechanisms and sustainability. Without efficient recharge pathways, large-scale development of these groundwater resources will result in groundwater depletion. In Canada, groundwater sustainability has been identified as a significant knowledge gap (Canadian Council of Ministers of the Environment 2010).

Deep brine aquifers in the northeastern United States and Ontario have been proposed for sequestration of carbon dioxide emissions from fossil fuel power plants and cement plants (e.g. Shafeen et al. 2004; Shafeen and Carter 2009). High-calcium brine from select deep aquifers in southern Ontario is utilized for ice control on Ontario's 400 series expressways. Intermediate to deep aquifers in southern Ontario are presently utilized for disposal of saline oil-field fluids, which are a by-product of oil and natural gas production. In the past, some of these aquifers were also utilized for disposal of industrial wastes (Raven et al. 1990). Deep aquifers and aquitards are also important hydrochemical indicators of the long residence time of deep subsurface groundwaters, thus helping establish a safety case for deep disposal and long-term isolation of nuclear wastes (e.g. Hobbs et al. 2011; Intera Engineering Ltd. 2011; Clark et al. 2013). Brackish and saline groundwater may be utilized for underground injection to support enhanced oil production (e.g. Craig 1993).

To provide a framework for supporting these various subsurface management strategies a 3-D geological model has been constructed of the Paleozoic sedimentary sequence (Carter et al. 2019) and the overlying sediments (Logan et al. 2020). This lithostratigraphic framework requires reclassification and rationalization to support development of a 3-D hydrostratigraphic model which is in progress. Frey et al. (2020) recently developed a proof-of-concept fully integrated groundwater-surface water model for southern Ontario.

The objective of this study is to establish a high-level hydrostratigraphic classification of the aquifer and aquitard systems of southern Ontario within the shallow, intermediate, and deep hydrochemical groundwater regimes identified by Carter and Fortner (2012) and Sharpe et al. (2014). The focus is on groundwater systems in the intermediate to deep bedrock, which are largely non-potable, and evidence for interaction with shallow groundwater systems. Understanding the geological context and the geological processes that created 
pathways for groundwater movement guides and informs development of conceptual models of groundwater flow.

The classification is based on a wealth of data compiled from both published and unpublished sources, including water intervals records from petroleum wells, stable isotope and hydrochemical analyses, interpreted flow directions, stratigraphic relationships, geological controls on groundwater occurrence and movement, field observations, hydraulic conductivity measurements, DNA microbial profiling, faults and fractures, and karst studies.

\section{Previous Hydrostratigraphic Classifications}

Singer et al. (2003) were the first to attempt a regional classification of aquifers for southern Ontario. Their focus was exclusively on shallow potable water aquifers in the unconsolidated sediments and the shallow bedrock relying on water well records of the Water Well Information System (WWIS) of the Ontario Ministry of Environment, Conservation and Parks. The classification preceded recognition of the occurrence of a regionally extensive and laterally connected fresh water aquifer at the contact (contact aquifer) between the Paleozoic bedrock of southern Ontario and the overlying unconsolidated sediments (e.g. Dillon Consulting Ltd. and Golder Associates Ltd. 2004; Husain et al. 2004; Strynatka et al. 2007; Carter and Fortner 2012).

For the northwestern part of the study area, including Bruce and Huron counties, Intera Engineering Ltd. (2011) proposed an assignment that resolved the lithostratigraphy into nine hydrostratigraphic units within three hydrogeological systems. The classification was based largely on very detailed geological, hydrochemical, hydrogeological and isotopic data acquired from 6 deep $(450-905 \mathrm{~m})$ and 3 shallow $(<200 \mathrm{~m})$ boreholes drilled at the Bruce Power nuclear generating station (Bruce site) on Lake Huron, in Bruce County. The three hydrogeological systems are analogous to the three hydrochemical regimes identified by Sharpe et al. (2014) and used in the present study: shallow, intermediate, and deep. The 15 hydrostratigraphic units of the present study are similar, with differences due largely to representation of younger stratigraphic units and regional facies variations not present at the Bruce site.

A proof-of-concept 3-D integrated groundwater-surface water numerical model of southern Ontario developed by Aquanty Inc. uses 5 sediment layers and 12 bedrock layers (Frey et al. 2020). Bedrock hydrostratigraphic layers are similar to those considered in the present study.

\section{GEOLOGICAL SETTING}

The study area includes all southern Ontario west of the Frontenac Arch, with the exception of Manitoulin Island, and extends to the international boundary with the United States beneath lakes Huron, St. Clair, Erie, and Ontario, for a total area of approximately $110000 \mathrm{~km}^{2}$ (Fig. 1).

Southern Ontario is underlain by marine sedimentary rocks deposited in a shallow epeiric sea that periodically covered this part of eastern North America during the Paleozoic Era from approximately 501 to $250 \mathrm{Ma}$. The Paleozoic strata uncon- formably overlie Precambrian crystalline metamorphic rocks of the Canadian Shield, over $1 \mathrm{Ga}$, which are exposed at the surface in northern Ontario and large parts of eastern Ontario. Southern Ontario straddles a broad ridge in these Precambrian rocks known as the Algonquin Arch, and its southwestern extension, the Findlay Arch. A fault-bounded structural depression known as the Chatham Sag separates the two arches (Fig. 1). The Precambrian rocks were eroded to a low relief peneplain during an extended period of subaerial exposure lasting perhaps 450 million years (R.M. Easton personal communication 2021). Paleozoic strata are deposited unconformably on this eroded surface.

The Paleozoic strata dip shallowly at 3 to $6 \mathrm{~m} / \mathrm{km}$ along the crests of the arches into the Chatham Sag, and at 3.5 to 12 $\mathrm{m} / \mathrm{km}$ down the flanks of the arches westwards into the Michigan Basin and southwards into the Appalachian Basin (Armstrong and Carter 2010). Regional dip generally increases with depth and with distance away from the crest of the arch. The eroded edges of the shallowly dipping formations form northwest- to southeast-trending subcrop belts and carbonatecapped cuestas with progressively older units exposed at surface or subcropping beneath surficial sediments towards the east and north (Fig. 1) and create opportunities for infiltration of meteoric water into the subsurface along porous and permeable horizons in the bedrock formations.

The Paleozoic strata are formally subdivided into $\sim 70$ formations (Fig. 2). Rock types include limestone, dolostone, sandstone, shale, siltstone, anhydrite, and beds of halite (Armstrong and Carter 2010). In general, strata in the Appalachian Basin are dominated by clastic sedimentary rocks (shale, siltstone, sandstone), while those in the Michigan Basin are predominantly carbonate rocks (limestone, dolostone) with some thick beds of halite and anhydrite/gypsum. Maximum preserved thicknesses are $4800 \mathrm{~m}$ in the Michigan Basin to the west and $7000 \mathrm{~m}$ in the Appalachian Basin to the southeast (Armstrong and Carter 2010), with thickness in southwestern Ontario limited to $\sim 1500 \mathrm{~m}$ within the Chatham Sag beneath Lambton County and west-central Lake Erie.

Subsidence in the Michigan Basin had begun by the Late Cambrian with subsequent intermittent periods of subsidence and uplift, continuing into the Late Jurassic (Sloss 1988; Howell and van der Pluijm 1990; Brunton and Brintnell 2020). The cause of subsidence is not well established and has been variously ascribed to a mantle plume or to a far-field response to compressional effects of Appalachian tectonics (see discussion by Brunton and Brintnell 2020). The Appalachian Basin formed in response to major continental collision events that resulted in four major orogenies: the Taconic (mid Ordovician to early Silurian), Salinic (Silurian), Acadian (Devonian), and Alleghanian (Pennsylvanian to Permian) orogenies (Johnson et al. 1992; Ettensohn 2008).

Depositional pattern, thickness, and structure of Paleozoic strata were controlled by episodic basinal subsidence and archcentred uplift in response to both orogenic and epeirogenic forces generated during the Appalachian orogenies (Johnson et al. 1992). Episodes of regional crustal uplift periodically exposed the strata to erosion, creating regional disconformities 


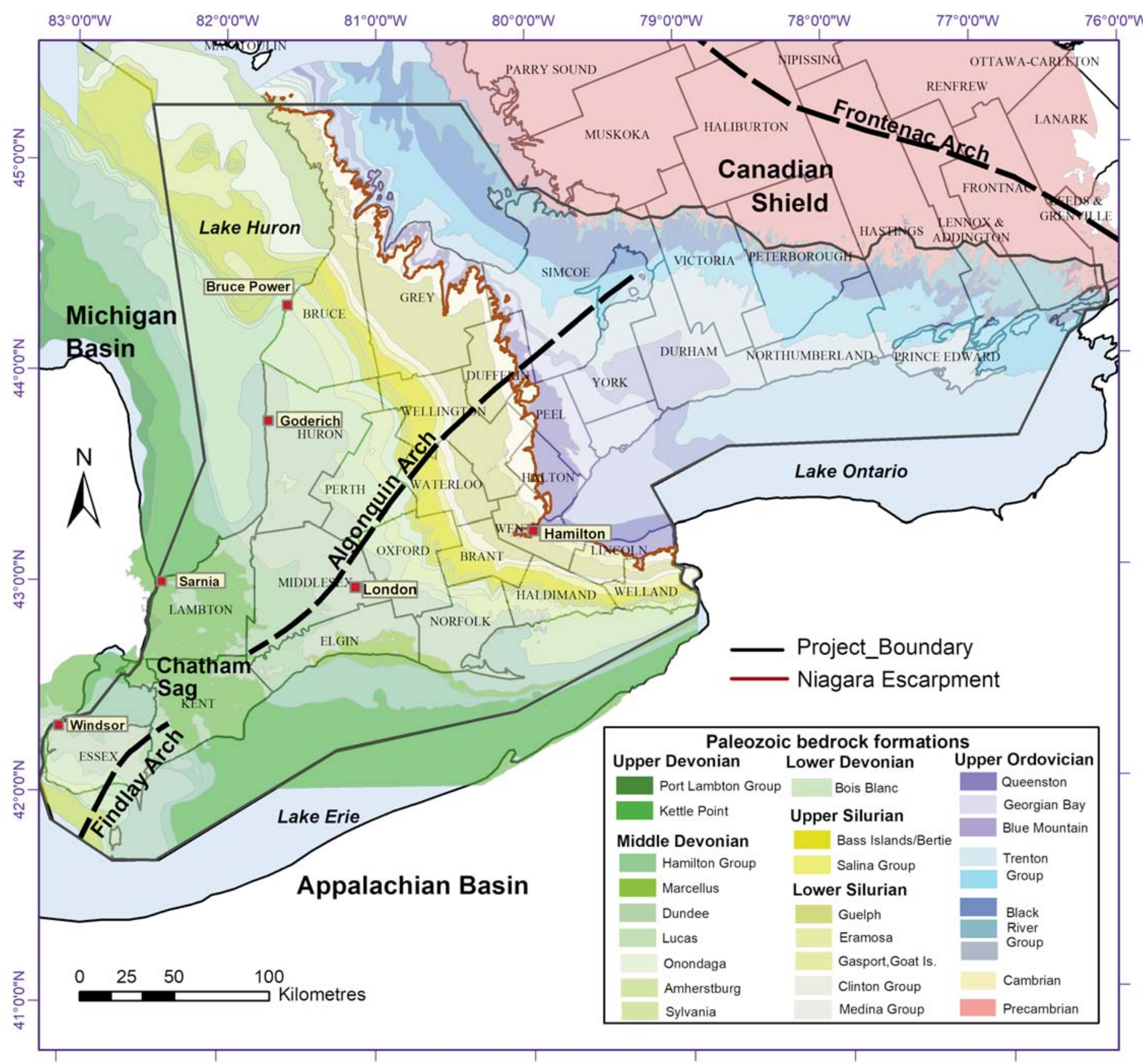

Figure 1. Bedrock geology of southern Ontario showing bedrock formations and groups of formations, structural arches, and basins, adapted from Carter et al. (2019). County boundaries are shown for geographic reference.

(Fig. 2). Near-surface carbonate and evaporite rocks experienced karstic dissolution by acidic surface waters during these exposure episodes. Burial by younger strata during subsequent periods of sea-level rise preserved these paleokarst horizons in the subsurface.

Approximately 250 million years ago tectonic uplift elevated southern Ontario above sea level, beginning an extended period of post-Paleozoic weathering and erosion, forming an angular unconformity between the bedrock and surficial sediments (Johnson et al. 1992).

\section{Physiography, Bedrock Topography and Quaternary Geology}

Several episodes of continental glaciation affected southern Ontario from 1.8 million to 10000 years ago. Twenty thousand years ago all of Ontario was covered by the most recent of these glaciation events, the Laurentide Ice Sheet (LIS) (Barnett 1992). On its retreat, the glaciers left behind a complex terrain of glacial landforms and a wide variety of clastic sediments that range in thickness from a few metres to a maximum of $250 \mathrm{~m}$, averaging tens of metres in thickness (Gao et al. 2006). 


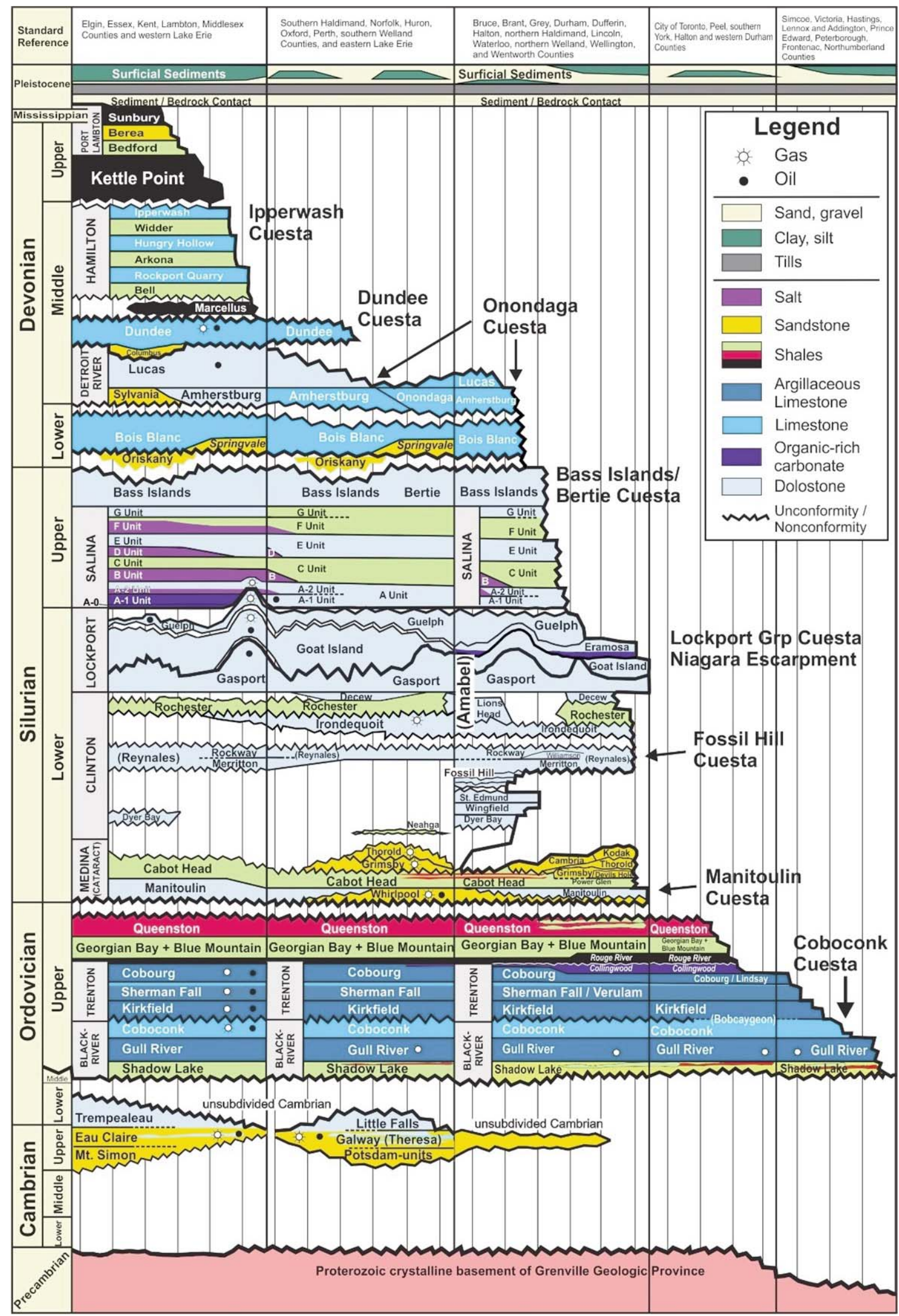

Figure 2. Subsurface Paleozoic stratigraphy of southern Ontario showing named geological formations, their geologic ages, positions of major unconformities (vertical hatch pattern), and principal oil and gas producing intervals (adapted from Carter et al. 2019). 


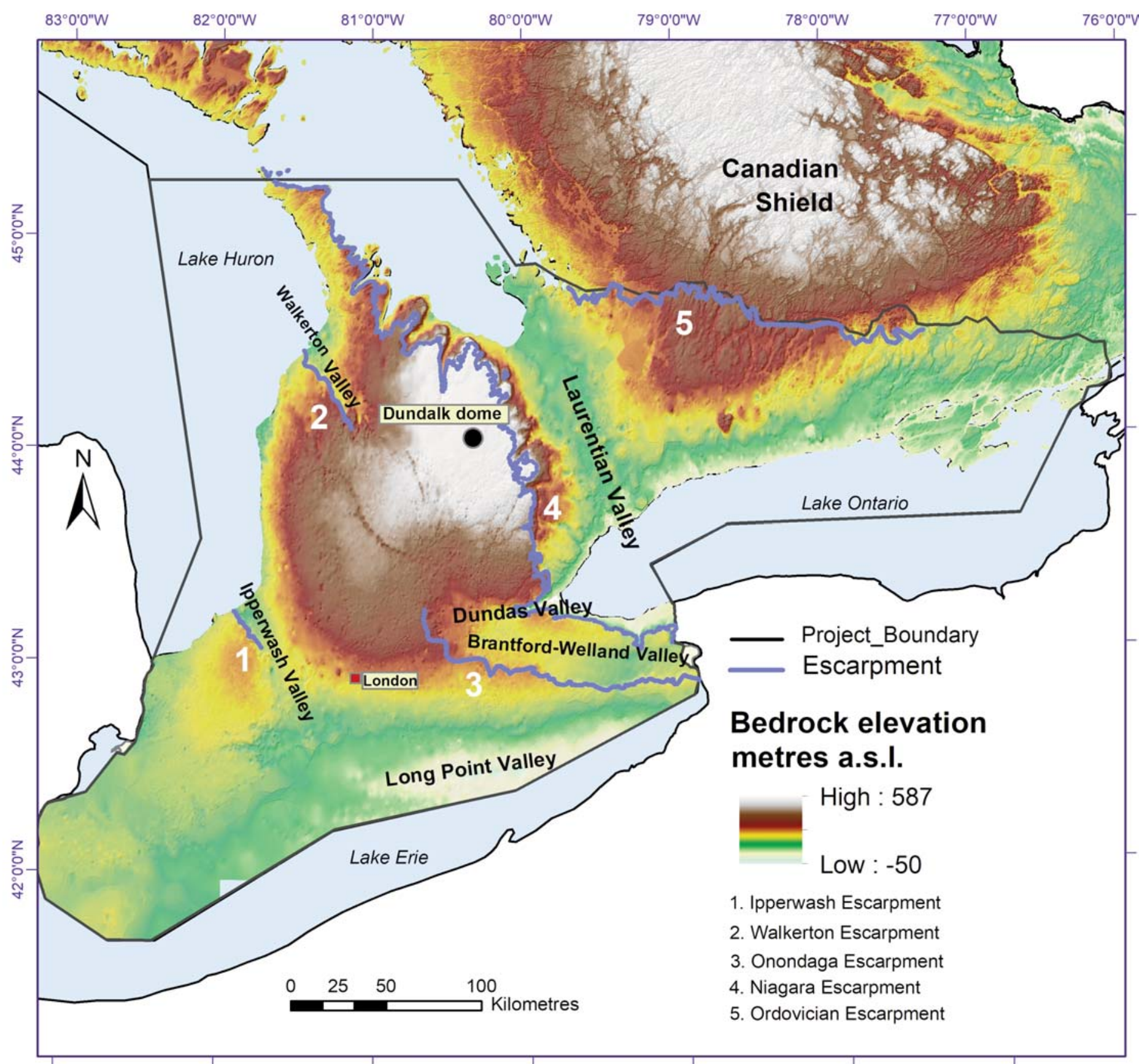

Figure 3. Topography of the bedrock surface in southern Ontario, showing principal named bedrock valleys and bedrock cuestas, derived from Gao et al. (2006), Gao (2011) and Brunton and Dodge (2008). Also shown is the Dundalk dome, a bedrock topographic high in the Lockport Group (Priebe and Brunton 2016; Priebe et al. 2021).

Lateral continuity is generally poor, with rapid lateral facies change. Sediments are thickest in bedrock valleys and beneath major moraines, and thinnest near escarpments, along river valleys and in the Bruce Peninsula (Logan et al. 2020). The ice sheets removed all older unconsolidated sediments and eroded the weathered surface of the bedrock. Estimates of the depths of glacial erosion vary but at least tens of metres and up to 200 $\mathrm{m}$ of Paleozoic bedrock was removed in most of the onshore portion of southern Ontario (Hallet 2011).

The bedrock surface reaches its highest elevation on the Dundalk dome, immediately west of the Niagara Escarpment
(Fig. 3). Regional slope of the bedrock surface is to the southwest on the western side of the Niagara Escarpment. East of the escarpment the bedrock surface slopes south and west from the highlands of the Canadian Shield into the Laurentian Valley and the Lake Ontario basin. Average regional slopes are approximately 1.5 to $3.2 \mathrm{~m} / \mathrm{km}$ in both areas, steepening on the sides of bedrock valleys, gorges, and cuestas. A system of glacially-sculpted buried valleys, narrow steep-walled gorges, and bedrock cuestas characterize the present-day bedrock surface (Fig. 3) (Gao 2011). The valleys coincide with the subcrop belts of easily eroded shale of the Hamilton Group, Georgian 
Bay Formation and Blue Mountain Formation, or evaporites of the Salina Group. Cuestas have formed on this deeply eroded surface by differential erosion of shale or evaporites undercutting erosion-resistant carbonate rocks along the up-dip edges of the shallow-dipping bedrock formations (Figs. 2, 3). The Niagara Escarpment is the most prominent example, with local relief exceeding $100 \mathrm{~m}$ (Figs. 1, 2). Topography of the bedrock surface exerts a controlling influence on water movement at the bedrock-overburden interface.

The Niagara Escarpment forms a significant topographic divide for surface and groundwater movement in southern Ontario. The dolostone cap-rocks forming the escarpment brow are significant sites for groundwater recharge due to stress-relief fracturing and karstification by meteoric water (e.g. Cowell 1976; Brunton and Brintnell 2020).

\section{Karst in Southern Ontario}

Large parts of southern Ontario are underlain by carbonate and evaporite bedrock. Following the Pleistocene glaciations there has been extensive karstic dissolution by acidic surface water where these rocks were exposed at or near the surface or in areas of thin overburden, and local reactivation of the paleokarst formed during earlier periods of exposure (Golder Associates Ltd. and Ontario Geological Survey 2008; Brunton and Dodge 2008; Brunton 2013). This is referred to as recent or modern karst in this study. Most shallow modern karst in southern Ontario has only limited depth of penetration of vertical conduits, probably due to erosional removal of the uppermost bedrock during Pleistocene glaciations and infill of karst openings with Quaternary sediments. Documented karst landform features in southern Ontario include karren, shallow caves, sinkholes, sinking streams and large springs. A much more complete description of the regional occurrence and geological relationships of shallow karst in southern Ontario and the history of its study is found in Brunton and Dodge (2008) and Brunton (2013), and for the Bruce Peninsula in Cowell (1976).

"Paleokarst", in the context of this study, is karst that formed in the geologic past during periods of subaerial exposure of carbonate and evaporite bedrock at major disconformities, with subsequent burial and preservation in the subsurface. These paleokarst horizons form regionally extensive intervals of enhanced porosity and permeability within the bedrock strata.

Mapping of modern karst in southern Ontario is compromised by the thick cover of surficial sediments, biasing visual identification of its distribution to areas of exposed bedrock (Brunton and Dodge 2008) (Fig. 4). Carter and Clark (2018) have identified large areas of inferred modern karst beneath surficial sediments using a GIS analysis of water well records from WWIS (Fig. 5). It includes the karst identified by Brunton and Dodge (2008), and also accurately delineates the "breathing well zone" in Huron County, a local karst aquifer in the Lucas Formation described by Freckelton (2012). Hamilton et al. (2017) have inferred the presence of large areas of karst beneath surficial sediments based on ratios of dissolved $\mathrm{CO}_{2}$ and $\mathrm{O}_{2}$ in shallow groundwater. Large areas of subcropping carbonate rocks in southern Ontario are identified as inferred or potential karst by Brunton and Dodge (2008) and Brunton (2013) based on their susceptibility to dissolution by meteoric and shallow groundwater. Modern karst has formed a complex shallow system of fresh groundwater, at depths from a few tens of metres to $200 \mathrm{~m}$ below the ground surface (Banks and Brunton 2017; Brunton et al. 2017; Priebe et al. 2019; Brunton and Brintnell 2020), the extent of which is still incompletely known.

At intermediate to deep depths within the bedrock, paleokarst horizons are the principal geological control on location of regional confined aquifers in the subsurface Paleozoic bedrock (Carter 2012; Carter and Fortner 2012; Sharpe et al. 2014). The most extensive paleokarst development is along disconformities at the top of the Lucas, Bass Islands, and Guelph formations and the unsubdivided Cambrian.

\section{Joints and Fractures}

At shallow depths there are ubiquitous regional stress-relief joints in the uppermost few metres of outcropping and subcropping bedrock especially near the edges of escarpments and bedrock gorges (e.g. Novakowski and Lapcevic 1988; Hancock and Engelder 1989; Eyles and Scheidegger 1995), which enhance permeability in the shallow bedrock (Fig. 6). Open vertical joints in subcropping carbonate strata may penetrate to several tens of metres as a result of solution widening and deepening. In the absence of karst, the apertures of vertical joints narrow rapidly with depth. At the Bruce site, in deeper bedrock, there is a dramatic decline in frequency of all types of fractures below $180 \mathrm{~m}$ depth (Intera Engineering Ltd. 2011).

\section{Faults}

Both normal faults and strike-slip faults have been identified in the bedrock of southern Ontario (Brigham 1971a, b; Armstrong and Carter 2010). The most prominent faults occur in the Chatham Sag. A fracture framework model developed by Sanford et al. (1985) indicated the Chatham Sag to be more fractured and faulted than the rest of southern Ontario. Maximum vertical displacement on normal faults is 50 to $100 \mathrm{~m}$ (Brigham 1971a, b; Carter 1991; Armstrong and Carter 2010). No recent analysis of the styles of faulting and timing of activity relative to regional orogenic events has been completed for southern Ontario.

Faults may form either barriers or pathways for lateral movement of groundwater in the subsurface. In the geologic past some of these faults have acted as pathways for vertical movement of groundwater across formation boundaries in southern Ontario, as indicated by dissolution, near faults, of subsurface salt beds in the Salina Group (e.g. Sanford 1977; Armstrong and Carter 2010). Collapse of younger strata over dissolution voids in subsurface salt beds can fracture the rocks, creating additional potential pathways for groundwater movement. Evidence of past movement of groundwater along a fault does not imply that the fault is currently a pathway for groundwater flow.

Preferential dolomitization of limestone of the Salina A-1 Carbonate and A-2 Carbonate has occurred along vertical 


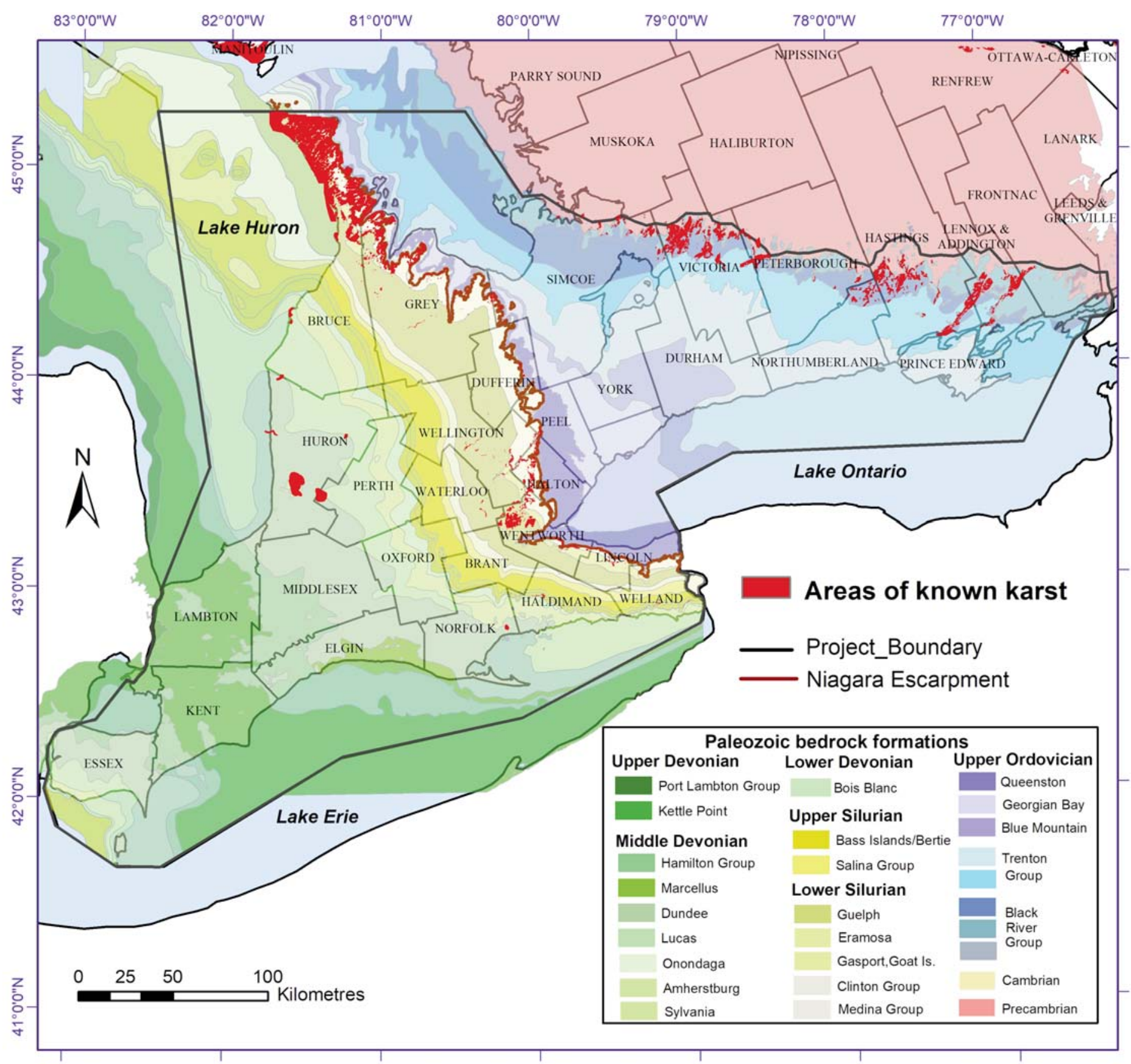

Figure 4. Areas of observed karst in southern Ontario, derived from Brunton and Dodge (2008). The limited mapped extent of karst reflects the masking effect of thick surficial sediments.

faults in Lambton County, presumably as a result of migration of formation water along the faults (Carter 1991). Reservoirs of natural gas occur in these dolomitized zones near the faults. Vertical cross-cutting "chimneys" of dolomite several hundred metres in width and several kilometres in length have formed in regional limestone units of the Trenton Group and Black River Group in Essex and Kent counties in association with vertical wrench faults (Middleton et al. 1993; Coniglio et al. 1994; Haeri-Ardakani 2013). Enhanced porosity and permeability in the dolomite have created reservoirs for crude oil and natural gas (e.g. Davies and Smith 2006, Dorland et al. 2016) and associated oil-field brine. There is no documentation of modern groundwater movement along faults in southern Ontario.

\section{METHODOLOGY AND DATASETS}

This study compiles and integrates a wealth of geological, hydrogeological, hydrochemical and isotopic data collected over the past 10 years by the authors and by others, to inform development of a high-level hydrostratigraphic framework for southern Ontario. 


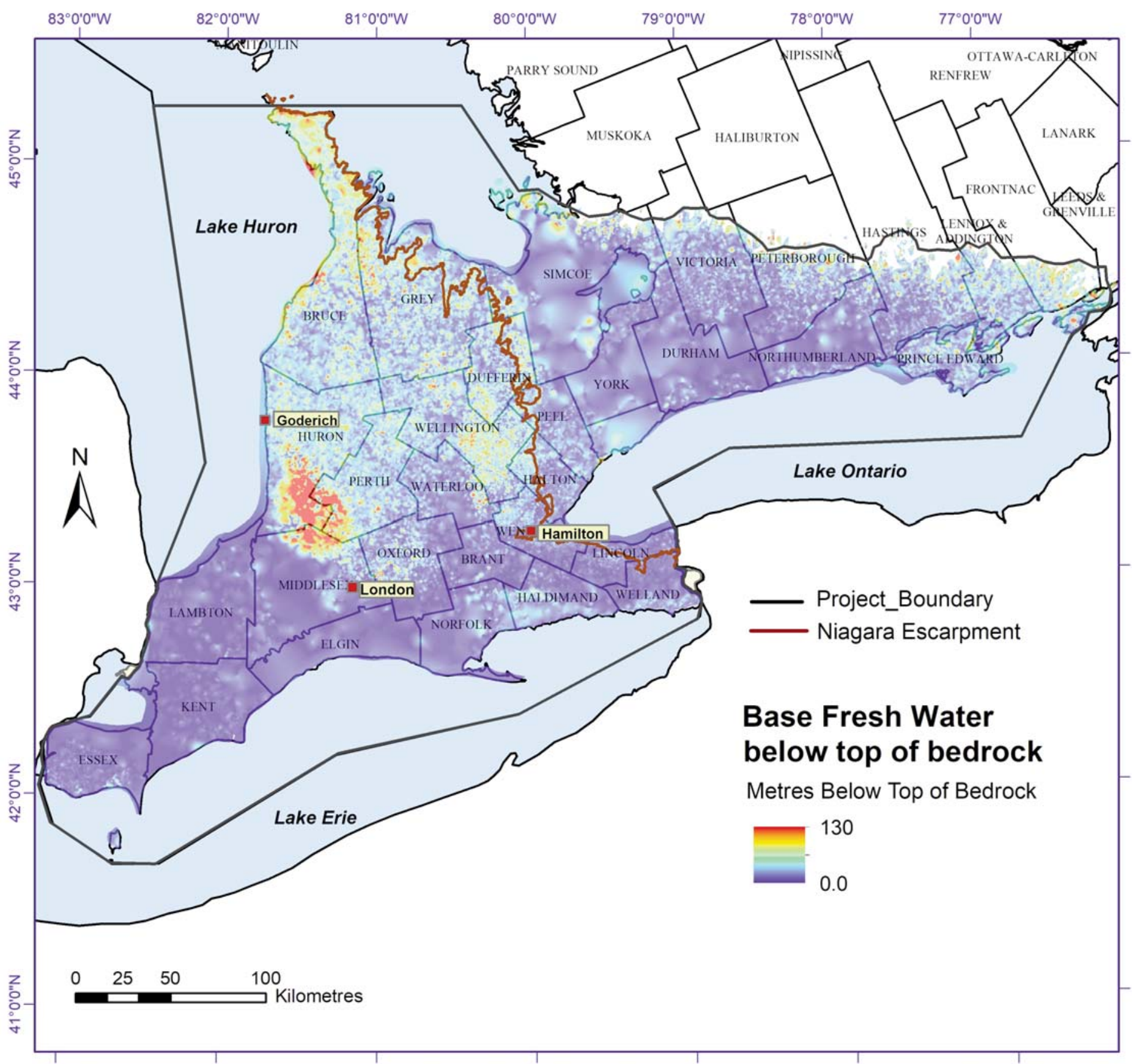

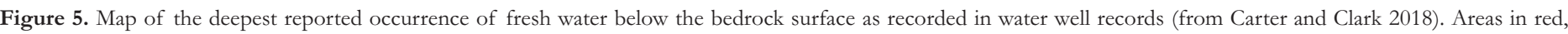

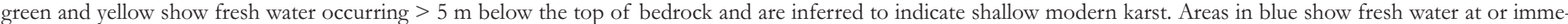

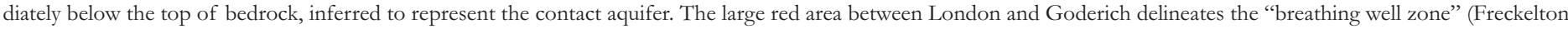

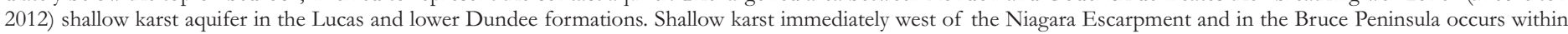
the Lockport Group.

The lithostratigraphy of southern Ontario is well-documented and recently updated (Brunton et al. 2017; Carter et al. 2017) and is the foundation for assignment of hydrostratigraphic units (HSU) using the concepts established by Maxey (1964). Unequivocal assignment of the complete thickness or geographic extent of individual lithostratigraphic units as an HSU is problematic in practice due to lateral and vertical inhomogeneity and anisotropy of formations due to facies changes, diagenesis, weathering and karstification, interbedded lithologies, etc. For the same reason there is no precise definition of aquifers or aquitards with respect to hydraulic conductivity. The terms aquifer and aquitard are used in a relative sense in this study, as recommended by Freeze and Cherry (1979). The water interval data from petroleum wells and the calculated probability of water occurrence within individual formations was a key criterion for identification of aquifers in the subsur- 

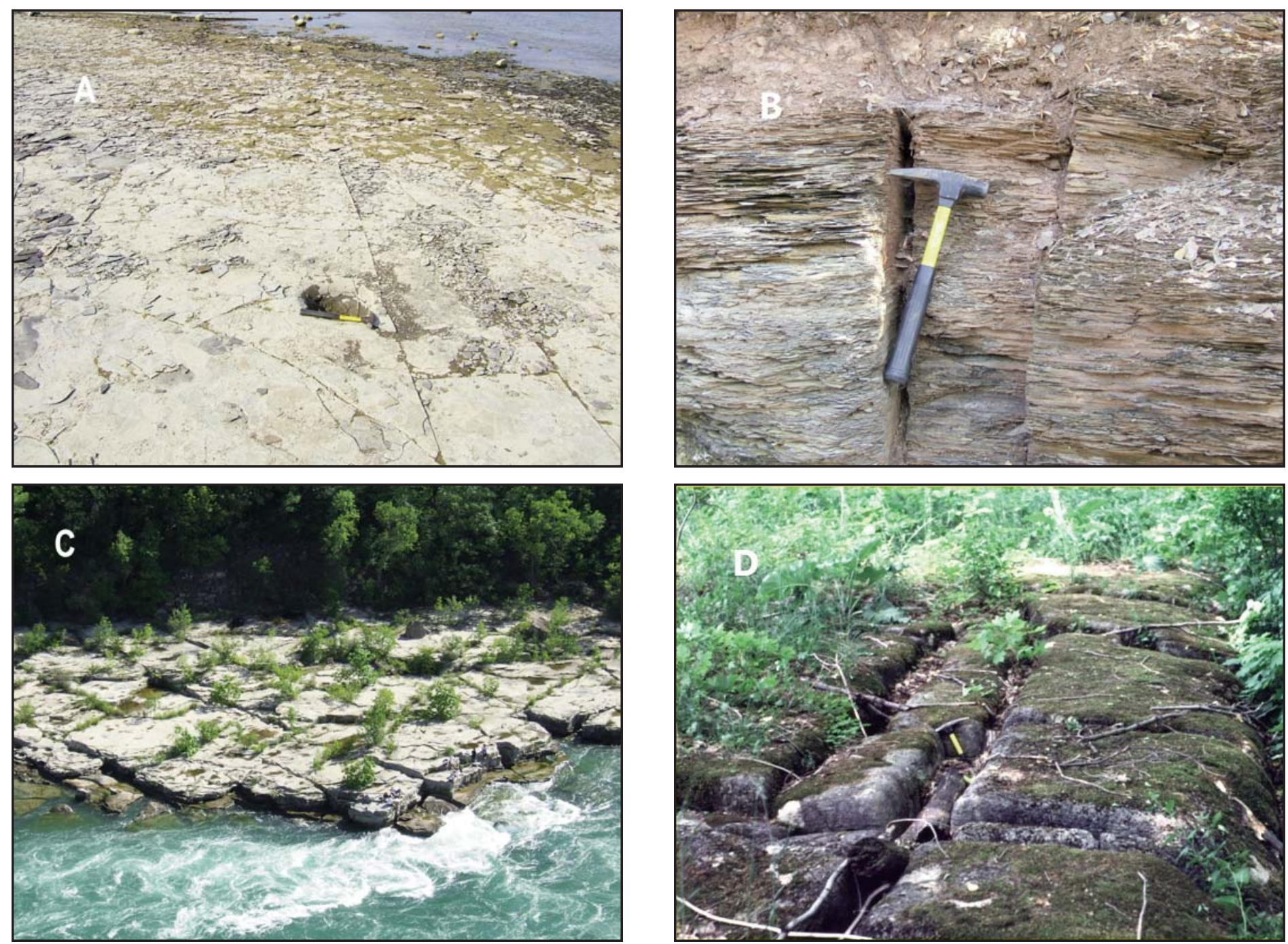

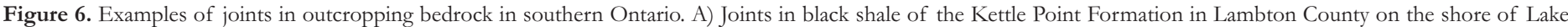

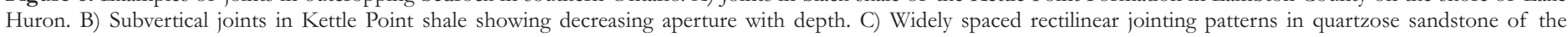
Whirpool Formation in the Niagara River. D) Solution widening of joints in Lockport Group dolostone in Bruce County.

face bedrock formations (see Table 1), together with the water interval maps of Carter et al. (2015a, b). In some instances, the available data do not allow an unequivocal assignment, in which case an interpretation has been made based on expert judgement and the weight of available data, subject to future revision. Water type varies with depth within individual aquifers and is not used to subdivide aquifers, but rather to define a regional hydrochemical depth zonation of groundwater within the aquifer systems.

Water interval records for petroleum wells are the principal data set used to identify regional groundwater intervals in the subsurface bedrock, and characterize bedrock formations as aquifers, aquitards or aquicludes. Specific to this study, bedrock formations intersected by petroleum wells drilled by the cable tool method, for which the driller has recorded the entry of water into the wellbore, are considered to be aquifers at the well location, regardless of the volume/flow, water type or commercial value of the water. The Ontario petroleum well database contains 35000 discrete records of water-bearing intervals within wellbores. Carter et al. (2015a) documented the geographic and stratigraphic occurrence of groundwater by water type, in each of the subsurface Paleozoic bedrock formations in southern Ontario. Carter et al. (2015b) constructed static level maps for the principal bedrock aquifers to interpret regional hydraulic gradients. The approximate base of sulphur water has been interpreted by Carter and Sutherland (2020) using a GIS analysis of petroleum well water interval records.

For this study, groundwater mapping by the Ontario Geological Survey (OGS) is the principal source of information on potable groundwater in the shallow bedrock of southern Ontario. This includes mapping of modern karst aquifers (e.g. Priebe et al. 2012, 2019, 2021; Priebe and Brunton 2016; Brunton et al. 2017; Brunton and Brintnell 2020), and characterization and mapping of the hydrochemistry of shallow groundwater (McIntosh et al. 2014; Hamilton 2015; Hamilton et al. 2015). The base of fresh water in southern Ontario was interpreted by Carter and Clark (2018) using a GIS query of WWIS (Fig. 5). 
Table 1. Water interval records from petroleum wells in southern Ontario documenting the number of wells that penetrate each geological formation, and the number of wells, by water type (see Table 2), for which a water interval is reported in the Ontario Petroleum Data System (OPDS). The water probability score represents the percentage of wells which encountered non-potable water and was a key criterion for designation of formations as either aquifers or aquitards. Reported fresh water intervals were excluded to eliminate both the effects of karstic dissolution at shallow depths, and fractured bedrock in the contact aquifer. The formations are in stratigraphic sequence from youngest to oldest, separated by geologic age with horizontal lines. See Carter et al. (2015a) for maps illustrating the geographical distribution of water intervals, coded by water type and formation.

\begin{tabular}{|c|c|c|c|c|c|c|c|c|c|c|c|}
\hline $\begin{array}{l}\text { Formation/ } \\
\text { Unit }\end{array}$ & \# Wells & $\begin{array}{l}\text { \# Water } \\
\text { Records }\end{array}$ & Black & Brackish & Fresh & $\begin{array}{l}\text { Lost } \\
\text { Circ. }\end{array}$ & Mineral & Salt & Sulphur & Unknown & $\begin{array}{c}\text { Water } \\
\text { Probability* }\end{array}$ \\
\hline Totals by type & & 34567 & 1797 & 112 & 14005 & 99 & 167 & 4670 & 12141 & 1576 & \\
\hline Surficial sediment & 18005 & 5387 & 18 & 6 & 5050 & 1 & 10 & 26 & 171 & 105 & \\
\hline Port Lambton & 132 & 27 & & & 23 & & & 1 & 2 & 1 & $3.0 \%$ \\
\hline Kettle Point & 4218 & 1027 & 4 & 1 & 958 & & & 14 & 27 & 23 & $1.6 \%$ \\
\hline Hamilton & 7719 & 944 & 3 & 2 & 636 & & 2 & 61 & 121 & 119 & $4.0 \%$ \\
\hline Dundee & 12079 & 4311 & 21 & 19 & 1648 & 1 & 23 & 392 & 2096 & 111 & $22.0 \%$ \\
\hline Columbus & 2350 & 607 & 18 & 2 & 24 & & 5 & 129 & 415 & 14 & $24.8 \%$ \\
\hline Lucas & 7236 & 3647 & 33 & 20 & 375 & 21 & 34 & 406 & 2640 & 118 & $45.2 \%$ \\
\hline Amherstburg & 7626 & 2276 & 86 & 5 & 1227 & 6 & 14 & 17 & 719 & 202 & $13.8 \%$ \\
\hline Sylvania & 1012 & 49 & 6 & & 7 & 1 & 3 & 1 & 28 & 3 & $4.2 \%$ \\
\hline Bois Blanc & 8997 & 1888 & 60 & 15 & 611 & 3 & 12 & 69 & 1058 & 60 & $14.2 \%$ \\
\hline Bass Islands & 12181 & 3047 & 385 & 8 & 757 & 22 & 18 & 161 & 1561 & 135 & $18.8 \%$ \\
\hline G Unit & 9149 & 143 & 3 & 1 & 48 & 2 & 1 & 11 & 75 & 2 & $1.0 \%$ \\
\hline F Unit & 8501 & 1487 & 126 & 2 & 757 & 4 & 6 & 25 & 480 & 87 & $8.6 \%$ \\
\hline F Salt & 1419 & 9 & 1 & & 1 & & & 3 & 2 & 2 & $0.6 \%$ \\
\hline E Unit & 8476 & 1308 & 109 & 3 & 660 & 3 & 3 & 20 & 432 & 78 & $7.6 \%$ \\
\hline D Unit & 3513 & 2 & & & 1 & 1 & & & & 0 & $0.0 \%$ \\
\hline C Unit & 8279 & 378 & 26 & & 173 & & 3 & 2 & 136 & 38 & $2.5 \%$ \\
\hline B Unit(B Marker) & 6457 & 467 & 37 & & 252 & 1 & 2 & 16 & 131 & 28 & $3.3 \%$ \\
\hline B Salt & 3257 & 11 & & & & & & 9 & 1 & 1 & $0.3 \%$ \\
\hline B Anhydrite & 4142 & 41 & 2 & & 19 & & & 1 & 15 & 4 & $0.5 \%$ \\
\hline A-2 Carbonate & 8542 & 604 & 23 & 2 & 144 & & 2 & 247 & 153 & 33 & $5.4 \%$ \\
\hline A-2 Shale & 3312 & 11 & & & 2 & & & 8 & 1 & 0 & $0.3 \%$ \\
\hline A-2 Anhydrite & 6573 & 20 & & & & & & 12 & 4 & 4 & $0.3 \%$ \\
\hline A-2 Salt & 2518 & 8 & & & & & & 8 & & 0 & $0.3 \%$ \\
\hline A-1 Carbonate & 7462 & 520 & 5 & 2 & 50 & 1 & 5 & 318 & 103 & 36 & $6.3 \%$ \\
\hline A-1 Evaporite & 3189 & 17 & & & & & & 16 & 1 & 0 & $0.5 \%$ \\
\hline Guelph & 15606 & 4903 & 805 & 14 & 394 & 4 & 19 & 1828 & 1657 & 182 & $28.9 \%$ \\
\hline Goat Island & 4213 & 151 & & & 3 & 1 & & 107 & 32 & 8 & $3.5 \%$ \\
\hline Gasport & 3765 & 148 & 1 & & 6 & 1 & & 110 & 26 & 4 & $3.8 \%$ \\
\hline Rochester & 12937 & 74 & 18 & & 3 & 1 & 2 & 20 & 21 & 9 & $0.5 \%$ \\
\hline Irondequoit & 9666 & 27 & 3 & & 5 & & & 15 & 1 & 3 & $0.2 \%$ \\
\hline RRMF**** & 4299 & 53 & 2 & & 8 & 1 & & 8 & 4 & 30 & $1.0 \%$ \\
\hline Thorold & 2726 & 13 & & & & & & 4 & & 9 & $0.5 \%$ \\
\hline Grimsby & 10172 & 42 & & & 1 & & & 19 & 4 & 18 & $0.4 \%$ \\
\hline Cabot Head & 10125 & 26 & & 1 & 11 & & & 10 & 3 & 1 & $0.1 \%$ \\
\hline Manitoulin & 2803 & 11 & & & 6 & & & 3 & 1 & 1 & $0.2 \%$ \\
\hline Whirlpool & 8409 & 40 & & 2 & 3 & & & 31 & 3 & 1 & $0.4 \%$ \\
\hline Queenston & 10253 & 97 & 1 & 3 & 73 & & 1 & 10 & & 9 & $0.2 \%$ \\
\hline \multicolumn{12}{|l|}{ Georgian Bay- } \\
\hline Blue Mountain & 1728 & 77 & & 2 & 39 & & & 22 & 6 & 8 & $2.2 \%$ \\
\hline Trenton** & 1857 & 58 & & & 10 & & 2 & 30 & 6 & 10 & $2.6 \%$ \\
\hline Cobourg & 1857 & 93 & 1 & & 7 & 1 & & 52 & & 32 & $4.6 \%$ \\
\hline Sherman Fall & 1225 & 54 & & & 2 & 3 & & 31 & 1 & 17 & $4.2 \%$ \\
\hline Kirkfield & 1001 & 32 & & & 3 & 2 & & 17 & & 10 & $2.9 \%$ \\
\hline Black River** & 999 & 16 & & & 2 & & & 11 & 1 & 2 & $1.4 \%$ \\
\hline Coboconk & 1205 & 51 & & & 2 & 6 & & 34 & 1 & 8 & $4.1 \%$ \\
\hline Gull River & 979 & 60 & & 2 & 2 & 9 & & 37 & 1 & 9 & $5.9 \%$ \\
\hline Shadow Lake & 1007 & 16 & & & 1 & 2 & & 12 & 1 & 0 & $1.5 \%$ \\
\hline Cambrian & 896 & 289 & & & 1 & 1 & & 286 & & 1 & $32.1 \%$ \\
\hline$* \%$ of wells that et & countered & water, wate & ype $\neq$ & Fresh & unsubdir & led & Reynales-P & kway-N & erriton-Fos & sil Hill & \\
\hline
\end{tabular}


Published hydraulic conductivity measurements were compiled for this study, as described below, and provide valuable data on flow rates of groundwater within bedrock formations. Published isotopic and hydrochemical data for groundwater in the bedrock were reviewed and supplemented with new data, to provide insights on groundwater types, source, history of evolution, and delineation of groundwater regimes.

Field visits were an important component contributing to geological understanding. All known sulphur water springs west of the Niagara Escarpment were visited and sampled. Quarries provided bedrock exposures facilitating direct observations of the relationships between groundwater flow and stratigraphy. More than 20 quarries west of the Niagara Escarpment were visited, including the McGregor Quarry in Essex County, the Port Dover Quarry in Norfolk County, the St. Marys Quarry in Perth County, the Bowmanville Quarry in Durham County, the Picton Quarry in Prince Edward County, the Guelph Dolime Quarry in Wellington County, all building stone quarries in Bruce County, the Sydenham Quarry in Grey County, the Pelee Island Quarry, the Beachville and Woodstock quarries in Oxford County, the Cayuga Quarry in Haldimand County, the Ridgemount Quarry in Welland County, and the Vineland Quarry and Beamer Quarry in Lincoln County.

\section{Well Databases}

Data are available primarily from one of two datasets, the Ministry of Environment, Conservation and Parks water well information system (WWIS) and the Ministry of Natural Resources and Forestry (MNRF) Ontario Petroleum Data System (OPDS) co-managed by the Oil Gas and Salt Resources Library (OGSRL; www.ogsrlibrary.com). WWIS is the principal source of regional data on shallow groundwater in southern Ontario (data.ontario.ca) with records for over 400000 water wells in southern Ontario, of which 160000 penetrate bedrock (Carter and Clark 2018). OPDS well records are the principal source of geological and hydrogeological information at deeper depths with records for nearly 27000 wells (Fig. 7).

\section{Water Type Data in the Ontario Petroleum Data System}

The water types reported from petroleum wells are subjective descriptions by drillers of groundwater encountered during drilling and are similar to the types recorded in the WWIS (Table 2). In OPDS, the geological formation within which the water is encountered is identified and recorded, using terminology consistent with Armstrong and Carter (2010).

In this study, description of water salinity uses the terminology of Carpenter (1978) and Freeze and Cherry (1979) (Table 3). The subjective water type identified as salt water (SAL) includes saline water and brine, with no odour of dissolved $\mathrm{H}_{2} \mathrm{~S}$. Sulphur water (SUL) is brackish to saline water that has an odour of dissolved $\mathrm{H}_{2} \mathrm{~S}$.

OPDS contains records for nearly 35000 water intervals (Table 1). Drillers record the depth at which water enters the well bore, the subjective water type, and the static level it stabilizes at within the wellbore before the zone is sealed off by casing. For the most part, only wells drilled by the cable tool method have water records as they are drilled in an open system with no hydraulic pressure, which allows groundwater to flow freely into the borehole.

\section{Isotopic and Hydrochemical Data}

Geochemical and isotopic characterization of deep groundwater in southern Ontario has been undertaken by several studies (McNutt et al. 1987; Dollar 1988; Dollar et al. 1991; Kaufman et al. 1993; Wilson and Long 1993; Weaver et al. 1995; Husain et al. 1998, 2004; Shouakar-Stash 2008). Skuce (2014) and Skuce et al. (2015a, b) acquired isotopic and geochemical fingerprints of 130 samples of intermediate to deep groundwater in southern Ontario in support of the current study. Most samples from intermediate to deep depths were obtained from active petroleum wells. Additional samples from shallow to intermediate depths were obtained from quarries, springs and artesian flow of water to the surface from orphan petroleum wells or deep water wells. Geochemical parameters analyzed included $\mathrm{Na}, \mathrm{Ca}, \mathrm{Mg}, \mathrm{K}, \mathrm{Si}, \mathrm{Sr}, \mathrm{Br}, \mathrm{Cl}, \mathrm{SO}_{4}, \mathrm{HCO}_{3}$, sulphide, and 24 trace elements. The oxygen and hydrogen isotope compositions of water $\left(\delta^{18} \mathrm{O}\right.$ and $\delta^{2} \mathrm{H}$, in \%o relative to Standard Mean Ocean Water - VSMOW) were also measured.

Petrophysical, hydrochemical and isotopic analyses of 1214 samples were obtained from eight deep diamond drill holes in the Paleozoic bedrock at the Bruce site (AECOM Canada Ltd. and Itasca Consulting Canada Inc. 2011; Hobbs et al. 2011; Intera Engineering Ltd. 2011; NWMO 2011; NWMO and AECOM Canada Ltd. 2011; Sykes et al. 2011). These studies included detailed depth profiles of stable isotopic ratios and hydrochemistry of groundwater and pore water in Paleozoic bedrock formations at the site.

As part of a regional ambient water chemistry survey, Hamilton (2015) collected over 900 samples of fresh water from domestic water wells completed in surficial sediments and in shallow bedrock at the interface with the sediments. Samples were analysed for a large suite of parameters, dissolved gases, major ions, trace elements, and stable isotopes of water. An additional 106 samples of fresh water were obtained from water wells completed in a shallow karst aquifer in the Lucas Formation in Huron County (Freckelton 2012).

\section{Hydraulic Conductivity}

Hydraulic conductivity measurements have been published for scattered locations in southern Ontario and have been compiled for this study (Table 4) (Novakowski and Lapcevic 1988; Intera Technologies Ltd. 1988; Raven et al. 1990, 1992; Weaver 1994; Golder Associates Ltd. 2003; Intera Engineering Ltd. 2011; Sykes et al. 2011; Beauheim et al. 2014; Priebe et al. 2017). Formations with relatively higher hydraulic conductivity correlate very well with observations of water-bearing intervals in petroleum wells.

Minimum and maximum values for individual formations can vary by several orders of magnitude at the same site. Such variation can be caused by variations in lithology, diagenesis, facies changes, and karst. Most of these measurements were acquired at shallow depths, less than $200 \mathrm{~m}$ below the surface. 


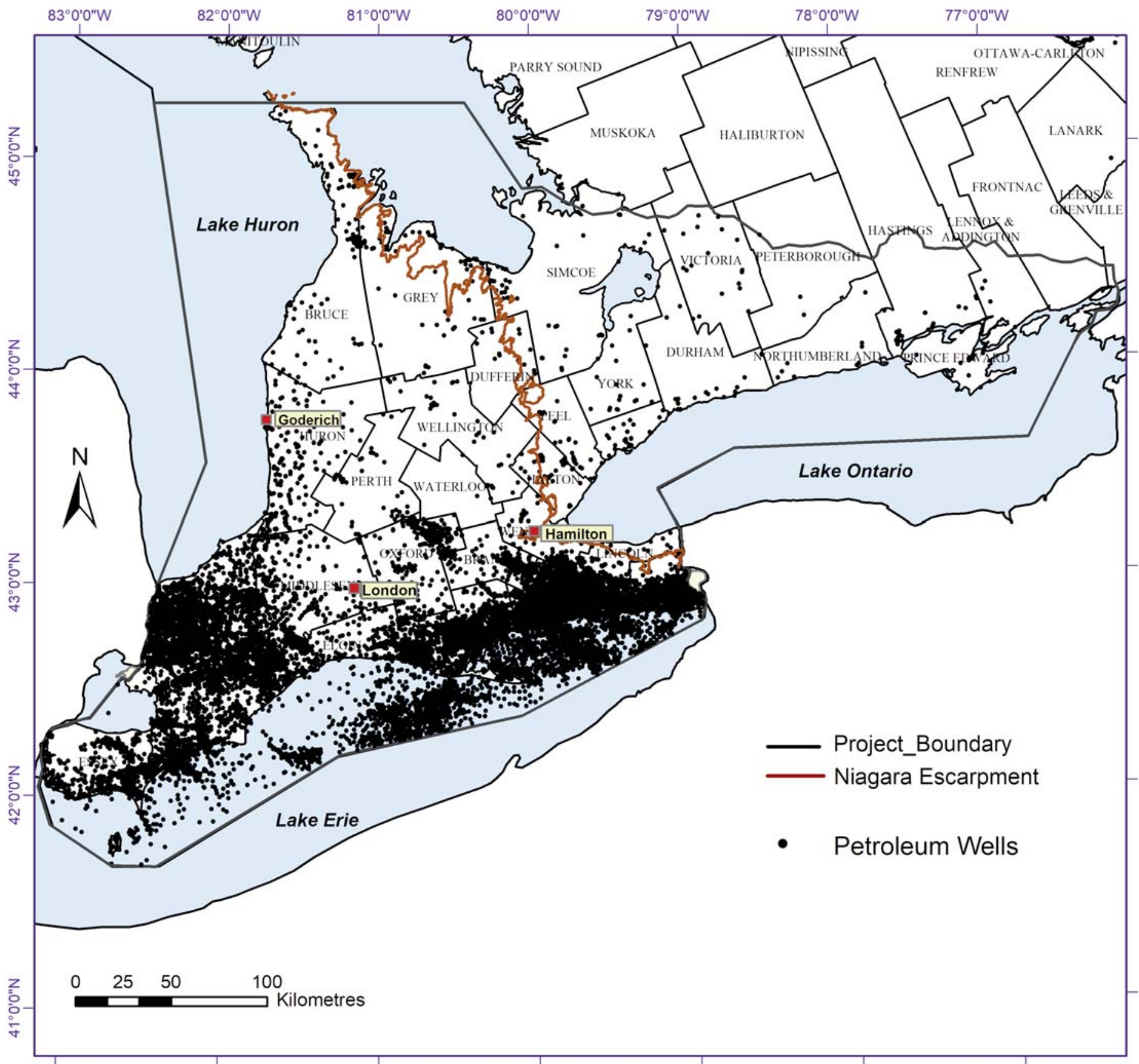

Figure 7. Locations of petroleum wells drilled in southern Ontario showing highly variable well density.

Table 2. Ontario Petroleum Data System (OPDS) water type codes and descriptions.

\begin{tabular}{ll}
\hline \hline Water Type Code & Description \\
\hline BLK & Black \\
BRA & Brackish \\
FRE & Fresh \\
LOS & Loss of circulation \\
MIN & Mineral \\
SAL & Salt \\
SUL & Sulphur \\
\hline
\end{tabular}

Table 3. Water types classified by salinity, as per Carpenter (1978) and Freeze and Cherry (1979).

\begin{tabular}{ll}
\hline \hline Water Type & $\mathbf{m g} / \mathbf{L}$ TDS \\
\hline Fresh & $0-1000$ \\
Brackish & $1000-10000$ \\
Saline & $10000-100000$ \\
Brine & $>100000$ \\
\hline
\end{tabular}


Table 4. Hydrostratigraphic units defined in this study, with hydraulic conductivity values and source reference: (a) Priebe et al. 2017; (b) Novakowski and Lapcevic 1988; (c) Intera Technologies Ltd. 1988; (d) Golder Associates Ltd. 2003; (e) Intera Engineering Ltd. 2011, Beauheim et al. 2014; (f) Weaver 1994; (g) Raven et al. 1990, 1992; (h) Sykes et al. 2011; (i) Freeze and Cherry 1979.

\begin{tabular}{|c|c|c|c|c|}
\hline Hydrostratigraphic Unit & Included Formations & Water Type & $\begin{array}{l}\text { Hydraulic } \\
\text { Conductivity } \mathrm{m} / \mathrm{s}\end{array}$ & Reference \\
\hline HSU 1. Surficial Sediment System & Glacial and modern sediments & fresh & $10^{-1}$ to $10^{-12}$ & $\mathrm{i}$ \\
\hline HSU 2. Contact Aquifer & Interface of surficial sediments $\&$ bedrock & fresh, brackish & $1 \times 10^{-5}$ & g \\
\hline HSU 3. Shallow Karst Aquifer System & Carbonate bedrock subcrop/outcrop & fresh & $5 \times 10^{-3}$ to $6 \times 10^{-7}$ & $a, b, e, g$ \\
\hline HSU 4. Devonian Aquitard & $\begin{array}{l}\text { Port Lambton Group, Kettle Point, } \\
\text { Hamilton Group, Marcellus, upper Dundee }\end{array}$ & nil & $1 \times 10^{-7}$ to $4 \times 10^{-13}$ & $c, f, g$ \\
\hline HSU 5. Lucas-Dundee Aquifer & lower Dundee, Lucas & sulphur, brackish, saline & $1 \times 10^{-6}$ to $8.4 \times 10^{-8}$ & $c, f, g, h$ \\
\hline HSU 6. Amherstburg-Bois Blanc Aquitard & $\begin{array}{l}\text { Amherstburg, Bois Blanc, Springvale, } \\
\text { Sylvania, Onondaga }\end{array}$ & nil & $1 \times 10^{-6}$ to $3.2 \times 10^{-11}$ & $c, e, g$ \\
\hline HSU 7. Bass Islands Aquifer & Bass Islands, Bertie, Oriskany & sulphur, saline, brackish & $1 \times 10^{-4}$ to $1 \times 10^{-7}$ & $c, e, h$ \\
\hline HSU 8. Salina Aquitard & Salina Group & nil & $3 \times 10^{-10}$ to $5 \times 10^{-14}$ & e \\
\hline HSU 9. Guelph Aquifer & Guelph & brine, sulphur & $2.8 \times 10^{-4}$ to $7.9 \times 10^{-9}$ & $e, g$ \\
\hline HSU 10. Lower Lockport Aquitard & Eramosa, Goat Island, Gasport & nil & $4 \times 10^{-8}$ to $2 \times 10^{-12}$ & $a, b, g$ \\
\hline HSU 11. Clinton-Medina Aquitard & Clinton Group, Medina Group & nil & $5 \times 10^{-12}$ to $9 \times 10^{-14}$ & $\mathrm{~b}, \mathrm{e}, \mathrm{g}$ \\
\hline HSU 12. Ordovician Shale Aquiclude & Queenston, Georgian Bay, Blue Mountain & nil & $1 \times 10^{-8}$ to $3 \times 10^{-14}$ & $\mathrm{~b}, \mathrm{e}, \mathrm{g}$ \\
\hline HSU 13. Trenton-Black River Aquitard & Trenton Group, Black River Group & nil & $1 \times 10^{-11}$ to $4 \times 10^{-15}$ & $c, d, e, g, h$ \\
\hline HSU 14. Cambrian Aquifer & All Cambrian formations & brine & $3 \times 10^{-6}$ to $1 \times 10^{-9}$ & e \\
\hline HSU 15. Precambrian Aquitard & Precambrian & nil & $1 \times 10^{-9}$ to $1 \times 10^{-12}$ & $\mathrm{e}$ \\
\hline
\end{tabular}

At these depths much of the bedrock has been affected by infiltration of meteoric water, with enhancement of porosity and permeability in carbonate and evaporite bedrock by karstic dissolution. At the Bruce site high quality permeability data from the complete Paleozoic stratigraphic sequence was obtained from a total of 88 test intervals for six deep boreholes (Intera Engineering Ltd. 2011; Beauheim et al. 2014). The Bruce dataset is unique in Ontario for the amount and vertical continuity of data available at a single site, and for the depth at which most of the data was obtained, well below the effects of modern or glacial groundwaters.

\section{HYDROCHEMICAL GROUNDWATER REGIMES AND HYDROGEOLOGICAL MODEL}

The aquifer and aquitard systems of southern Ontario are developed within a superimposed hydrochemical regime, with zonation by depth consistent with the progression documented by Chebotarev (1955), Sykes et al. (2011), McIntosh and Walter (2006) and Hobbs et al. (2011). A similar hydrochemical depth zonation in sedimentary bedrock in the United States was reported by Stanton et al. (2017). Three groundwater hydrochemical regimes can be recognized in southern Ontario:

1. A shallow water regime of predominantly bicarbonate-rich fresh water occurs in the unconsolidated glacial and recent sediments and shallow bedrock to a depth of approximately 100 to $250 \mathrm{~m}$ beneath the surface.

2. An intermediate water regime of brackish to saline sulphur and sulphate-rich water occurs beneath the shallow zone to a maximum depth of approximately 350 to $400 \mathrm{~m}$.
3. A deep water regime of ancient water, dominated by dense $\mathrm{Na}-\mathrm{Cl}$ and $\mathrm{Ca}-\mathrm{Na}-\mathrm{Cl}$ brine, occurs in the deep bedrock extending to the Precambrian rocks of the Canadian Shield that underlie Paleozoic cover.

Depths of the water regimes vary geographically, influenced by the geomorphology, surficial geology, and outcropping or subcropping bedrock geology. Where shale outcrops or subcrops, brackish to saline water is present within a few metres of the bedrock surface and fresh water is largely confined to the surficial sediments and the interface between the sediments and the bedrock (see Fig. 5). In areas of shallow modern karst, fresh water of the shallow water regime has penetrated much deeper into the bedrock.

A revised and updated hydrogeological model is presented here (Fig. 8). Most of the confined aquifers at shallow to intermediate depths in the bedrock are recharged by meteoric water through shallow modern karst at their outcrop and subcrop edges, with down-dip hydraulic gradients along formation contacts. The depth of penetration of meteoric water depends on the permeability of the formation, including the degree of karstification, the lateral continuity of the permeable horizon, the hydraulic gradient, and the buoyancy effects of saline water and brine in the deeper bedrock formations. Hydrochemistry and $\delta^{18} \mathrm{O}$ and $\delta^{2} \mathrm{H}$ compositions suggest the original pre-Pleistocene groundwaters in the intermediate regime have mixed with and largely been replaced by both modern and cooler climate fresh waters, probably as a result of enhanced fluid flow and recharge beneath the LIS during the last glacial maximum (Bense and Person 2008; McIntosh et al. 2011), as discussed below. These waters have subsequently been altered by 


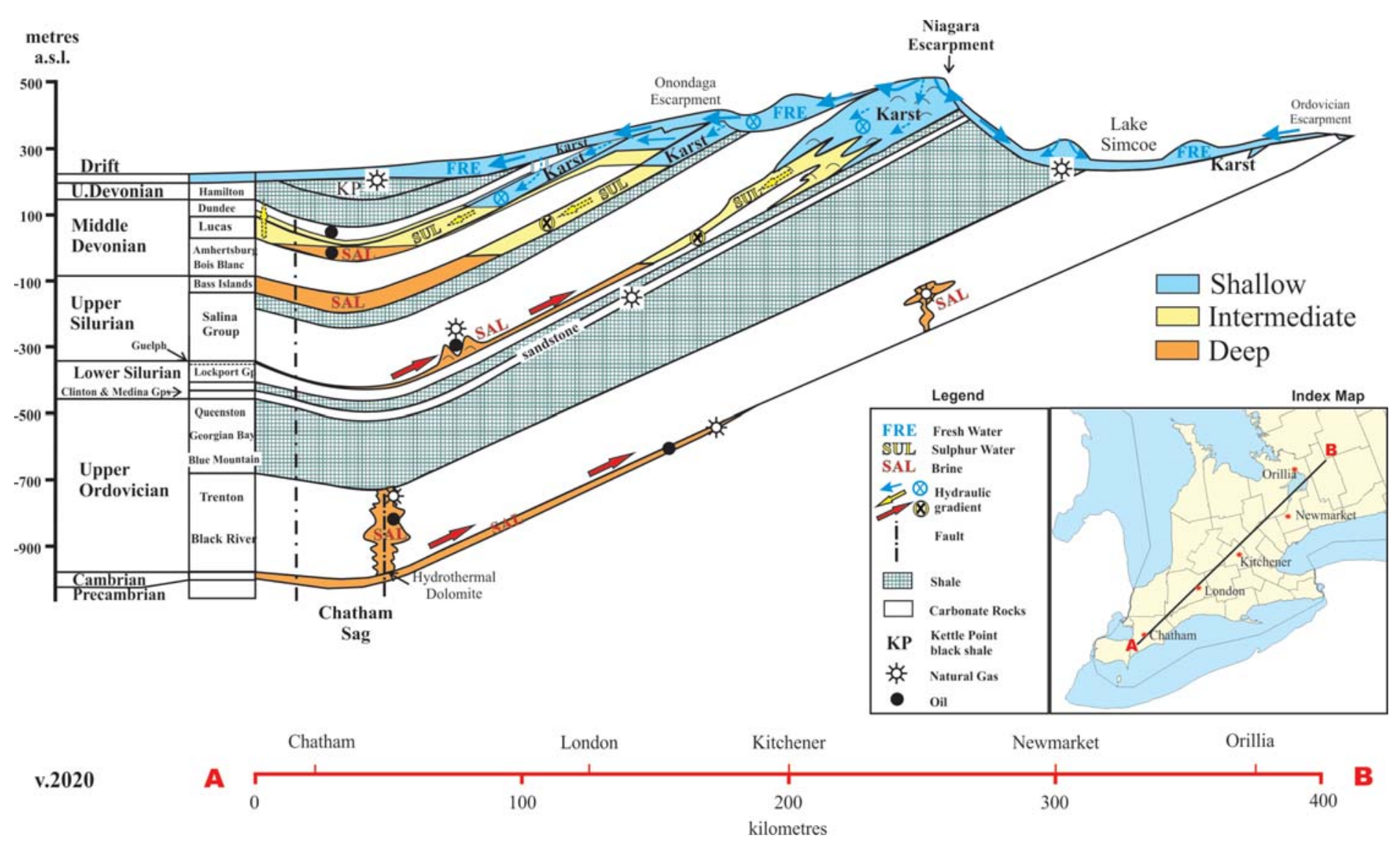

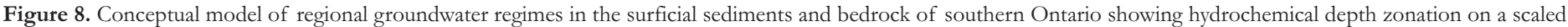

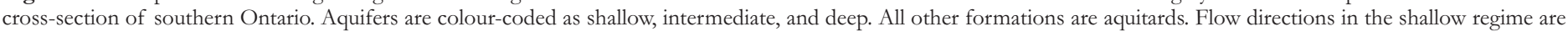

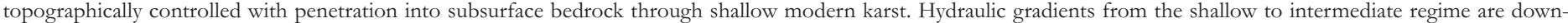
dip along bedrock paleokarst horizons with only limited active recharge and discharge, and up-dip in the deep brine regime, with no active recharge or discharge.

water-rock interactions and biochemical processes, also discussed below.

\section{Shallow Groundwater Regime}

Within the shallow groundwater regime three distinct hydrogeological systems are recognized and designated as hydrostratigraphic units: surficial sediment aquifer-aquitard system, contact aquifer, and shallow karst aquifer. These groundwater systems correspond to the three shallow systems of Sharpe et al. (2014) and are described in more detail below. All domestic water wells in southern Ontario acquire potable groundwater from the shallow groundwater regime.

Flow directions in the shallow groundwater regime above the bedrock-overburden interface are principally down-gradient from topographic highs (Sharpe et al. 2014). Shallow modern karst is the entry point for groundwater penetration into subsurface bedrock, within which regional hydraulic gradients are down the regional dip of porous bedrock formations (Fig. 8).

The deepest reported occurrence of fresh water in water well records is $130 \mathrm{~m}$ below the top of bedrock (Fig. 5) and approximately $175 \mathrm{~m}$ below the ground surface. Fresh water is reported in petroleum well records at depths of up to $250 \mathrm{~m}$ below the surface, approximately $200 \mathrm{~m}$ below top of bedrock (Carter and Clark 2018). The variability in the reported depth to the base of fresh water largely reflects the practice of water well drillers to terminate drilling at the shallowest interval from which a fresh water supply can be obtained. Therefore, it is expected that the actual depth to the base of fresh water, at least locally, may be significantly greater than documented in water well records.

Groundwater in the shallow regime is generally fresh and is locally brackish to sulphurous. Water composition is dominated by $\mathrm{Ca}-\mathrm{HCO}_{3}$ and $\mathrm{Ca}-\mathrm{SO}_{4}$, with $\mathrm{pH}$ values ranging from 6.2 to 8.8 , and a total dissolved solids (TDS) content averaging 770 $\mathrm{mg} / \mathrm{L}$ (calculated from Hamilton 2015). In a regional shallow groundwater characterization study covering all southern Ontario, the $\delta^{18} \mathrm{O}$ and $\delta^{2} \mathrm{H}$ compositions of fresh groundwater were determined by Hamilton et al. (2015) for 596 samples from water wells finished at shallow depths into bedrock or at the bedrock-sediment interface. All samples plot on the local meteoric water line for Simcoe, Ontario. The $\delta^{18} \mathrm{O}$ values of most of these samples range from -13 to $-10 \%$, similar to modern meteoric-sourced groundwater, with a secondary modal peak at $-17 \%$ which was interpreted as glacial meltwater. 

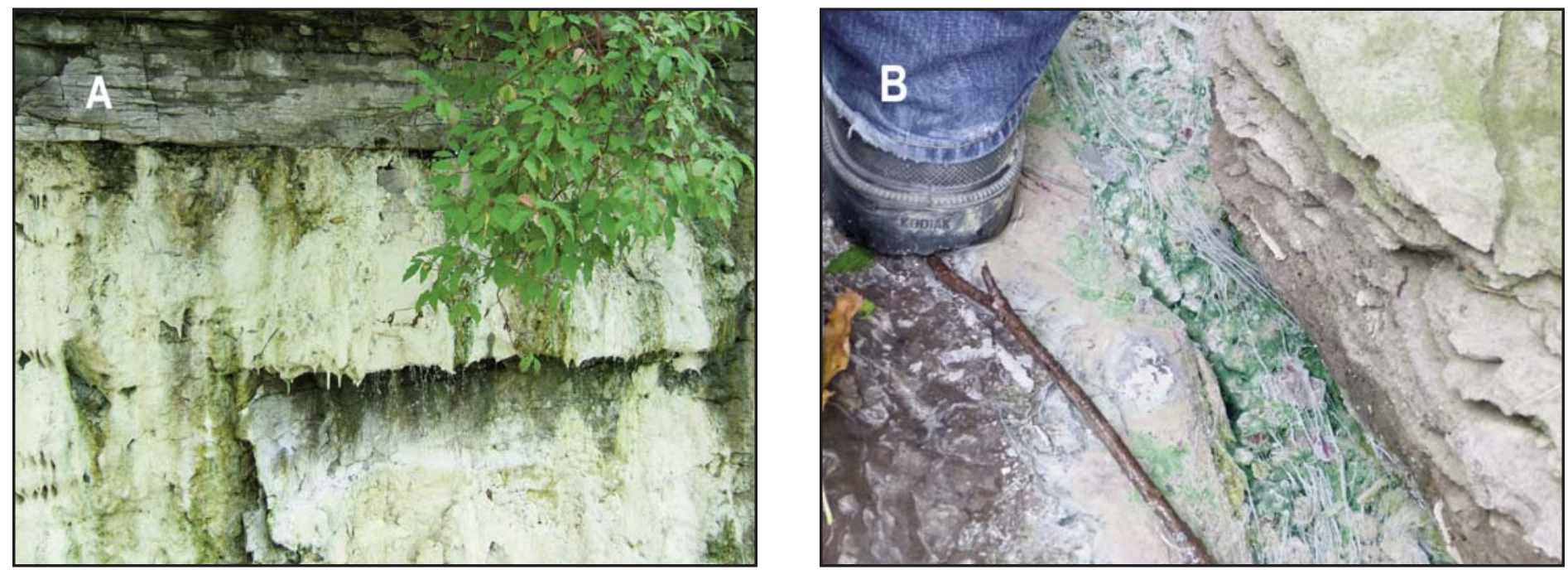

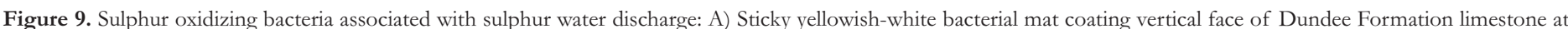

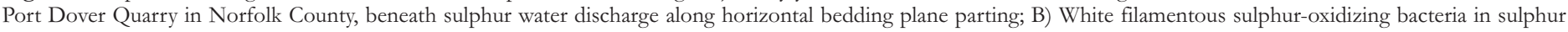
water spring at contact of Dundee Formation with underlying Onondaga Formation at Hemlock Creek in Norfolk County. Heel of boot is 8 cm wide.

\section{Intermediate Brackish-to-Saline Sulphur Water Regime}

Brackish to saline sulphur water (water containing dissolved $\mathrm{H}_{2} \mathrm{~S}$ ) is ubiquitous at intermediate depths varying from a few tens of metres to a maximum of $350 \mathrm{~m}$ below ground level (Carter and Sutherland 2020). It occurs in all formations but is particularly prominent in regional bedrock aquifers in the Lucas and lower Dundee, the Bass Islands, and the Guelph formations (Carter et al. 2015a). The deepest occurrence of sulphur water is in areas of modern post-glacial karst where the fresh water regime is also deepest. Hydraulic gradients are down the regional dip of bedrock formations. Sulphur water from the Lucas and lower Dundee formations discharges to the surface in topographic lows at several locations in southern Ontario, including springs, water wells, unplugged petroleum wells, and as seeps in the floor and walls of quarries, indicating a locally active flow system. Regional flow direction is from northeast to southwest, down the regional dip of the bedrock formations.

Groundwater studies in the Midwest Basins and Arches Aquifer System in parts of Indiana, Ohio, Michigan, and Illinois indicate as little as $2 \%$ of the shallow fresh groundwater enters the bedrock aquifer system (Eberts and George 2000). Comparable estimates for southern Ontario have not been made but the limited number of known sulphur water discharge sites, with their distinctive and easily detected olfactory signature, suggests that active recharge from the shallow water regime is limited.

Where sulphur water flows to the surface the discharged water is often populated by white filamentous colonies of sulphur-oxidizing proteobacteria and/or sticky yellow bacterial films and mats (Fig. 9) and has a foul rotten-egg odour indicating the presence of dissolved $\mathrm{H}_{2} \mathrm{~S}$. Dissolved $\mathrm{H}_{2} \mathrm{~S}$ is a diagnostic field indicator of the presence of sulphate-reducing delta proteobacteria in the groundwater (Dyer 2003). These bacteria utilize oxygen from dissolved sulphate to oxidize organic matter under anoxic conditions, with $\mathrm{H}_{2} \mathrm{~S}$ released as a waste prod- uct. Microbial DNA analyses of sulphur water samples collected by the first author from the lower Dundee Formation in Norfolk County show abundant and diverse microbial populations dominated by sulphur proteobacteria (J. Neufeld personal communication 2015).

Similar microbial communities were reported by Ruberg et al. (2008) on the floor of Lake Huron near Middle Island in Michigan, where springs of sulphur water from a regional aquifer in the Detroit River Group fill a submerged karst sinkhole. They report long white strands of sulphur oxidizing bacteria and purple microbial mats coating the walls and floor of the sinkhole. The groundwater entering the sinkhole had an average temperature of 10 to $12^{\circ} \mathrm{C}$, with elevated concentrations of chlorides, sulphates, and bacteria relative to lake water.

Groundwater in the intermediate regime has $\mathrm{pH}$ of 7.2 to 11.7 and is brackish to saline (563 to $43600 \mathrm{mg} / \mathrm{L}$ TDS). Its composition ranges from $\mathrm{Ca}-\mathrm{SO}_{4}$ to $\mathrm{Na}-\mathrm{Ca}-\mathrm{Cl}$ to $\mathrm{Ca}-\mathrm{Na}-\mathrm{Cl}$ with generally elevated levels of sulphate relative to the deep brine regime, and generally low levels of other dissolved elements. Isotope ratios of oxygen and sulphur in the dissolved sulphate in samples analyzed by Skuce (2014) range from +12.2 to $+53.9 \%{ }_{0}^{34} \mathrm{~S}_{\mathrm{SO} 4}$ and +8.7 to $+19.9 \%{ }^{18} \mathrm{O}_{\mathrm{SO} 4}$, and are consistent with an origin from dissolution of evaporite minerals (anhydrite, gypsum) in the bedrock formations (Skuce 2014; Skuce et al. 2015a, b). They also confirm that bacterially mediated dissimilatory sulphate reduction is active in the shallow groundwater systems (Skuce 2014). The oxygen and hydrogen isotope compositions for the water plot close to the Global Meteoric Water Line of Craig (1961) with values ranging from those typical of modern precipitation in the study area to those more characteristic of Pleistocene glacial meltwater (Skuce 2014; Skuce et al. 2015a, b).

\section{Deep Brine Regime}

The confined aquifers in the deep regime contain dense brines with $\mathrm{pH}$ values from 3 to 7 , and measured salinities from 
138000 to $441000 \mathrm{mg} / \mathrm{L}$ TDS, dominated by sodium and calcium chlorides (Dollar et al. 1991; Hobbs et al. 2011; Skuce 2014; Skuce et al. 2015a, b).

The depth at which the brine system occurs depends on the presence or absence of aquitards in the overlying bedrock and distance down-dip from subcrop. In areas where shale comprises the uppermost bedrock there is very shallow penetration of fresh water and the brine system begins at depths as shallow as $200 \mathrm{~m}$, as confirmed by hydrochemical analyses of formation water (Skuce 2014; Skuce et al. 2015b). In areas of modern shallow karst, petroleum well records indicate that the brine regime does not begin until a depth of $350 \mathrm{~m}$ below the ground surface. At depths of $>350$ to $450 \mathrm{~m}$ petroleum well records indicate that all groundwater in the Paleozoic bedrock is brine. This is corroborated at the Bruce site by analyses of pore water extracted from crushed drill core which show increasing salinity to depths of 350 to $400 \mathrm{~m}$ below which a $\mathrm{Na}-\mathrm{Cl}$ basinal brine exists (Intera Engineering Ltd. 2011). This water is often referred to as formation water.

The $\delta^{18} \mathrm{O}$ and $\delta^{2} \mathrm{H}$ of the deep brines (Dollar 1988; Dollar et al. 1991; Weaver 1994; Skuce 2014; Skuce et al. 2015a) plot well to the right of the Global Meteoric Water Line of Craig (1961) with unique isotopic compositions for different aquifers having developed over extended periods of geologic time. The isotopic compositions are typical of sedimentary basin brines formed by evaporative concentration of seawater (Holser 1979; Knauth and Beeunas 1986) in a sabkha or salina depositional environment, such as that under which deposition of the Salina Group and Lucas Formation occurred. Such an origin is also consistent with the extremely high salinities.

Flow model simulations (Sykes et al. 2011) indicate that brines have been trapped in these rocks for millions of years. Clark et al. (2013) have calculated a residence time of at least 260 million years for brine trapped as pore water within the Ordovician shale units.

Static level maps prepared using OPDS water interval data indicate up-dip hydraulic gradients for brine in the Guelph Formation and Cambrian units (Carter et al. 2015b) similar to calculated gradients at the Bruce site (Intera Engineering Ltd. 2011). There is no known natural discharge of deep brines to the surface.

\section{EFFECTS OF GLACIATION ON GROUNDWATER}

Glaciation of North America had a profound effect on groundwater systems. Greatly increased hydraulic gradients would have been produced by pressurized subglacial meltwater beneath the LIS, resulting in deep penetration of fresh water into porous and permeable bedrock formations, flushing out and/or diluting the original formation waters. Glacial meltwater can be identified by low $\delta^{18} \mathrm{O}$ and $\delta^{2} \mathrm{H}$. Glacial meltwater $\delta^{18} \mathrm{O}$ values compiled by McIntosh and Walter (2006) for Michigan, northern Indiana/Ohio and southern Ontario range from -25 to $-11 \%$, and an average $\delta^{18} \mathrm{O}$ of $-25.4 \pm 2.5 \%$ is commonly ascribed to the LIS (Ferguson and Jasechko 2015).

Isotopic evidence has been cited to indicate the presence of meteoric water of likely glacial origin in clay-rich glacial sediments (Desaulniers et al. 1981; Aravena at al. 1995), in the con- tact aquifer (Husein et al. 2004; Skuce 2014; Hamilton et al. 2015), and in the intermediate groundwater regime (Dollar 1988; Skuce 2014; Skuce et al. 2015a). At the Bruce site, at a depth of $340 \mathrm{~m}$, saline pore water from a 4-m thick paleokarst interval in the uppermost Salina A-1 Carbonate Unit had isotopic compositions of $\delta^{18} \mathrm{O}=-14.4 \%$ and $\delta^{2} \mathrm{H}=-104 \% 0$ (Intera Engineering Ltd. 2011), suggestive of glacial meltwater. A sub-regional sulphur water interval at the top of the A-1 Carbonate identified by Carter and Sutherland (2020) extending east to the subcrop belt is the likely pathway for down-dip penetration of glacial meltwater, a distance of $25 \mathrm{~km}$.

Sulphur water samples from the lower Dundee Formation, immediately east of the pinch-out edge of the Lucas Formation in Norfolk County, were obtained from seepage into the Port Dover Quarry, within the subcrop belt, and from four unplugged petroleum wells exhibiting artesian flow at the surface in the valleys of Big Creek and Big Otter Creek in Norfolk County, at successively deeper depths down-dip from the subcrop. The $\delta^{18} \mathrm{O}$ and $\delta^{2} \mathrm{H}$ of the groundwater decrease progressively down-dip and with increasing depth (from 10 to $83 \mathrm{~m}$ below ground surface) from -7.8 to $-14.8 \%$ for $\delta^{18} \mathrm{O}$ and from -54 to $-102 \%$ for $\delta^{2} \mathrm{H}$ (Fig. 10). The values are lowest where the Dundee Formation is overlain by black shale of the Marcellus Formation which forms a barrier to vertical infiltration of modern meteoric water, and highest at the Port Dover Quarry where stripping of unconsolidated sediments has exposed the Dundee Formation at the surface. The hydraulic gradient within the shallow bedrock in this area is down-dip, from north to south, with active flow as indicated by the artesian discharge. The results are interpreted to indicate the

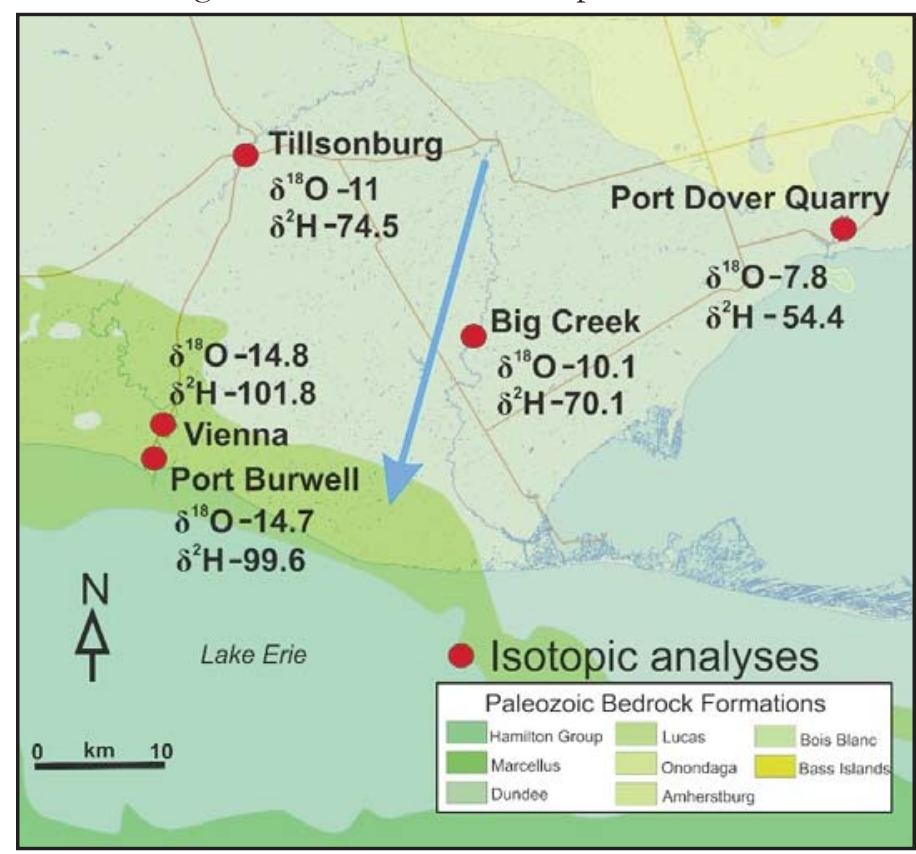

Figure 10. Isotopic results for sulphur water samples from the Lucas Formation and lower Dundee Formation, Norfolk and Elgin counties, southern Ontario, showing progressively lower $\delta^{18} \mathrm{O}$ and $\delta^{2} \mathrm{H}(\%$, VSMOW), with increasing depth, in a down-dip direction, interpreted to indicate a transition from modern meteoric water to water of likely glacial origin over a down-dip distance of 20 to $25 \mathrm{~km}$. Arrow shows regional dip of bedrock formations and regional groundwater flow direction. 
down-dip penetration of glacial meltwaters into the deeper portions of the lower Dundee Formation, with more recent infiltration of modern meteoric water at shallow depths.

These observations are consistent with studies by McIntosh and Walter (2006) and McIntosh et al. (2012) documenting extensive large-scale infiltration of Pleistocene glacial meltwaters into Silurian-Devonian carbonate aquifers around the margins of the Illinois and Michigan basins. Finite-element model simulations of groundwater flow beneath the LIS demonstrate the potential for deep penetration of dilute glacial meltwaters into the carbonate aquifers of the Michigan Basin and displacement of saline formation waters (McIntosh et al. 2011).

\section{HYDROSTRATIGRAPHIC UNITS (HSU)}

Following hydrostratigraphic protocols and nomenclature of Maxey (1964) and Seaber (1988) hydrostratigraphic units (HSU) are referenced by the names of their host lithostratigraphic units, are predominantly either aquifers or aquitards, and have unique lithology, sedimentary structures and facies, and hydrogeological properties. In this study, hydrostratigraphic assignment and classification is primarily based on hydrogeological properties of the rocks at intermediate to deep intervals in the subsurface in order to isolate the effects of modern karstic dissolution in the shallow regime. Except within paleokarst horizons, carbonate and evaporite rocks usually form aquitards and even aquicludes in the intermediate to deep subsurface, but at shallow depths these same rocks may form shallow karstic fresh water aquifers. These up-dip transitions from aquitard to aquifer make unequivocal assignment of hydrostratigraphic units problematic. Further, some of these transitions must be inferred or interpreted due to gaps in borehole coverage and data collection.

The definition of a HSU as an aquifer is not meant to imply an active flow system. In most cases they probably are not active but we note that it is not possible to identify unique recharge and discharge at the scale of the study. As discussed above, in the deep groundwater system the basinal brines are static, with no modern discharge or recharge. In the intermediate system there is local evidence of recharge, in particular by glacial meltwater, but only limited discharge to the surface. Flow systems in karstic bedrock can be identified in the shallow groundwater regime but they are generally local or subregional with dominant flow directions directed along strike rather than down-dip (e.g. Priebe et al. 2021).

Water interval records from petroleum wells are the primary source of data for assignment of lithostratigraphic units as either aquifers or aquitards. Maps showing the geographic distribution of the reported water intervals by water type for each formation have been prepared by Carter et al. (2015a). As discussed above, for all bedrock formations, fresh water is encountered in the subcrop belts. This water occurs within near-surface unconfined or partially confined aquifers, within either the contact aquifer or shallow karst aquifer system. Within confined bedrock aquifers in the intermediate to deep groundwater regimes, drillers have not reported the occurrence of fresh water.
A regional, generalized assignment of lithostratigraphic units as aquifers, aquitards, and aquicludes is presented as a hydrostratigraphic chart in Figure 11. The chart is synthesized from all the stratigraphic, hydrogeological, isotopic and hydrochemical data and geological observations discussed above. Fifteen regional hydrostratigraphic units are proposed in this study (Table 4).

For clarity, there is no inference that hydrostratigraphic units classified as aquifers are uniformly porous and permeable. As documented below, in some aquifers water flow may be concentrated along a few very thin intervals, such as solution-widened bedding plane partings, which may be only a few millimetres or centimetres in thickness. Hydrostratigraphic units comprised of interbedded rock types and exhibiting lateral facies changes may have considerable variation in permeability. A HSU classed as an aquitard may include formations with such low hydraulic conductivity that they can be considered as aquicludes (see HSU 13).

\section{HSU 1: Surficial Sediment Aquifer/Aquitard System}

Details on the surficial sediment groundwater system are beyond the scope of this study, but a brief summary is provided as over $90 \%$ of the area is covered by surficial sediment and it is a critical component of the Contact Aquifer. The surficial sediment system comprises all the unconsolidated glacial and modern sediments that overlie the Paleozoic bedrock and forms a complex system of aquifers and aquitards. Deposits can be up to $250 \mathrm{~m}$ thick (Gao et al. 2006; Gao 2011) and consist of a mixture of clastic sediments in a variety of low-relief glacial landforms with rapid changes in thickness and poor lateral continuity. This leads to complex local groundwater flow patterns that can vary significantly over lateral distances of 100s or 1000s of metres (Singer et al. 2003; Sharpe et al. 2014). Coarse-grained sediments (gravel, sand) generally form aquifers and very fine-grained sediments (mud, clay) form aquitards. Therefore, aquifers within the overburden generally have limited geographic extent and predictability compared to bedrock aquifer systems.

Unconsolidated sediments usually exhibit much greater porosity than bedrock formations with pore space of up to 40 to $50 \%$ in coarse gravel and sand deposits (Sharpe et al. 2014). Areas of thick sediments in glacial moraines and buried bedrock valleys have the largest groundwater storage capacity. Typical rates of flow exhibit a very large range, from $\sim 1000$ to $0.00001 \mathrm{~mm}$ per day (Sharpe et al. 2014). The irregular topography also slows runoff and contributes to percolation of rainfall into the subsurface. The water is generally fresh, with local quality constraints.

Precipitation readily penetrates these sediments except in thick deposits of clayey till and glaciolacustrine clay and silt. In these clay-rich areas vertical flow velocities are so low that much of the groundwater originated during the late Pleistocene (Desaulniers et al. 1981; Aravena et al. 1995).

\section{HSU 2: Contact Aquifer System}

The Contact Aquifer HSU occurs at the contact between bedrock and surficial sediments and consists of the first few 


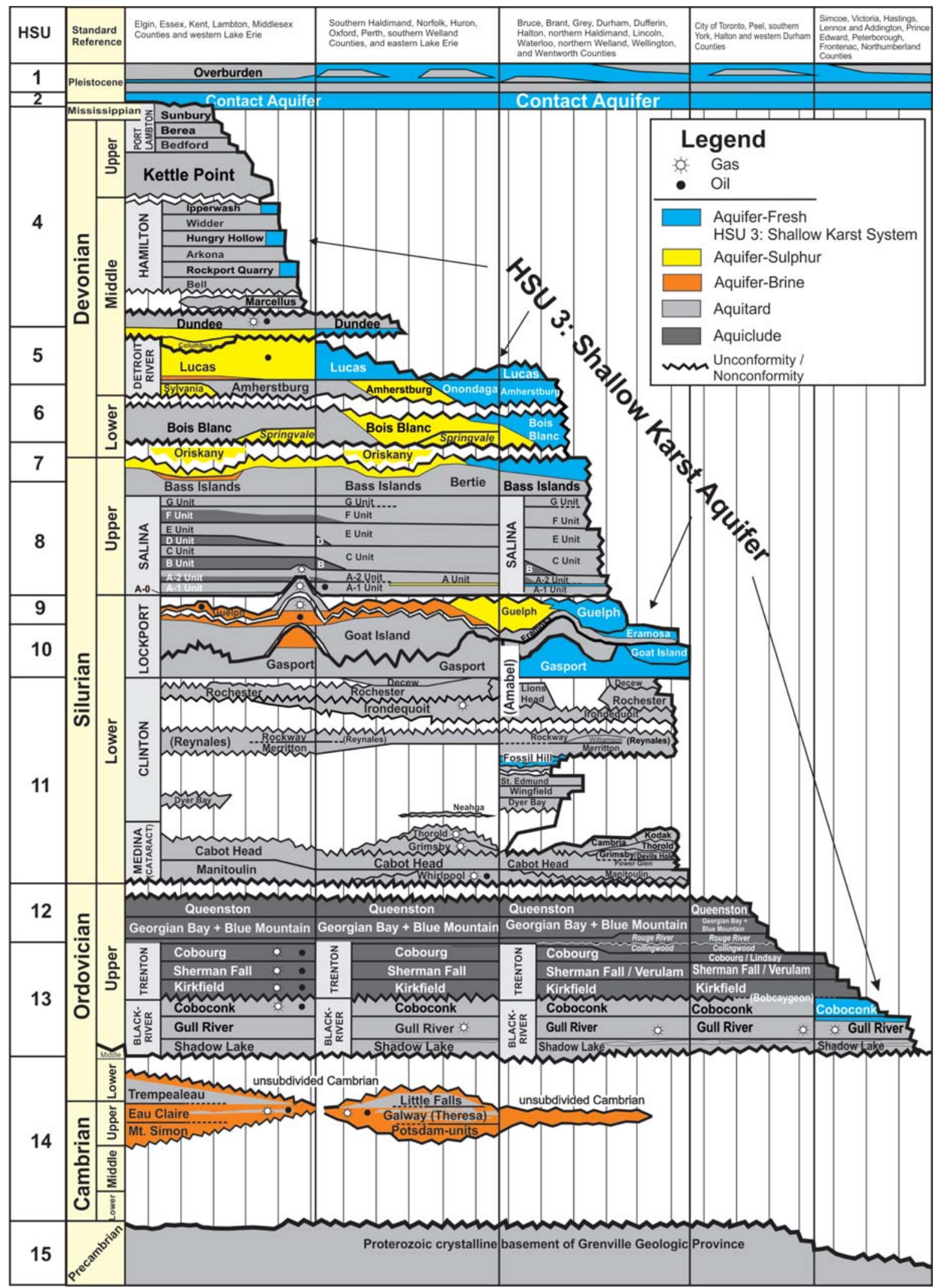

Figure 11. Hydrostratigraphic chart showing generalized assignment of bedrock lithostratigraphic units as regional aquifers, aquitards and aquicludes, and their HSU designations. The shallow karst aquifer system includes all fresh water aquifers in the subcropping carbonate bedrock, with the exception of the contact aquifer. Not included are isolated accumulations of brine in oil and gas reservoirs. The close relationship between regional disconformities and aquifers is directly related to the development of paleokarst at these intervals. 
metres of fully saturated jointed and fractured bedrock and the lowermost few metres of overlying sediment (Fig. 12). The water in the jointed bedrock and surficial sediment are in hydraulic communication and form one HSU with two quite different porosity systems: fracture porosity in the bedrock versus intergranular porosity in the sediment (e.g. Dillon Consulting Ltd. and Golder Associates Ltd. 2004; Husain et al. 2004; Strynatka et al. 2007; Carter and Fortner 2012). Records in WWIS indicate $40 \%$ of water wells in southern Ontario are drilled a few metres into the bedrock, terminating in either the contact aquifer or in the shallow karst aquifer system (Carter and Clark 2018). The contact aquifer is discordant to bedrock formation dips and underlies most of southwestern Ontario from Windsor to the Niagara Peninsula as far north as London and underlies most of the area east of the Niagara Escarpment to the edge of Paleozoic cover (Fig. 5).

The measured hydraulic conductivity of the Contact Aquifer HSU at a well in the Sarnia area was $1 \times 10^{-5} \mathrm{~m} / \mathrm{s}$ (Raven et al. 1990), but a considerable range of values is likely to be encountered. Regional water flow directions are controlled by the dip of the bedrock surface with local control by buried erosional cuestas and bedrock valleys. Topographic gradients drive recharge. The water within HSU 2 is generally potable, with local quality constraints, and mostly of modern meteoric origin, with several residual accumulations of glacial meltwater (Husein et al. 2004; Hamilton et al. 2015). Water compositions are dominated by $\mathrm{Ca}-\mathrm{HCO}_{3}$ and $\mathrm{Ca}-\mathrm{SO}_{4}$ with TDS averaging $770 \mathrm{mg} / \mathrm{L}$ (calculated from Hamilton 2015), and $\mathrm{pH}$ values ranging from 6.2 to 8.8. Groundwater chemistry is locally controlled by bedrock lithology (Singer et al. 2003).

\section{HSU 3: Shallow Karst Aquifer System}

A complex shallow system of fresh groundwater in carbonate, and less frequently evaporitic, bedrock has developed across large areas of southern Ontario due to karstic enhancement of porosity and permeability by meteoric water. This system is best developed at or near the subcrop surface of carbonate rocks in areas of thin overburden, along cuestas and near buried bedrock valleys. Stress-relief fracturing associated with these features further enhances the penetration of meteoric water (Cole et al. 2009; Priebe et al. 2019; Brunton and Brintnell 2020). Shallow karstic aquifers occur in the subcropping edges of most carbonate formations, including the Ipperwash, Hungry Hollow and Rockport Quarry formations in the Hamilton Group; the Dundee, Lucas, Amherstburg, Onondaga, Bois Blanc, Bass Islands, Fossil Hill, Gull River and Coboconk formations; and the Lockport Group. The most extensive shallow karst aquifers are developed in subcrops of the Lucas Formation and lower Dundee Formation and in the Lockport Group.

Shallow karstic aquifers in the Lockport Group subcrop belt are an important source of potable water in the area north of Brant County as described in detail by Brunton and Brintnell (2020) and Priebe et al. (2021). There is considerable geographic variation in aquifer development, with potable water found in the Guelph, Goat Island and Gasport formations, and locally the Eramosa Formation. Regional groundwater

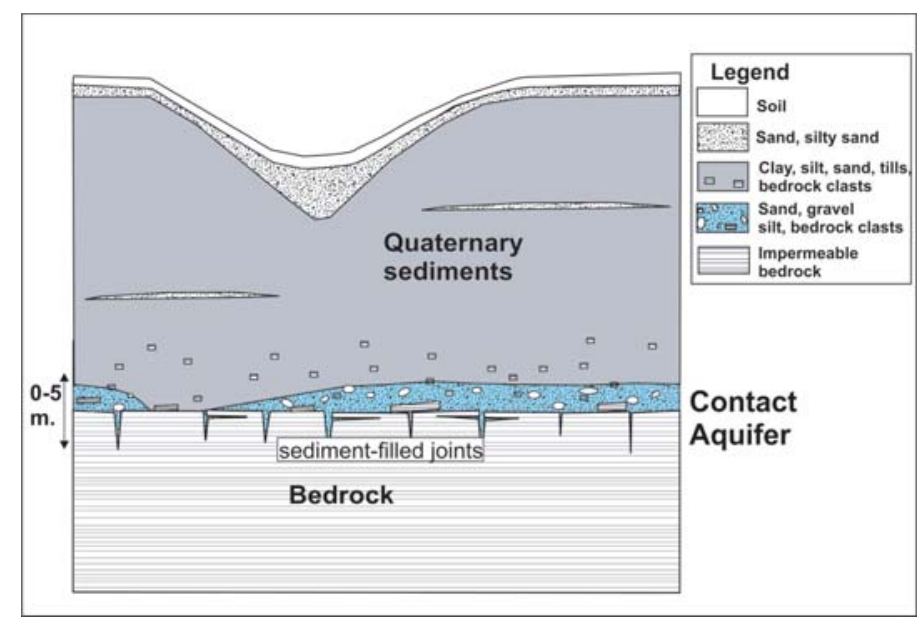

Figure 12. Conceptual model of the contact aquifer in the Chatham Sag, southwest of London, showing hydrogeological relationships relevant to areas where Kettle Point shale forms the top of bedrock.

flow is to the southwest and northwest, downgradient from the topographic high formed by the Niagara Escarpment and a local bedrock topographic high known as the Dundalk dome, and parallel to the regional strike of the Lockport Group carbonate units (Priebe and Brunton 2016; Priebe et al. 2021).

Within shallow inferred karst in carbonate bedrock the deepest fresh water intervals recorded in water well records are $130 \mathrm{~m}$ below the bedrock surface. It should be noted that water well drillers generally do not drill deeper than the first water interval capable of providing a reliable supply. Fresh water is locally reported in petroleum well records at depths of up to $250 \mathrm{~m}$ below the ground surface (Carter and Clark 2018).

\section{Lucas and lower Dundee Formations}

In HSU 3 the Lucas Formation is susceptible to karst development in subcrop and outcrop (Fig. 13), and also at shallow depths beneath the subcrop edge of the lower Dundee Formation, where solution-widened joints in the Dundee provide pathways for deep penetration of meteoric water. The presence of interbeds of soluble anhydrite and locally halite increases the susceptibility of the Lucas to karst development (Fig. 14). Evaporite dissolution is believed to have played a significant role in formation of the "breathing well zone", a local karstic aquifer in Huron County (Brunton and Dodge 2008; Freckelton 2012) (see Fig. 5).

Some of the largest and most extensive sinkhole fields in southern Ontario occur in areas of thin overburden in the subcrop belts of the Lucas and Dundee formations in Huron County and western Perth County (Brunton and Dodge 2008; Hurley et al. 2008). Meteoric water can be observed flowing into solution-widened joints in outcrop exposures of the Dundee Formation after heavy rainfall events. Immediately east of Goderich, in central Huron County, elliptical patches of dark water in aerial photographs mark the location of "black holes" in the bed of the Maitland River (Fig. 15). The black holes are sinkholes $10 \mathrm{~m}$ or more in depth in the bedrock which provide entry points for infiltration of water from the Maitland River into the Lucas Formation. Fresh water from 


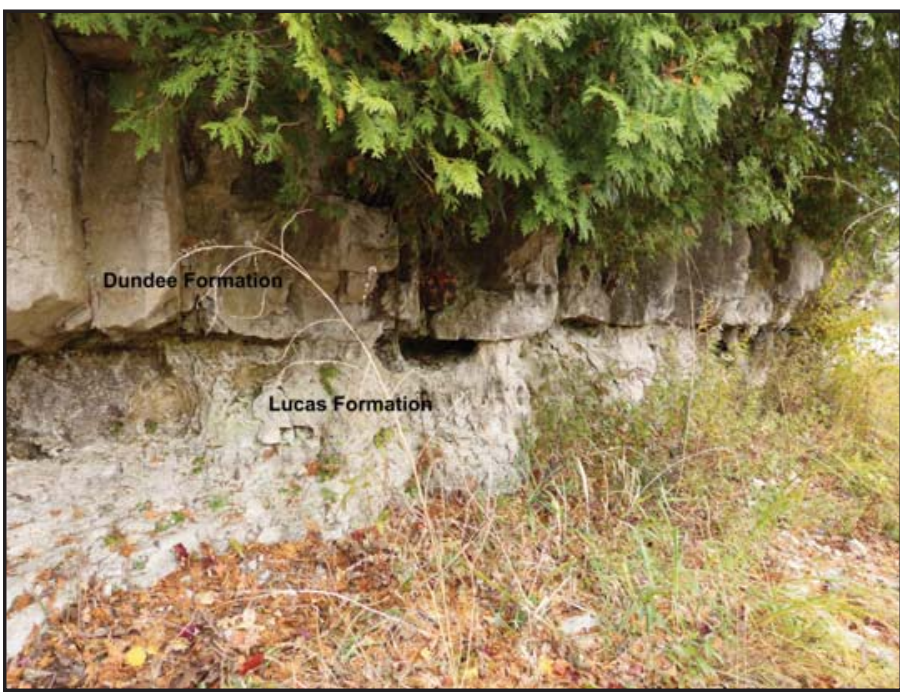

Figure 13. Large vugs in reactivated paleokarst zone in uppermost Lucas Formation, Colborne Riverside Park, Maitland River valley, Huron County. Cliff exposure is approximately 3 metres in height.

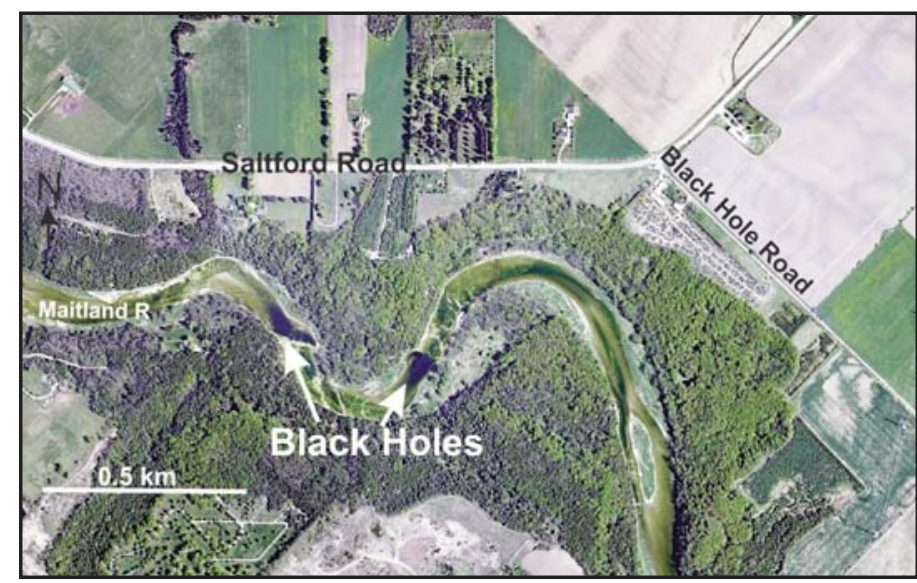

Figure 15. Aerial photograph of the Maitland River west of Goderich showing "black holes" in bed of Maitland River marking location of submerged sinkholes that are over $10 \mathrm{~m}$ deep in the Dundee and Lucas formations. The sinkholes provide entry points for infiltration of meteoric water into the bedrock.

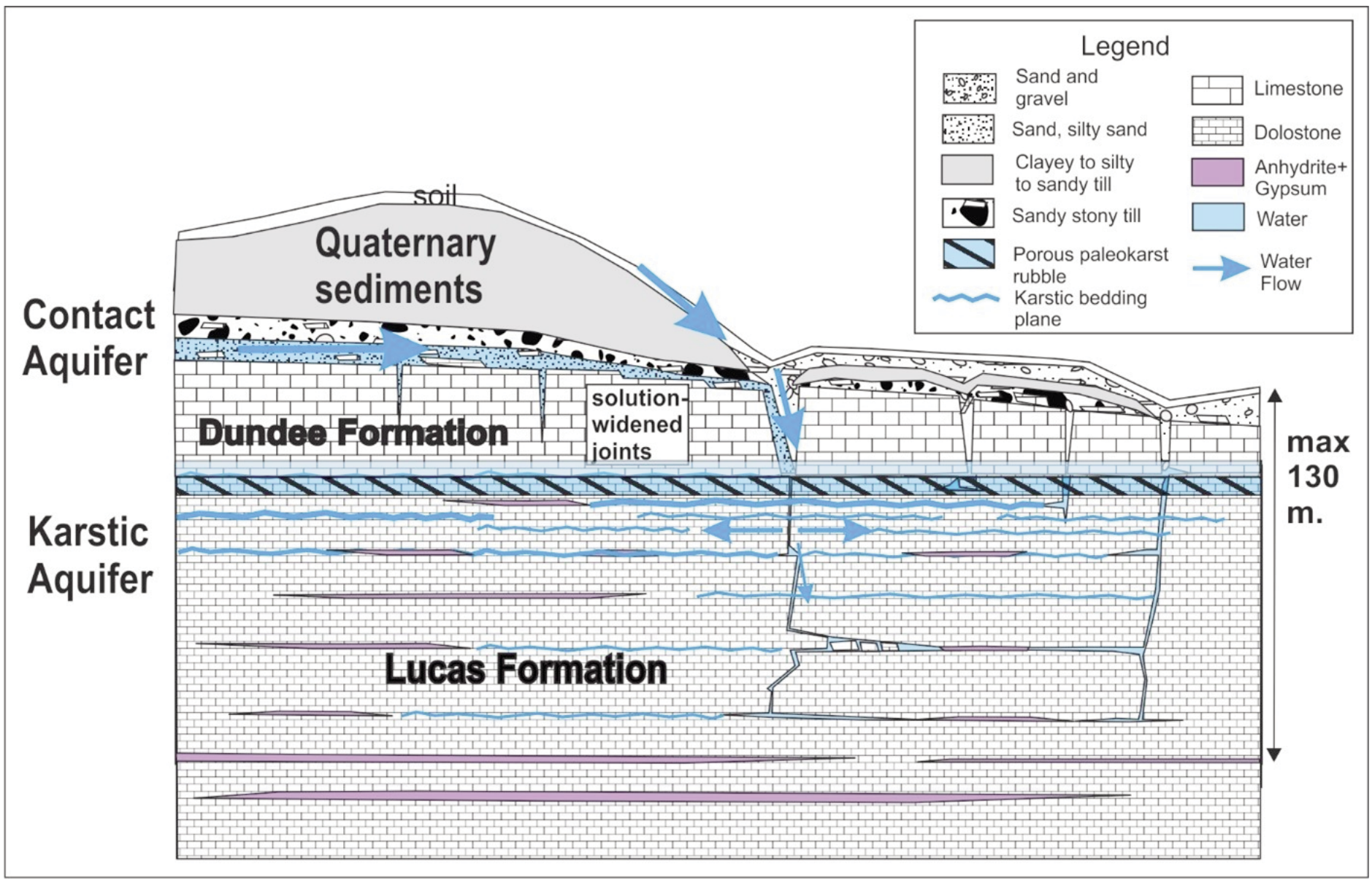

Figure 14. Conceptual model of shallow karst aquifer developed in subcropping limestone of the lower Dundee Formation and dolostone of the Lucas Formation, showing inferred flow directions. Based on field observations in outcrop and quarries (see Figures 15-18). 
the shallow karst aquifer recharges HSU 5, the confined Lucas-Dundee Aquifer, at intermediate depths down-dip from the subcrop belt. At the Bruce site, at a depth of $20 \mathrm{~m}$ below the surface, Intera Engineering Ltd. (2011) reported average hydraulic conductivity for the Lucas Formation in HSU 3 as $1 \times 10^{-6} \mathrm{~m} / \mathrm{s}$.

\section{Lockport Group}

The Lockport Group in HSU 3 is composed of carbonate rocks of the Gasport, Goat Island, Eramosa, and Guelph formations. These rocks are susceptible to karstification and development of fresh water aquifers where they are exposed at surface or in subcrop beneath shallow overburden, particularly in proximity to the Niagara Escarpment (e.g. Brunton 2013; Banks and Brunton 2017; Priebe et al. 2019; Brunton and Brintnell 2020). The City of Guelph relies primarily on groundwater from the Gasport Formation for its municipal water supply and to a lesser extent from the Guelph Formation. Flow zones occur at karst-enhanced stratigraphic breaks, bedding plane partings, and/or lithologic contrasts, which usually represent formation contacts (Priebe et al. 2017). North of Hamilton, Banks and Brunton (2017) have documented flow zones located at sequence and stratigraphic breaks in crinoidal grainstone and packstone of the Gasport and Goat Island formations, with others defined in the Eramosa and Guelph formations. The presently documented extent of the Gasport Aquifer is an area of approximately $10000 \mathrm{~km}^{2}$ northwest of the City of Hamilton (Priebe and Brunton 2016; Banks and Brunton 2017; Priebe et al. 2017, 2019).

From 23 different monitoring wells in the vicinity of the City of Guelph, Priebe et al. (2017) reported hydraulic conductivities for formations of the Lockport Group in HSU 3 ranging from $6 \times 10^{-7}$ to $5 \times 10^{-3} \mathrm{~m} / \mathrm{s}$, at depths of 17 to $100 \mathrm{~m}$ below the surface. The wide range of reported conductivities is directly related to depth below the present-day surface and the presence or absence of karst or solution-widened bedding plane partings. At shallow boreholes near the Niagara Gorge, Novakowski and Lapcevic (1988) measured hydraulic conductivity ranging from $5.5 \times 10^{-4}$ to $7.8 \times 10^{-11} \mathrm{~m} / \mathrm{s}$ in the Goat Island and Gasport formations, and a range from $2.8 \times 10^{-4}$ to $1.4 \times 10^{-8} \mathrm{~m} / \mathrm{s}$ for the Guelph Formation. Raven et al. (1992) reported a range from $2 \times 10^{-5}$ to $3.2 \times 10^{-9} \mathrm{~m} / \mathrm{s}$ for the Goat Island Formation. The higher $\mathrm{k}$ values in these shallow boreholes are indicative of the effects of post-glacial karstification.

Regional hydraulic gradient from the shallow karst aquifer into the subsurface is down-dip from the subcrop belt (Carter et al. 2015b) and is interpreted to be the likely pathway for penetration of glacial meltwater in the geologic past, and possibly modern meteoric water, into HSU 9 at intermediate depths. In the area of the subcrop belt north of Hamilton, recent mapping has established that flow is radially outward to the south, southwest and northwest from the Dundalk dome, a topographic high in the bedrock immediately west of the Niagara Escarpment (see Fig. 3), with flow directions parallel to the regional strike (Priebe and Brunton 2016; Priebe et al. 2021). Proximal to the Niagara Escarpment groundwater flow is to the east due to capture by solution-widened stress-relief joints and a network of shallow karst caves (e.g. Cowell and Ford 1983; Brunton and Dodge 2008).

\section{HSU 4: Devonian Aquitard}

HSU 4 consolidates in ascending stratigraphic order the upper portion of the Middle Devonian Dundee Formation, the Middle Devonian Marcellus Formation and Hamilton Group, the Upper Devonian Kettle Point Formation, and the Upper Devonian to Mississippian Port Lambton Group. These units form the uppermost bedrock beneath an onshore area of approximately $12000 \mathrm{~km}^{2}$ in southern Ontario (Fig. 1), with cumulative thickness of 130 to $180 \mathrm{~m}$. Starting from the upper Dundee Formation the HSU is composed of limestone that is disconformably overlain by organic-rich black shale of the Marcellus Formation, and then by calcareous shale and interbedded limestone of the Hamilton Group, in turn overlain disconformably by black, organic-rich shale of the Kettle Point Formation, and very locally by sandstone and shale of the Port Lambton Group.

Petroleum well drillers do not report significant amounts of water when drilling through this HSU (Carter et al. 2015a). Hydraulic conductivities are low, with reported values for the Kettle Point Formation of $3 \times 10^{-9}$ (Weaver 1994) and less than $1 \times 10^{-10} \mathrm{~m} / \mathrm{s}$ (Raven et al. 1990). Measured values for the Hamilton Group shale are $2.2 \times 10^{-11}$ (Weaver 1994) and $1 \times 10^{-12} \mathrm{~m} / \mathrm{s}$ (Raven et al. 1990). For the upper Dundee Formation Raven et al. (1990) reported measured hydraulic conductivity of $1 \times 10^{-11} \mathrm{~m} / \mathrm{s}$.

\section{HSU 5: Lucas-Dundee Aquifer}

HSU 5 consists predominantly of the Lucas Formation, the Columbus Formation and the lowermost few metres of the Dundee Formation, and is a major regional, confined aquifer in the intermediate subsurface. It underlies a land area of approximately $22000 \mathrm{~km}^{2}$ with a combined thickness of 40 to $110 \mathrm{~m}$. The aquifer is well known in the Ontario petroleum industry for the almost ubiquitous occurrence of sulphur water and the corrosive effect of this water on steel well casings. These same formations have produced over 45 million barrels of oil from oil reservoirs in Lambton County (Carter et al. 2016).

Water in the aquifer demonstrates a gradational increase in salinity down-dip from the shallow karst aquifer from brackish water to saline water containing elevated $\mathrm{SO}_{4}$ and dissolved $\mathrm{H}_{2} \mathrm{~S}$ at intermediate depths, to local occurrences of dense brine in the deepest part of the aquifer. In southern Ontario salinities vary from 1300 to $44000 \mathrm{mg} / \mathrm{L}$ TDS in the intermediate zone at depths from 50 to $180 \mathrm{~m}$ below the surface (Dollar et al. 1991; Weaver et al. 1995; Skuce et al. 2015b) with $\mathrm{Na}-\mathrm{Ca}-\mathrm{Cl}-\mathrm{SO}_{4}$ composition, and maximum $\mathrm{SO}_{4}$ content of $2000 \mathrm{mg} / \mathrm{L}$. In the state of Michigan, down-dip into the Michigan Basin, the aquifer reaches depths of 620 to $1560 \mathrm{~m}$, and Wilson and Long (1993) reported $\mathrm{Ca}-\mathrm{Na}-\mathrm{Cl}$ brines with TDS of 125000 to $387000 \mathrm{mg} / \mathrm{L}$.

Artesian flow of sulphur water is encountered by petroleum wells and deep water wells that intersect this aquifer in topographic lows such as Big Otter Creek and Big Creek in 


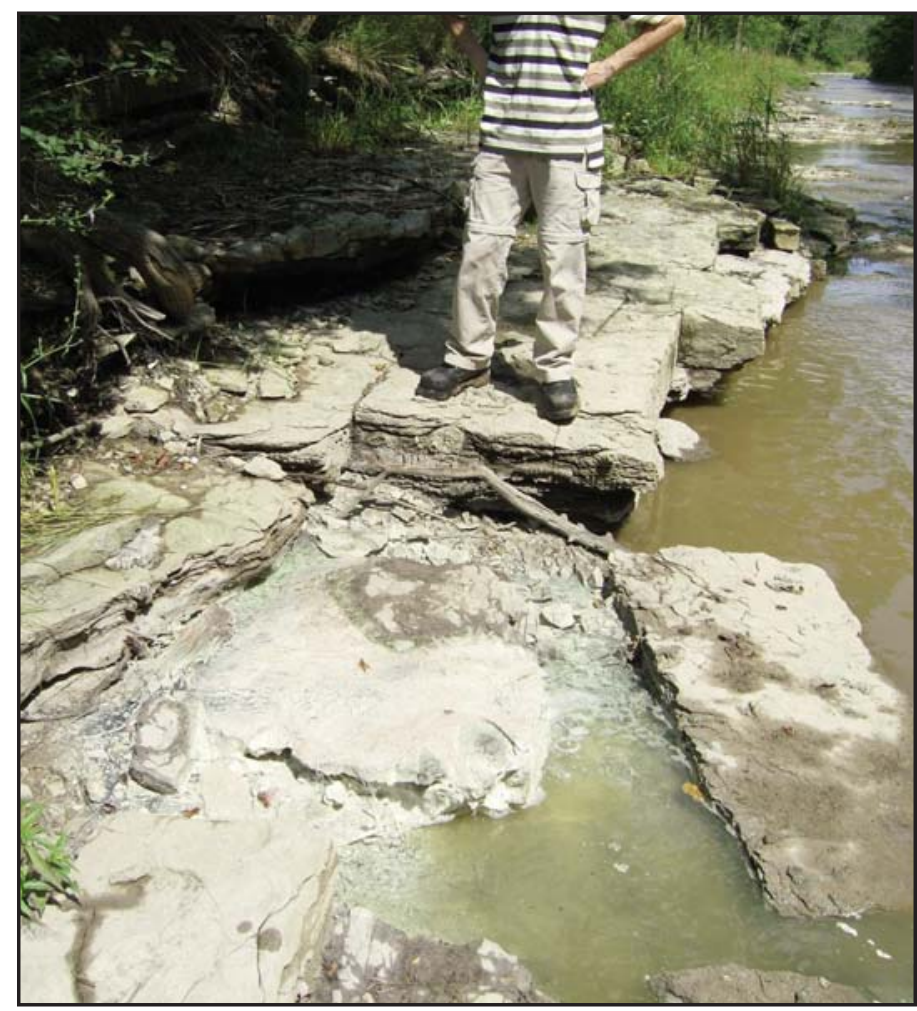

Figure 16. Sulphur water spring flowing into Hemlock Creek, $600 \mathrm{~m}$ north of Lake Erie. The spring flows out of a bedding plane parting in limestone at the contact of the Dundee Formation with the underlying Onondaga Formation.

Norfolk County and along the Lake Erie shoreline, where it constitutes a drilling hazard. Sulphur water also locally discharges into quarries and from natural springs (Figs. 16, 17, 18). As noted above microbial DNA analyses show abundant sulphur proteobacteria in artesian flow from the lower Dundee Formation in Norfolk County (Fig. 10).

On the Michigan Basin side of the Algonquin Arch, the Lucas Formation is the principal water-bearing unit in HSU 5. It is composed of fine-grained to very fine-grained restrictedmarine limestone and dolostone with anhydrite and gypsum beds in the lower half of the formation, and beds of quartzose sandstone in the upper portion. Occasional halite beds occur near Lake Huron and the St. Clair River. In Ontario, the Lucas Formation averages 25 to $40 \mathrm{~m}$ in thickness, reaching a maximum of $90 \mathrm{~m}$ in the Chatham Sag. It thins eastwards to its pinch-out edge in Norfolk County. Karstic dissolution of evaporite rocks and stromatolitic beds greatly enhances horizontal permeability. Petroleum wells have encountered severe loss-of-circulation and incompetent bedrock within the Lucas Formation during drilling in Lambton, Kent, and Huron counties. An unusual microporous dolomite is locally common (Hamilton 1991), which may also have a significant role in groundwater storage and movement. In the McGregor Quarry in Essex County, groundwater flow in the Lucas Formation is controlled by horizontal bedding plane partings a few millimetres wide (Fig. 17), which have been enhanced by karstic dissolution. Measured hydraulic conductivity in the Lucas Formation varies considerably from $1 \times 10^{-6}$ to $2 \times 10^{-9} \mathrm{~m} / \mathrm{s}$ (Raven et

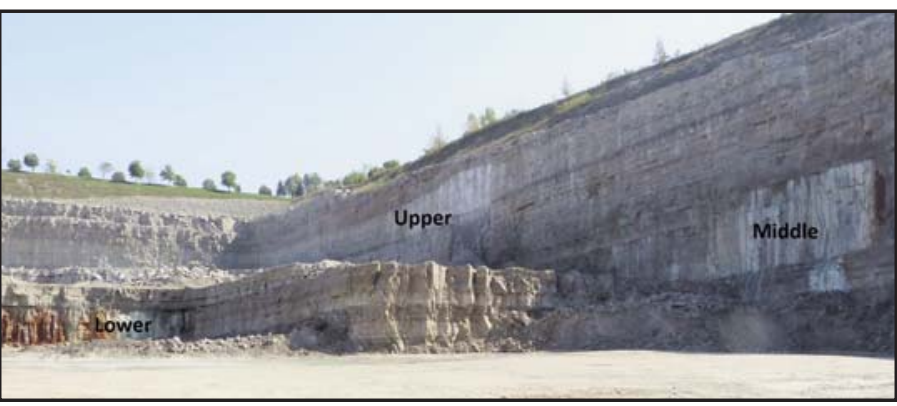

Figure 17. Inflow of sulphur water along bedding plane partings in the Lucas For mation on the southern face of the McGregor Quarry. Inactive zones are marked by white residue immediately below the bedding plane. The red staining on the lower bench marks an active inflow with a rotten egg smell, indicative of the presence of sulphur-oxidizing bacteria. Exposed bedrock thickness is approximately 40 m. Photograph taken October 18, 2013.

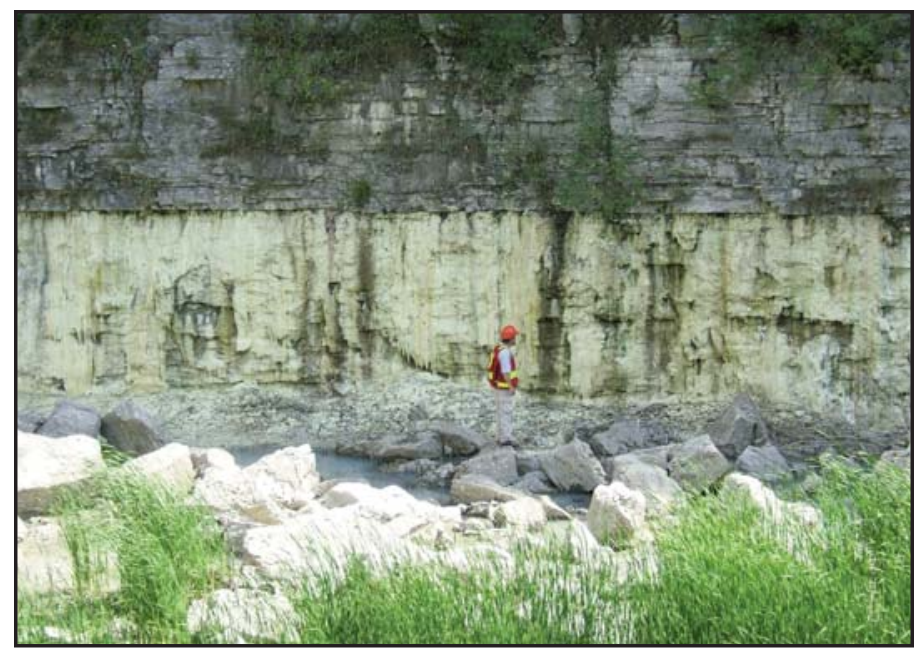

Figure 18. Water inflow along a horizontal bedding plane parting in limestone of the lower Dundee Formation, Port Dover Quarry. Yellow slime covering the quarry walls is a vigorous population of sulphur-oxidizing bacteria.

al. 1990; Intera Engineering Ltd. 2011) due to the varying sample depths, the differing degrees of karstic dissolution, and the presence or absence of horizontal fractures.

The Dundee Formation disconformably overlies the Lucas Formation and is composed of up to $45 \mathrm{~m}$ of fossiliferous limestone, of which only the lower few metres is considered, with the Lucas, as an aquifer. Petroleum wells consistently encounter water in the lower few metres of the formation, and in Lambton County the lower Dundee Formation is the principal oil-producing interval in Devonian oil reservoirs. East of the Algonquin Arch and the pinch-out edge of the Lucas Formation in central Norfolk County (see Fig. 1), the basal Dundee Formation becomes the principal aquifer. Water flow into the Port Dover Quarry in Norfolk County is confined along bedding plane partings in the Dundee Formation (Fig. 18). At a deep monitoring well drilled through the Dundee, Lucas and Amherstburg formations near Sarnia, Raven et al. (1990) reported measured hydraulic conductivity of $1 \times 10^{-8}$ to $1 \times 10^{-9} \mathrm{~m} / \mathrm{s}$ for the lowermost few metres of the Dundee, versus $1 \times 10^{-11} \mathrm{~m} / \mathrm{s}$ for the upper Dundee. Weaver (1994) reported hydraulic conductivity of $8.4 \times 10^{-8} \mathrm{~m} / \mathrm{s}$. 


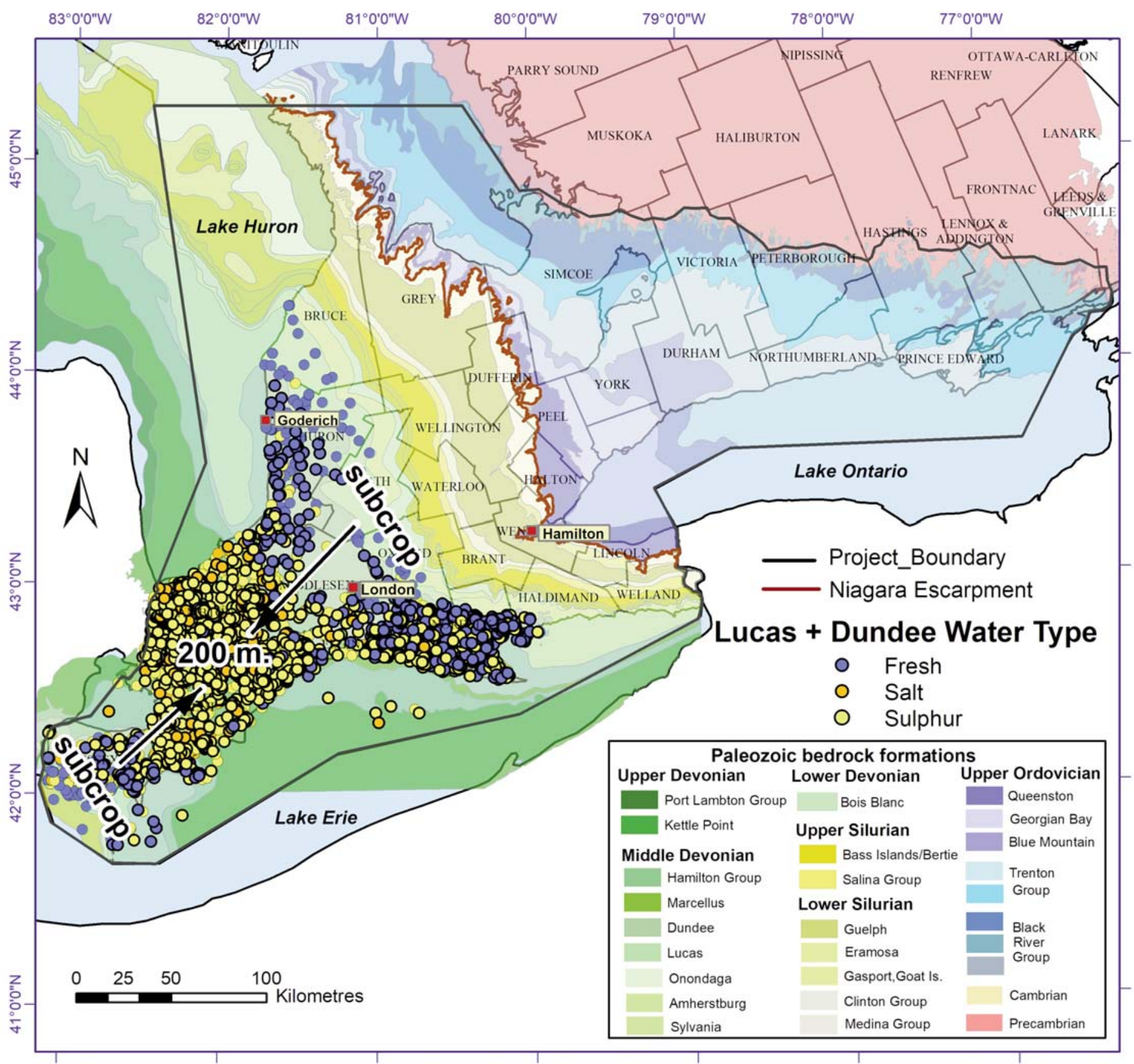

Figure 19. Map showing water-bearing intervals, by water type, encountered by petroleum wells while drilling through the Lucas Formation and Dundee Formation (from Carter et al. 2015a). There is a down-dip gradation from fresh water, to sulphur water, to saline water. Arrows show regional dips and depth to top of the Lucas Formation. Similar maps have been constructed for 35 formations and/or groups of formations, including all aquifers (adapted from Carter et al. 2015a).

\section{Recharge}

Recharge of the Lucas-Dundee Aquifer is from HSU 3, the Shallow Karst Aquifer, in subcrop exposures of the Lucas and lower Dundee formations. Hydraulic gradients are down-dip from HSU 3 towards the Chatham Sag and Lakes Huron and Erie, as indicated by hydrochemical zonation (Carter et al. 2015a) (Fig. 19), static level mapping (Carter et al. 2015b) (Fig. 20) and down-dip decreases in the water's $\delta^{18} \mathrm{O}$ and $\delta^{2} \mathrm{H}$ (Fig. 10). Water type mapping indicates a transition from fresh to sulphur water approximately 20 to $35 \mathrm{~km}$ down-dip from the subcrop belts of the Lucas and Dundee formations (Fig. 19) (Carter et al. 2015a). Isotopic data collected in Norfolk County for this study indicate a transition from modern meteoric water to water of likely glacial origin at similar distances (Fig. 10).

\section{HSU 6: Amherstburg-Bois Blanc Aquitard}

HSU 6 comprises the Bois Blanc, Amherstburg and Onondaga formations, including the Sylvania Formation and the Springvale Member of the Bois Blanc Formation and underlies a land area of $\sim 23000 \mathrm{~km}^{2}$. Thickness ranges from 40 to $90 \mathrm{~m}$, thick- 


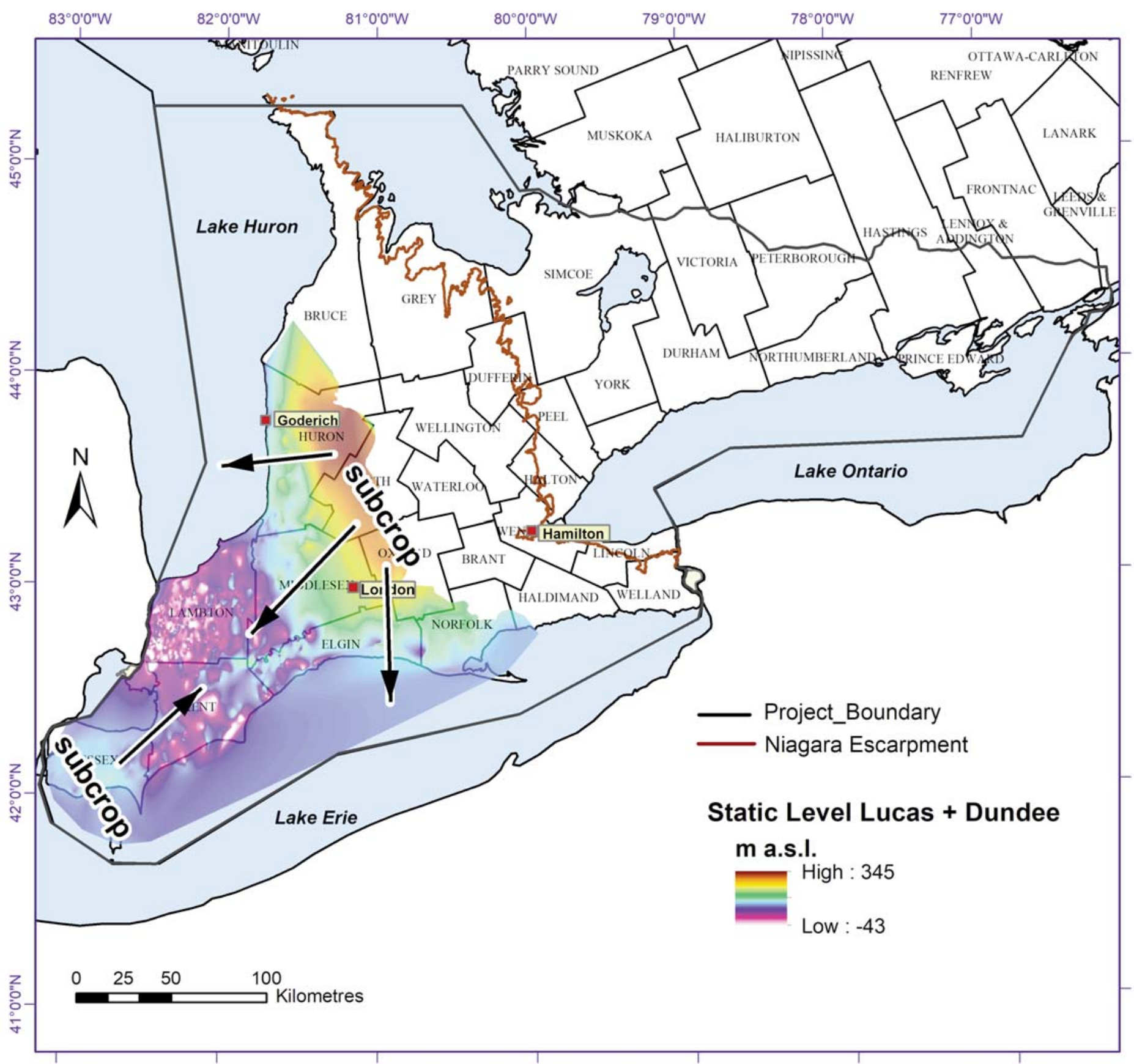

Figure 20. Static level map for fresh and sulphur water in the Lucas Formation and the lower Dundee Formation, showing down-dip hydraulic gradient from HSU 3 in the subcrop belt into HSU 5 (adapted from Carter et al. 2015b).

ening into the Chatham Sag and westwards into the Michigan Basin.

Conformably underlying the Lucas Formation, the Amherstburg Formation consists of 20 to $60 \mathrm{~m}$ of limestone and dolostone. In Norfolk County and farther east, the Amherstburg Formation, together with the Lucas Formation, is transitional into cherty limestone of the Onondaga Formation (Armstrong and Carter 2010; Sun 2018). Raven et al. (1992) measured hydraulic conductivity of $3.2 \times 10^{-11}$ to $7.9 \times 10^{-9} \mathrm{~m} / \mathrm{s}$ in the Amherstburg Formation at Sarnia. Sykes et al. (2011) reported hydraulic conductivity of $1 \times 10^{-6}$ to $1 \times 10^{-7} \mathrm{~m} / \mathrm{s}$ at both the Windsor and Goderich salt mines. These considerable variations are directly related to depth, with the higher conductivity values occurring at depths of less than $150 \mathrm{~m}$. Thick lenses of quartz sandstone of the Sylvania Formation underlie the Amherstburg Formation in the southwest corner of Essex County but no hydraulic conductivity data are available.

The Bois Blanc Formation consists of cherty fossiliferous limestone 3 to $50 \mathrm{~m}$ in thickness, locally with 3 to $10 \mathrm{~m}$ of glauconitic sandstone of the Springvale Member at the base. 
Measured hydraulic conductivity of $1 \times 10^{-8}$ to $1 \times 10^{-9} \mathrm{~m} / \mathrm{s}$ was reported at the Nanticoke tunnel (Intera Technologies Ltd. 1988).

\section{HSU 7: Bass Islands Aquifer}

HSU 7 comprises the upper half of the Silurian Bertie and Bass Islands formations, and the Devonian Oriskany Formation, in ascending order. It underlies a land area of approximately $24500 \mathrm{~km}^{2}$ with a thickness from $10-70 \mathrm{~m}$, thickening westwards into the Michigan Basin and the Chatham Sag, with local thickening over salt dissolution/subsidence features in the underlying Salina Group (Sanford 1969; Bailey Geological Services Ltd. and Cochrane 1985).

Dolostone beds of the Upper Silurian Bass Islands Formation have a continuous distribution in the subsurface of southern Ontario southwest of the subcrop edge. The underlying Bertie Formation dolostone only occurs beneath Welland County and eastern Haldimand County and easternmost Lake Erie. The upper contact of the Bass Islands Formation is a major unconformity and is the principal water-bearing horizon in HSU 7. Paleo-karstification of this surface has created solution-widened joints, many of which are locally filled with quartz sand of the Oriskany Formation, resulting in greatly enhanced porosity and permeability. The Oriskany Formation forms small outliers of calcareous quartz sandstone preserved within paleo-depressions on the surface of the Bass Islands Formation related to subsidence over salt dissolution features in the underlying Salina Group. At the Bruce site, the Bass Islands Formation has measured horizontal hydraulic conductivity varying from $1 \times 10^{-4}$ to $1 \times 10^{-5} \mathrm{~m} / \mathrm{s}$ for the upper $20 \mathrm{~m}$ and $1 \times 10^{-5}$ to $1 \times 10^{-6} \mathrm{~m} / \mathrm{s}$ for the lower $25 \mathrm{~m}$ (Intera Engineering Ltd. 2011). At the Goderich salt mine Intera Technologies Ltd. (1988), as cited by Sykes et al. (2011), reported values of $1 \times 10^{-6}$ to $1 \times 10^{-7} \mathrm{~m} / \mathrm{s}$. There are insufficient groundwater samples from HSU 7 at intermediate to deep depths to characterize its hydrochemistry.

\section{HSU 8: Salina Aquitard}

HSU 8 comprises the Salina Group and the lower half of the overlying Bass Islands Formation. It underlies a land area of approximately $31000 \mathrm{~km}^{2}$ with a maximum thickness of 420 $\mathrm{m}$ in the Chatham Sag thinning easterly to $120 \mathrm{~m}$. The Salina Group is dominated by evaporite rock types, including halite, anhydrite, gypsum and lime/dolomudstone. Thick beds of halite occur in the Salina A-2 Unit, B Unit, D Unit and F Unit west of the Algonquin Arch, and locally in the A-1 Unit in Huron County, exhibiting an eastward facies change to anhydrite and carbonate rocks, and an increase in shaliness east of the arch, and a corresponding decrease in thickness.

The zero edge of the salt beds, particularly in the B-Salt, is very abrupt, thinning from tens of metres to zero in as little as $1 \mathrm{~km}$ and is interpreted to be a dissolution front. When dissolution occurred after deposition and lithification of younger strata the overlying formations collapse into the dissolution voids and in drill core intersections the bedrock is observed to be fractured and brecciated (Armstrong and Carter 2010). This may have created pathways for subsequent downward or lateral movement of water, but this is conjectural. Underground observations of collapse breccia in salt mines in Ontario indicate no evidence of active groundwater infiltration.

At the Bruce site, the Salina Group formations have hydraulic conductivity varying from $3 \times 10^{-10} \mathrm{~m} / \mathrm{s}$ in the A-2 Unit to $5 \times 10^{-14} \mathrm{~m} / \mathrm{s}$ in the $\mathrm{F}$ Unit (Intera Engineering Ltd. 2011). Pore water composition varies from $\mathrm{Ca}-\mathrm{SO}_{4}$ with $30000 \mathrm{mg} / \mathrm{L}$ TDS in units of the upper Salina Group, to a dense $\mathrm{Na}-\mathrm{Cl}$ brine averaging $370000 \mathrm{mg} / \mathrm{L}$ in the Salina A-1 and A-2 units (Intera Engineering Ltd. 2011). At a depth of $510 \mathrm{~m}$ in the Goderich Salt mine, two samples of $\mathrm{Ca}-\mathrm{Na}-\mathrm{Cl}$ brine obtained from dewatering boreholes drilled into the A-2 Carbonate immediately above the A-2 Salt contained 375000 to $391000 \mathrm{mg} / \mathrm{L}$ TDS (Skuce et al. 2015b).

In the subsurface, the presence of intact salt beds is proof of lack of groundwater movement through these rocks subsequent to deposition, and in these areas the Salina Group can be considered as an aquiclude. At the Bruce site, an anomalous water-bearing paleokarst horizon occurs in the uppermost 3.5 $\mathrm{m}$ of the A-1 Carbonate (Intera Engineering Ltd. 2011) at a depth of $340 \mathrm{~m}$. Two water samples contained $26760 \mathrm{mg} / \mathrm{L}$ and $30455 \mathrm{mg} / \mathrm{L}$ TDS, typical of the intermediate groundwater regime, but inconsistent with the dense porewater brines in the enclosing formations of the Salina Group. The water also has an anomalous $\delta^{18} \mathrm{O}=-14.4 \% 0$ and $\delta^{2} \mathrm{H}$ of $-104 \%$, suggestive of glacial meltwater. Flow direction was determined to be to the northwest, down-dip towards the Michigan Basin. Petroleum well data indicates the continuity of this paleokarst horizon to the subcrop belt, as discussed above. Horizontal hydraulic conductivity for this zone, as measured at the Bruce facility, averaged $2 \times 10^{-7} \mathrm{~m} / \mathrm{s}$.

\section{HSU 9: Guelph Aquifer}

HSU 9 consists primarily of dolostone of the Guelph Formation, and locally the uppermost few metres of the underlying Goat Island Formation. It underlies a land area of approximately $38000 \mathrm{~km}^{2}$ and varies from $2 \mathrm{~m}$ to over $100 \mathrm{~m}$ in thickness.

The Lockport Group, of which the Guelph Formation is the uppermost formation, forms a gently dipping layer, thickening from west to east, and underlies all of southern Ontario west of the Niagara Escarpment. A distinctive series of lithofacies belts is preserved in the Guelph Formation as a result of a complex depositional, erosional, and diagenetic history, consisting of a carbonate platform in the east with carbonate banks/reefs, a regional paleokarst to the west, and an intervening pinnacle belt with inter-pinnacle karst (Fig. 21). There are considerable differences in hydrogeological characteristics of the Guelph Formation in the different lithofacies belts.

The regional paleokarst is a porous and permeable breccia or paleosol rubble (Fig. 22), 2 to $8 \mathrm{~m}$ thick, extending downward into the uppermost Goat Island Formation (Smith 1990; Carter et al. 1994; Brunton and Brintnell 2020). Within the eastern extent of the paleokarst is a $50-\mathrm{km}$ wide belt of pinnacles of thickened Gasport, Goat Island and Guelph carbonate rocks, separated by the same paleokarst breccia. The "pinnacles" have heights exceeding $100 \mathrm{~m}$ above the regional inter- 


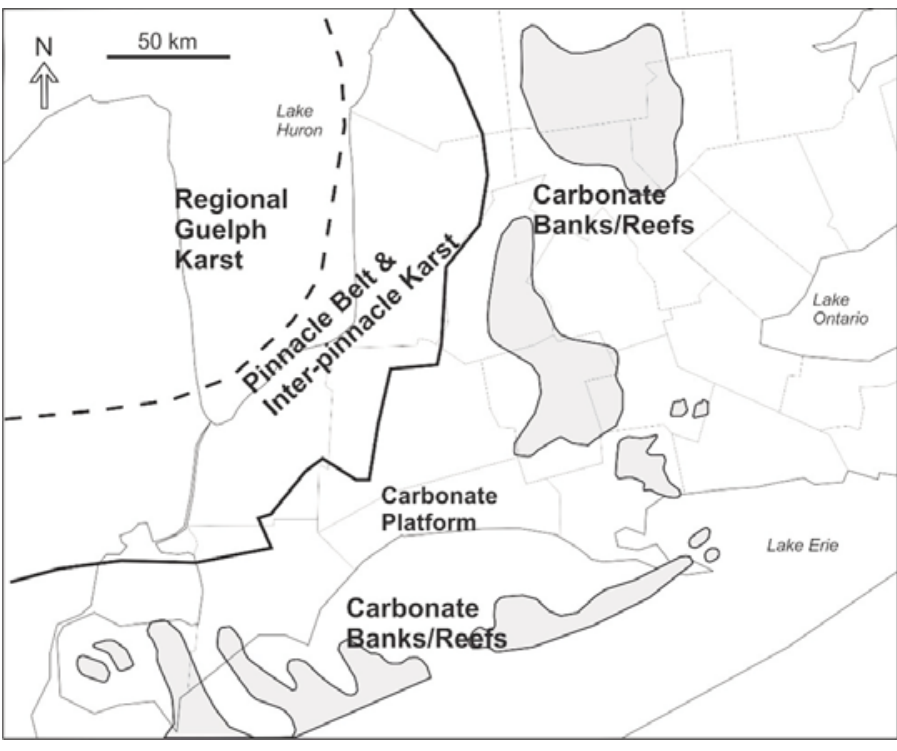

Figure 21. Lithofacies belts of the Guelph Formation in southern Ontario, showing carbonate banks or reefs on a southeast-dipping carbonate ramp and regional paleokarst and inter-pinnacle karst to the west. Revised from Sanford (1969) and Carter et al. (1994), using data from Bailey Geological Services Ltd. and Cochrane (1988), 3-D visualization (Carter et al. 2019) and paleoenvironmental interpretations of Brunton and Brintnell (2020).

pinnacle Guelph surface, and shorter build-ups known as incipient mounds are commonly less than $30 \mathrm{~m}$. The pinnacles are interpreted as "karst towers" by Brunton and Brintnell (2020) and Brunton et al. (2012), but most previous workers have considered them to be pinnacle reefs (e.g. Sanford 1969; Gill 1977; Sears and Lucia 1979; Grimes 1987; Smith et al. 1988; Smith 1990; Charbonneau 1990a, b; Carter et al. 1994, 1996; Coniglio et al. 2003).

Both the pinnacles and the incipient mounds exhibit varying degrees of karstification. The resulting enhancement of porosity and permeability, and the vertical and lateral seal provided by the Salina Group, has created prolific reservoirs of oil and natural gas and natural gas storage reservoirs. Average measured porosity in storage reservoirs is $7.7 \%$ with some thin intervals exceeding 30\% porosity with maximum horizontal permeability of 1000 to 10000 millidarcies (Carter et al. 1996). Where no hydrocarbons are present the pinnacles and incipient mounds are filled with brine or the pore space has been infilled by secondary halite. The regional karst and inter-pinnacle karst are occupied by dense brines.

East of the pinnacle belt individual carbonate banks or reefs have a maximum Guelph Formation thickness of $100 \mathrm{~m}$ (Sanford 1969; Brintnell 2012) with 20 to $50 \mathrm{~m}$ of relief on the Guelph Formation surface (Bailey Geological Services Ltd. and Cochrane 1988; Carter et al. 2019). Natural gas reservoirs occur in the banks or reefs beneath Lake Erie, and in the absence of hydrocarbons these structures are filled with brine.

In the deep brine regime salinities range from 153000 to $441000 \mathrm{mg} / \mathrm{L}$ TDS for pinnacles (Dollar et al. 1991; Skuce et al. 2015b) at depths of 354 to $770 \mathrm{~m}$, and 365000 to 375000 $\mathrm{mg} / \mathrm{L}$ for inter-pinnacle karst (Intera Engineering Ltd. 2011) at a depth of $390 \mathrm{~m}$. There is an up-dip transition from brine to

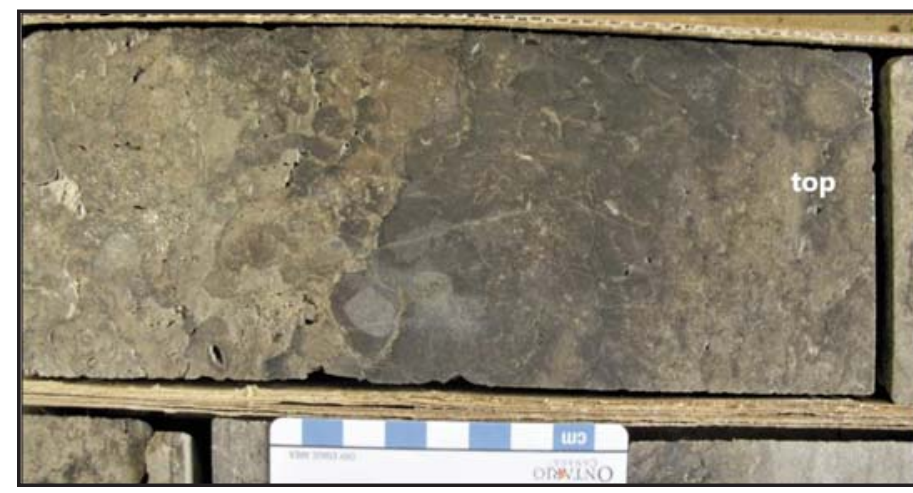

Figure 22. Dark brown to black, dolostone paleokarst rubble in the inter-pinnacle Guelph Formation, $800.5 \mathrm{~m}$ below rig floor. Drill core from petroleum well Tec. Dow 4, Moore 21-XII, in Lambton County, well licence \#T007290, core \# 996 at the OGSRL. This paleokarst rubble forms a regional brine aquifer in the regional karst and inter-pinnacle karst belts in southern Ontario.

saline to brackish groundwater at intermediate depths (Carter and Sutherland 2020), and to fresh water in shallow modern karst in the subcrop belt. Horizontal and vertical hydraulic conductivity of the inter-pinnacle Guelph is $3 \times 10^{-8} \mathrm{~m} / \mathrm{s}$ at the Bruce site (Intera Engineering Ltd. 2011). Raven et al. (1992) recorded measurements of $6.3 \times 10^{-5}$ to $7.9 \times 10^{-9} \mathrm{~m} / \mathrm{s}$ at Niagara Falls.

Hydraulic gradient in the shallow and intermediate regimes is down-dip from the subcrop belt, from northeast to southwest (Carter et al. 2015b). Groundwater in the deep brine regime exhibits hydraulic gradients up-dip from both the Appalachian Basin (Carter et al. 2015b) and from the Michigan Basin (Intera Engineering Ltd. 2011). The degree of connectivity and mixing between the intermediate and deep groundwater regimes in HSU 9 is unknown.

\section{HSU 10: Lower Lockport Aquitard}

HSU 10, the lower Lockport Aquitard, underlies $41000 \mathrm{~km}^{2}$, is 20 to $110 \mathrm{~m}$ thick, and comprises, in ascending order, dolostone of the Gasport, Goat Island and Eramosa formations of the lower Lockport Group. In the intermediate to deep subsurface of most of southern Ontario, where they are confined beneath the Salina Group, these formations are aquitards. Within the subcrop belt these same formations are porous and permeable and are included in HSU 3. In the deep subsurface at the Bruce site, far below the influence of surface water, at a depth of $378.6 \mathrm{~m}$, the Goat Island Formation has a measured hydraulic conductivity of $2 \times 10^{-12} \mathrm{~m} / \mathrm{s}$ (Intera Engineering Ltd. 2011).

\section{HSU 11: Clinton-Medina Aquitard}

HSU 11, the Clinton-Medina Aquitard, consists of the combined Clinton and Medina groups (Fig. 2) and underlies a land area of $42000 \mathrm{~km}^{2}$ with a thickness averaging 40 to $70 \mathrm{~m}$. Shale of the Cabot Head Formation of the Lower Medina Group forms a major confining bed throughout all of southern Ontario west of the Niagara Escarpment, with no fresh water found below this stratigraphic level (Brunton and Brintnell 2020). 
The upper part of this succession is dominated by limestone and dolostone: the DeCew, Irondequoit, Rockway (Reynales), Fossil Hill, and Merritton formations. The Rochester Formation forms a wedge of calcareous shale thinning to the northwest from a maximum of $24 \mathrm{~m}$ beneath eastern Lake Erie to its pinch-out along a line between Hamilton and Goderich. It transitions laterally to dolostone of the Lions Head Formation (Brunton and Brintnell 2020) on the Bruce Peninsula. The lower part of the succession is dominated by clastic sedimentary rocks east of the Algonquin Arch, including shale of the Neahga and Cabot Head formations, quartzose sandstone of the Thorold and Whirlpool formations, and interbedded shale, siltstone and quartzose sandstone of the Grimsby Formation. Sandstone contains natural gas throughout its distribution with sufficient permeability to support gas production where shale content is low (Carter et al. 2016). Small amounts of $\mathrm{Na}-\mathrm{Ca}-\mathrm{Cl}$ brine occur in association with natural gas production, with salinity ranging from 181000 to $407000 \mathrm{mg} / \mathrm{L}$ at depths of 226 to $572 \mathrm{~m}$ (Dollar et al. 1991; Skuce et al. 2015b). At the Bruce site the measured hydraulic conductivity of the formations comprising HSU 11 is low to very low, ranging from $5 \times 10^{-12} \mathrm{~m} / \mathrm{s}$ for the Lions Head and Fossil Hill formations to $9 \times 10^{-14} \mathrm{~m} / \mathrm{s}$ for the Cabot Head Formation (Intera Engineering Ltd. 2011).

\section{HSU 12: Ordovician Shale Aquiclude}

HSU 12, the Ordovician Shale Aquiclude, underlies a land area of $48000 \mathrm{~km}^{2}$, is up to $500 \mathrm{~m}$ thick, thinning northeast to under $175 \mathrm{~m}$ in Bruce County and erosional truncation in outcrop east of the Niagara Escarpment. It comprises the Upper Ordovician Queenston, Georgian Bay, and Blue Mountain formations. The three formations are comprised primarily of shale with subordinate siltstone and sandstone and limestone interbeds. The Queenston Formation is characterized by its distinctive red colour. For grey shale of the Georgian Bay and Blue Mountain formations the gradational contact, nonuniqueness of composition, and lack of distinct wireline log response make differentiation difficult.

At the Bruce site the Ordovician shale has a horizontal hydraulic conductivity of $2 \times 10^{-14}$ to $3 \times 10^{-14} \mathrm{~m} / \mathrm{s}$ and is significantly underpressured with uniform pore water composition of $\mathrm{Na}-\mathrm{Cl}$ brine averaging $300000 \mathrm{mg} / \mathrm{L}$ (Intera Engineering Ltd. 2011). These characteristics, in combination with the lack of water intervals reported from petroleum wells, indicate no significant fluid flow has occurred within HSU 12, supporting its designation as an aquiclude. Novakowski and Lapcevic (1988) reported values of $1 \times 10^{-8}$ to $1 \times 10^{-11}$ from deep boreholes at Niagara Falls.

\section{HSU 13: Trenton-Black River Aquitard}

HSU 13 is the Trenton-Black River Aquitard which underlies a land area of approximately $65000 \mathrm{~km}^{2}$ with a maximum thickness of nearly $250 \mathrm{~m}$ beneath west-central Lake Erie. It occurs at a depth of $850 \mathrm{~m}$ or more in the Windsor area, thinning to the northeast, and subcrops east of Toronto. It comprises all the formations of the Trenton and Black River groups.
The base of the aquitard is the predominantly argillaceous Shadow Lake Formation, which is generally 2 to $3 \mathrm{~m}$ thick, ranging to a maximum of $15 \mathrm{~m}$. It has an angular unconformable lower contact with either Cambrian sandstone and dolostone or Precambrian crystalline basement rocks. It is generally non-porous and non-permeable, with local exceptions, and forms a caprock to reservoirs of oil and natural gas in the underlying Cambrian formations. The Shadow Lake is conformably overlain by a cyclical sequence of lime mudstone, wackestone, packstone and bioclastic grainstone comprising the rest of the Trenton and Black River groups. North of London (see Fig. 5), the uppermost 1-10 m of HSU 13 consists of black, organic-rich shaly limestone and calcareous shale of the Collingwood Member of the Cobourg Formation. Where the Collingwood Member is absent the uppermost few metres of the Cobourg Formation is dolomitized (Armstrong and Carter 2010).

Hydraulic conductivity for the Shadow Lake Formation ranges from $1.0 \times 10^{-8}$ to $4.0 \times 10^{-14} \mathrm{~m} / \mathrm{s}$ (Raven et al. 1992; Golder Associates Ltd. 2003). At the Bruce site, limestone of the Trenton Group has an average porosity of $2.4 \%$ and an average horizontal hydraulic conductivity of $4 \times 10^{-15}$ to $1 \times 10^{-14}$ $\mathrm{m} / \mathrm{s}$. It is significantly underpressured with pore water composition of $\mathrm{Na}-\mathrm{Cl}$ brine varying from $285000 \mathrm{mg} / \mathrm{L}$ at the top to $230000 \mathrm{mg} / \mathrm{L}$ at the base (Intera Engineering Ltd. 2011). Black River Group limestone has an average porosity of $1.5 \%$, with an average horizontal hydraulic conductivity of $2 \times 10^{-11}$ to $1 \times 10^{-12} \mathrm{~m} / \mathrm{s}$. Golder Associates Ltd. (2003) obtained similar hydraulic conductivity values for the Trenton Group and Black River Group from deep boreholes along the northern shore of Lake Ontario. They are normally pressured to overpressured with pore water composition of $\mathrm{Na}-\mathrm{Cl}$ brine varying from $200000 \mathrm{mg} / \mathrm{L}$ to $230000 \mathrm{mg} / \mathrm{L}$ in the Gull River Formation (Intera Engineering Ltd. 2011). These characteristics, combined with the general lack of water documented in petroleum wells (Carter et al. 2015a), indicate that HSU 13 is an aquitard. The Trenton Group has been classified as an aquiclude by Intera Engineering Ltd. (2011) and $\mathrm{Al}$ et al. (2015) and is labelled as such on Fig. 11.

Local exceptions to the impermeable character of the Trenton and Black River groups occur where limestone has been dolomitized along vertical faults and fractures, principally in Kent and Essex counties (Middleton et al. 1993; Coniglio et al. 1994; Haeri-Ardakani 2013). This dolomite is porous and permeable with additional connectivity provided by fractures associated with the faults. These "hydrothermal dolomite" chimneys may be several kilometres in length, up to $1200 \mathrm{~m}$ in width and may extend vertically for over $100 \mathrm{~m}$ through the entire thickness of the Trenton and Black River groups (Davies and Smith 2006; Dorland et al. 2016). The structures are confined beneath shale of the Blue Mountain Formation. These dolomite reservoirs are prolific producers of oil and natural gas in Kent and Essex counties and the adjacent portions of Lake Erie in Ontario, and in southern Michigan. Dense $\mathrm{Na}-\mathrm{Ca}-\mathrm{Cl}$ brines occur in the basal portions of these reservoirs or, in the absence of hydrocarbons, occupy the full vertical extent of the hydrothermal dolomite zones. Salinities 


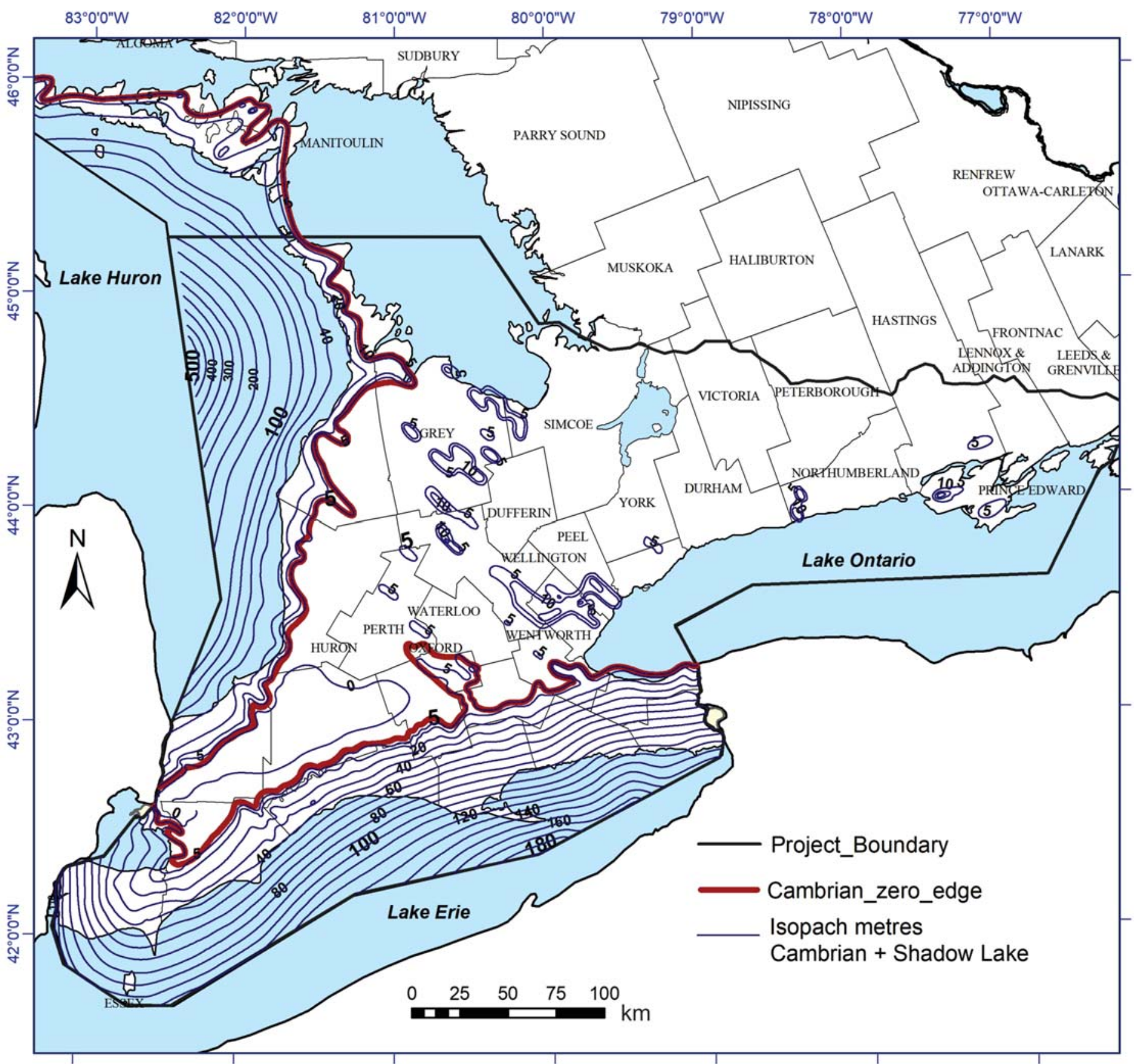

Figure 23. Isopach map of the combined Cambrian formations and Shadow Lake Formation and zero edge of the Cambrian strata, compiled from Sanford and Quillian (1959), Bailey Geological Services Ltd. and Cochrane (1984), Trevail (1990) and Ontario Geological Survey (2011). The Shadow Lake Formation underlies all southern Ontario except for a small area in Lambton and Middlesex counties. Cambrian units do not subcrop within the study area. Contour spacing is variable.

vary from 136000 to $403000 \mathrm{mg} / \mathrm{L}$ TDS (Dollar et al. 1991; Skuce et al. 2015b).

\section{HSU 14: Cambrian Aquifer}

HSU 14 is the Cambrian Aquifer which underlies a land area of $18500 \mathrm{~km}^{2}$ and most of Lake Huron and Lake Erie and is composed of all the Cambrian age formations in the subsurface of southern Ontario (Fig. 2). Cambrian strata are absent over the crest of the Algonquin Arch and thicken into the respective flanking basins to as much as $500 \mathrm{~m}$ beneath Lake Huron and $180 \mathrm{~m}$ beneath Lake Erie (Fig. 23).

Cambrian formations are dominated by sandstone in most of the onshore portion of southern Ontario. Beneath Lake Erie and Lake Huron it consists of quartzose sandstone and dolostone. The Cambrian strata experienced a prolonged period of exposure and erosion at the end of the Early Ordovician, as indicated by an extensive and intensive paleokarst horizon at the Knox Unconformity (Mussman and Read 1986; 


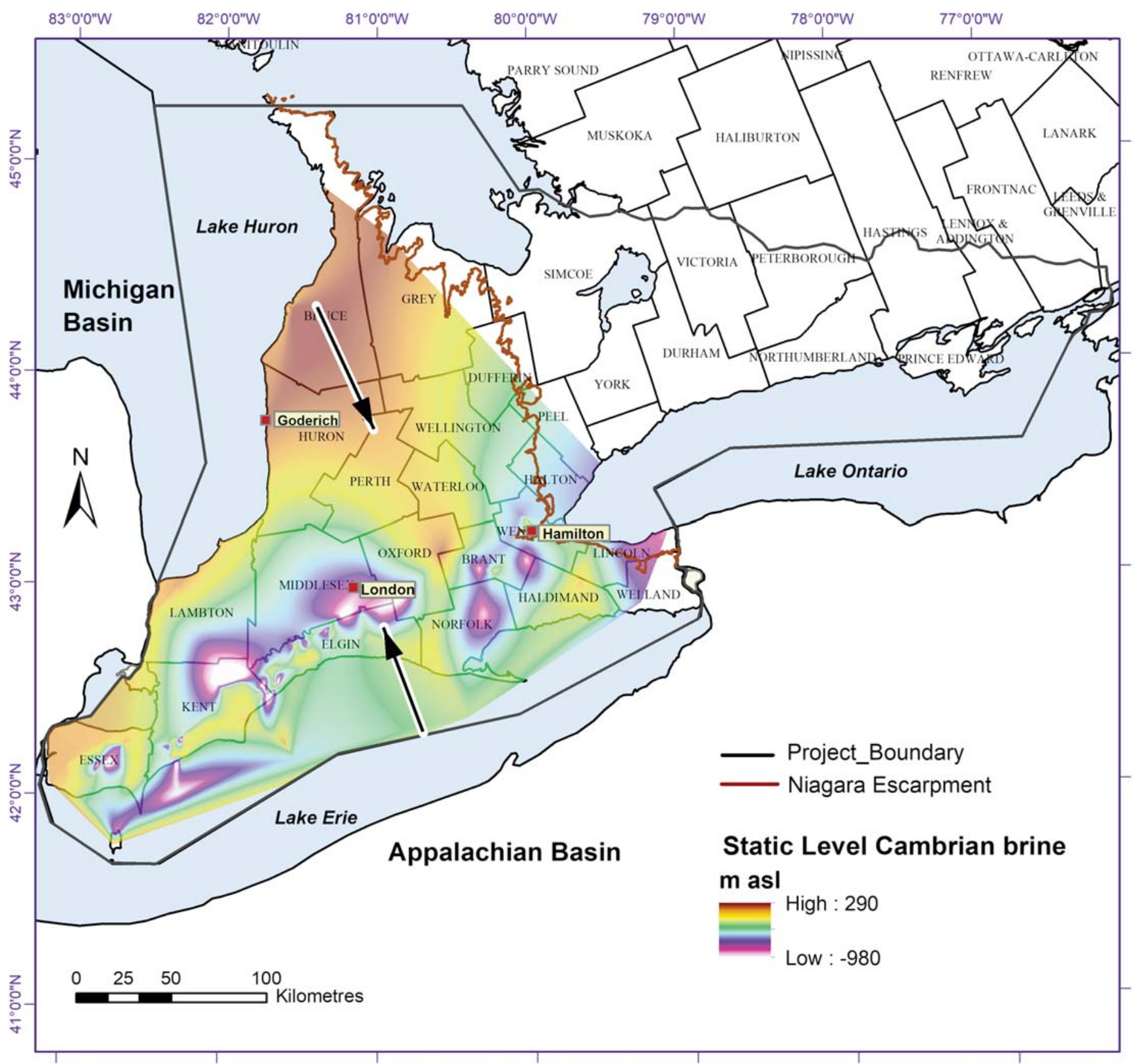

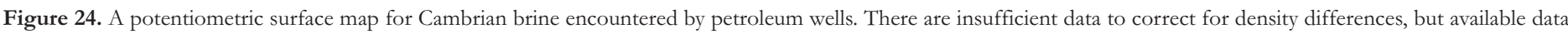

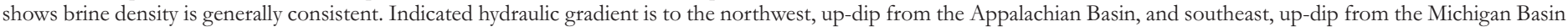
(Carter et al. 2015b).

Trevail 1990) and erosional removal over the crest of the Algonquin Arch (Johnson et al. 1992).

Groundwater in the Cambrian Aquifer is exclusively dense $\mathrm{Na}-\mathrm{Ca}-\mathrm{Cl}$ and $\mathrm{Ca}-\mathrm{Na}-\mathrm{Cl}$ brine ranging from 174000 to $423000 \mathrm{mg} / \mathrm{L}$ TDS (Dollar et al. 1991; Intera Engineering Ltd. 2011; Skuce et al. 2015b) in southern Ontario, similar to values obtained by Al-Aasm and Crowe (2018) for fluid inclusions in calcite and dolomite in deep drill core from the Bruce site. Measured hydraulic conductivity is $3 \times 10^{-6} \mathrm{~m} / \mathrm{s}$ (Intera
Engineering Ltd. 2011). Petroleum industry core analyses show average porosity of 9.2 to $11.8 \%$ to a maximum of $20 \%$ (Dorland et al. 2016). Hydraulic gradients are up-dip from both the Michigan Basin and the Appalachian Basin (see Fig. 24). At the Bruce site it is highly overpressured, with a formation pressure of $11000 \mathrm{kPa}$ and a calculated static level of 350 $\mathrm{m}$ asl (165 $\mathrm{m}$ above ground level; Intera Engineering Ltd. 2011). 


\section{HSU 15: Precambrian Aquitard}

Crystalline Precambrian metamorphic rocks of the Canadian Shield unconformably underlie the Paleozoic sedimentary rocks in southern Ontario. These rocks are gneiss of granitic, monzonitic, and tonalitic compositions (Armstrong and Carter 2010) all of which were affected by the Grenville Orogeny approximately 1 billion years ago (Easton 1992). This Grenville gneiss was subsequently peneplained by a prolonged period of erosion lasting upwards of 450 million years (R.M. Easton personal communication 2021).

Drillers do not report water-bearing zones in these rocks. The uppermost few metres of the Precambrian bedrock have been altered in southern Ontario and throughout the midcontinent of North America by warm basinal brines that migrated along the unconformity in response to Appalachian orogenic events (Lidiak and Ceci 1991; Harper et al. 1995; Ziegler and Longstaffe 2000a, b). Primary igneous minerals have been altered to illite, chlorite, albite, muscovite and calcite with pervasive occurrence of authigenic K-feldspar. Most of the wells that penetrate the Precambrian in southern Ontario reach total depth within the alteration zone and do not penetrate unaltered Precambrian bedrock (Armstrong and Carter 2010). Measured hydraulic conductivity of the alteration zone is $1 \times 10^{-10}$ to $1 \times 10^{-9}$ (Intera Engineering Ltd. 2011). A review of data from analogous unaltered Precambrian rocks elsewhere in the Canadian Shield by Intera Engineering Ltd. (2011) indicates hydraulic conductivity of $1 \times 10^{-12} \mathrm{~m} / \mathrm{s}$ and porosity of $0.5 \%$.

\section{DISCUSSION}

The purpose of this work is to provide a high-level hydrostratigraphic classification of the groundwater systems of southern Ontario as a foundation for 3-D modeling of the hydrostratigraphy. The focus is on groundwater systems in the intermediate to deep subsurface, which are usually ignored in groundwater studies as they do not contain potable water. The Paleozoic lithostratigraphy and the hydrogeological characteristics of the bedrock formations is the foundation for the hydrostratigraphic framework, and so it has been described in some detail. Understanding the geology is the key to understanding the hydrostratigraphy and being able to predict the occurrence of groundwater in the subsurface.

The proposed framework is amenable to further subdivision to accommodate local variability both geographically and stratigraphically (e.g. Intera Engineering Ltd. 2011). It is also subject to improvement, particularly at intermediate depths where the supporting data are relatively sparse. For the most part, the interpreted hydrostratigraphic units comply with the definition of Maxey (1964). The Shallow Karst Aquifer (HSU 3) and the Contact Aquifer are unconventional in that they cross formation boundaries rather than being confined within the lithostratigraphic framework. The defining characteristic of HSU 3 is confinement within shallow karstic carbonate rocks, and for HSU 2 it is the bedrock-surficial sediment interface. These two hybrid hydrostratigraphic units occur at the interface between the confined aquifers in the bedrock and the much more complex and fragmented aquifer systems in the overburden.
A considerable amount of hydrochemical and isotopic data is available from deep bedrock penetrations by oil and gas wells, mostly at depths greater than $250 \mathrm{~m}$. Conversely, most studies of fresh groundwater, and the drilling of water wells, are limited to shallow depths, generally less than $100 \mathrm{~m}$, due to the increase of salinity and other groundwater quality issues with depth. Data are sparse at depths from 100 to $250 \mathrm{~m}$, creating uncertainty about the interaction of shallow fresh groundwater with deeper saline and sulphurous groundwater. Water interval data from petroleum wells indicate a transition from fresh water to brackish to saline sulphur water occurs consistently at approximately 20 to $35 \mathrm{~km}$ down-dip from the subcrop edges of all bedrock aquifers, corresponding to a depth of approximately $100 \mathrm{~m}$. Down-dip decrease in $\delta^{18} \mathrm{O}$ and $\delta^{2} \mathrm{H}(\%$, VSMOW) over a similar distance, in Norfolk County, suggests that this transition indicates the presence of glacial meltwater in the intermediate groundwater regime. Further investigation is warranted.

Exposure of carbonate and evaporite strata to meteoric water at regional unconformities in the geologic past has resulted in development and enhancement of porosity and permeability at the unconformities. These "paleokarst" horizons are the principal geological control on groundwater occurrence in the bedrock of southern Ontario and host all the regional bedrock aquifers in the intermediate to deep subsurface. Recognition of these paleokarst horizons is key to understanding groundwater (paleo)flow in the bedrock. At shallow depths these paleokarst horizons may be reactivated and enhanced by modern (Quaternary) meteoric water. This knowledge has been used to guide exploration for new sources of groundwater (e.g. Banks and Brunton 2017).

Subsurface groundwater flow (paleo?) pathways in the intermediate to deep groundwater systems are stratabound along the regional unconformities and associated paleokarst. There is considerable evidence of dissolution of salt beds in the geologic past by cross-formational groundwater flow along faults (Sanford 1977; Armstrong and Carter 2010), but there is no evidence of present-day flow along faults. There have been no detailed studies of the timing of salt dissolution along faults, salt dissolution and collapse features related to faults, or direct impacts of faulting on modern groundwater flow. More fundamentally, there have been no comprehensive studies or interpretation of faulting in southern Ontario since the work of Brigham (1971a, b) with the exception of a recent lineament analysis (Béland-Otis 2020). An improved understanding of fault locations, geometry and potential for groundwater movement associated with faults is of particular significance for Ontario's two underground salt mines, at Windsor and Goderich.

Mapping of active groundwater flow systems in the shallow bedrock is beyond the scope and intent of this study and the reader is referred to recent work by the Ontario Geological Survey, e.g. Brunton and Brintnell (2020), Hamilton et al. (2015) and Priebe et al. (2021). The present study suggests that most groundwater movement in the shallow fresh groundwater system, HSU 1, 2 and 3, is subparallel to the gradient of the ground surface or the top of bedrock, with discharge back to 
the surface, including the beds of lakes Erie and Huron. Isotopic and hydrochemical data indicate that HSU 3, the shallow karst aquifer system, was a pathway for penetration of glacial meltwater into the intermediate groundwater system. No data are available on the volume or proportion of modern meteoric water that recharges from HSU 3 into the intermediate groundwater system. Depth of down-dip penetration is limited by density gradients created by the increasing salinity at depth and low regional topographic gradient, implying a major component of flow parallel to regional strike and discharge back to the surface. Down-dip decreases in the $\delta^{18} \mathrm{O}$ and $\delta^{2} \mathrm{H}$ of the groundwater, down-dip increase in salinity over relatively short distances, and the relatively few known sulphur water seeps and springs, suggest that modern recharge volumes to the intermediate groundwater regime are small, probably due to limited discharge pathways. This idea requires further investigation.

This study establishes a regional geological context for groundwater occurrence and pathways for groundwater flow in the bedrock. Flow systems with identifiable recharge and discharge can only be inferred in the intermediate regime with currently available data and do not presently exist in the deep regime.

Additional data on porosity and permeability of Paleozoic bedrock formations at intermediate to deep depths are available in core analysis data from 485 petroleum wells compiled by the OGSRL from MNRF regulatory submissions. Most of these cores were acquired within oil and natural gas reservoirs and, consequently, may not be regionally representative. Compilation and interpretation of core analysis data for the Lockport Group is the subject of current study by one of the authors (see Sun et al. 2020) with the goal of improving our understanding of the relationship between depositional and diagenetic facies and permeability within and between facies belts of the Lockport Group within the intermediate to deep subsurface, and possible connections to the shallow groundwater regime.

\section{CONCLUSIONS}

Thirty-five thousand (35 000) water interval records from the MNRF petroleum well database are the key source of information for hydrostratigraphic unit assignments in the subsurface Paleozoic bedrock of southern Ontario. Spatial analysis of these data has enabled the delineation of regional aquifers and aquitards in southern Ontario west of the Niagara Escarpment, identification of hydrochemical depth zonation of groundwater, and interpretation of regional groundwater hydraulic gradients in the intermediate to deep subsurface. Supporting information includes hydrochemical and stable isotope analyses of groundwater samples, field observations in outcrops and quarries, published hydraulic conductivity data from test wells and field studies, observations and interpretations of faults and fractures, microbial DNA analyses, and published geological, hydrochemical, karst and groundwater studies.

Hydrostratigraphic units occur within three groundwater hydrochemical regimes: a shallow fresh water regime, an inter- mediate brackish to saline sulphur water regime, and a deep brine regime. Flow directions in the shallow groundwater regime (HSU 1, 2) are down-gradient from topographic highs (Sharpe et al. 2014). Shallow karst (HSU 3) is the entry point for groundwater recharge down-dip into the intermediate regime, with paleo-recharge by glacial meltwater and limited recent recharge by meteoric water at subcrop edges. In the deep brine regime hydrostatic gradient is up-dip, at least for the Guelph Formation and Cambrian formations, but there is no evidence of groundwater movement except for induced flow near petroleum wells in response to extraction of oil and natural gas and associated brine.

Fifteen hydrostratigraphic units have been recognized, of which 7 are aquifers. The hydrostratigraphic units are named on the basis of the principal lithostratigraphic units within which they are contained. Most potable groundwater in southern Ontario is found in the Surficial Sediment Aquifer/ Aquitard System (HSU 1), the Contact Aquifer (HSU 2), and the Shallow Karst Aquifer System (HSU 3) within the shallow fresh water regime, which extends to depths of 100 to $250 \mathrm{~m}$ below the surface. Notably HSU 3 includes the up-dip edges of formations that at depth may be aquitards but in subcrop have enhanced porosity and permeability due to karstification by exposure to acidic meteoric water. This complicates unequivocal assignment of lithostratigraphic units to hydrostratigraphic units and extrapolation of aquitards and aquifers from the deep subsurface to subcrop. Identification of groundwater flow systems within the shallow fresh water regime is beyond the scope and intent of this study.

Hydrostratigraphic units within the intermediate and deep regimes include: Devonian Aquitard, Lucas-Dundee Aquifer, Amherstburg-Bois Blanc Aquitard, Bass Islands Aquifer, Salina Aquitard, Guelph Aquifer, Lower Lockport Aquitard, Clinton-Medina Aquitard, Ordovician Shale Aquiclude, Trenton-Black River Aquitard, Cambrian Aquifer, and the Precambrian Aquitard (Table 4, Fig. 11). Intermediate and deep regime aquifers are confined within thin, regionally extensive paleokarst horizons, separated by thick aquitards. The intermediate hydrochemical regime can extend from a few metres below the bedrock surface in shale units to depths of $350 \mathrm{~m}$, and locally $450 \mathrm{~m}$, and is closely correlated with recharge pathways for down-dip penetration of surface water and potential mixing with older formation fluids, particularly under subglacial hydraulic pressure. The deep hydrochemical regime is dominated by relatively immobile basinal brines that are calculated to be greater than $260 \mathrm{Ma}$ in some low permeability shale units (Clark et al. 2013). Where sufficient data are available, hydrostatic gradient is indicated to be up-dip in deep brine aquifers, but there is no evidence of groundwater movement except in response to extraction of oil, natural gas and associated brine.

Hydrostratigraphic units designated as aquifers are not uniformly porous and permeable. At intermediate depths principal flow zones are confined to karst-enhanced bedding plane partings only a few millimetres to centimetres in thickness.

The hydrostratigraphic units proposed here provide a regional framework subject to continual modification and 
improvement as new information becomes available. Additional complexity and detail at a local scale can and should be incorporated.

\section{ACKNOWLEDGEMENTS}

This study is a contribution to a collaborative 3-year project begun in 2019 by the GSC, OGS, and the OGSRL, to produce a 3-D hydrostratigraphic model for southern Ontario. Funding is provided by NWMO and GSC. The study builds on earlier work funded by the MNRF.

The ideas and concepts presented here have benefitted from discussions and collaborations with numerous geologists and hydrogeologists, including Derek Armstrong, Theo Beukeboom, Frank Brunton, Jeff Markle, Dick Jackson, Dave Sharpe, and Chris Smart. We acknowledge the important contribution to our understanding of the intermediate to deep groundwater regimes made by the world-class hydrogeological, hydrochemical and isotopic studies completed at the site of the Bruce Power nuclear generating facility on Lake Huron by the NWMO and their team of researchers, under the leadership of Mark Jensen. The assistance of Frank Brunton in development of early versions of the hydrostratigraphic chart is gratefully acknowledged.

Since 1998, the Oil, Gas and Salt Resources Library has executed a critical role in maintaining and enhancing Ontario petroleum well data using funding provided by the petroleum and salt industries of Ontario. This work has included very large undertakings of quality control and quality assurance of the data stored by MNRF in OPDS. This study could not have been completed without these data.

Landowners, petroleum well operators, and quarry owners provided access to their land and operations. Arthur Castillo of the MNRF provided training and mentoring to the first author in the use of ArcGIS to view and analyze data and create maps. Dr. Leigh Smith mentored the first author in the recognition of karst and paleokarst and its widespread occurrence in the Guelph Formation in the deep subsurface of southern Ontario. We thank Dr. Monique Hobbs of NWMO for her comprehensive and helpful review of this manuscript. We thank Ihsan Al-Aasm and an anonymous reviewer who provided constructive comments and critiques that have significantly improved the quality of the paper. We also thank the journal editors Andrew Kerr and Cindy Murphy for their supportive comments and sugges tions and Rob Raeside for thorough copy editing to prepare the paper for publication.

This is NRCan contribution number / Numéro de contribution de RNCan: 20200731, and Western's Laboratory for Stable Isotope Science Contribution \#384

\section{REFERENCES}

AECOM Canada Ltd., and Itasca Consulting Canada Inc., 2011, Regional geology southern Ontario: Nuclear Waste Management Organization, Report DGR-TR-2011-15, 154 p. Accessed June 11, 2013 at: http://www.nwmo.ca/uploads/DGR\%20PDF/Geo/Regional-GeologySouthern-Ontario.pdf.

Al, T.A., Clark, I.D., Kennell, L., Jensen, M., and Raven, K.G., 2015, Geochemical evolution and residence time of porewater in low-permeability rocks of the Michigan Basin, southwest Ontario: Chemical Geology, v. 404, p. 1-17, https://doi.org/10.1016/j.chemgeo.2015.03.005

Al-Aasm, I.S., and Crowe, R., 2018, Fluid compartmentalization and dolomitization in the Cambrian and Ordovician successions of the Huron Domain, Michigan Basin: Marine and Petroleum Geology, v. 92, p. 160-178, https://doi.org/10.1016/j.marpetgeo.2018.02.011.

Aravena, R., Wassenaar, L.I., and Barker, J.F., 1995, Distribution and isotopic characterization of methane in a confined aquifer in southern Ontario, Canada: Journal of Hydrology, v. 173, p. 51-70, https://doi.org/10.1016/00221694(95)02721-Z

Armstrong, D.K., and Carter, T.R., 2010, The subsurface Paleozoic stratigraphy of southern Ontario: Ontario Geological Survey, Special Volume 7, 301 p.

Bailey Geological Services Ltd., and Cochrane, R.O., 1984, Evaluation of the conventional and potential oil and gas reserves of the Cambrian of Ontario: Ontario Geological Survey, Open File Report 5499, 72 p.

Bailey Geological Services Ltd., and Cochrane, R.O., 1985, Evaluation of the conventional and potential oil and gas reserves of the Devonian of Ontario (Volume 1): Ontario Geological Survey, Open File Report 5555, 178 p.

Bailey Geological Services Ltd., and Cochrane, R.O., 1988, Isopach top Guelph to top Rochester, southern Ontario: Ontario Geological Survey, Preliminary maps 2992 to 3019.

Banks, W.D., and Brunton, F.B., 2017, Collaboration between Ontario Geological Survey, consultants and municipal staff results in discovery and development of a safe and sustainable bedrock groundwater supply for the Town of Shelburne, southern Ontario, Canada [Conference Paper]: GeoOttawa 2017, 6 p.

Barnett, P.J., 1992, Quaternary geology of Ontario, in Thurston, P.C., Williams, H.R., Sutcliffe, R.H., and Stott, G.M., eds., Geology of Ontario: Ontario Geological Survey, Special Volume 4, Part 2, p. 1011-1090.

Beauheim, R.L., Roberts, R.M., and Avis, J.D., 2014, Hydraulic testing of low-permeability Silurian and Ordovician strata, Michigan Basin, southwestern Ontario: Journal of Hydrology, v. 509, p. 163-178, https://doi.org/10.1016/j.jhydrol.2013.11.033.

Béland-Otis, C., 2020, Application of subsurface mapping to the interpretation of Paleozoic structures from lineament analysis of high-resolution aeromagnetic data in the Chatham Sag, southwestern Ontario: Ontario Geological Survey, Open File Report 6362, 171 p.

Bense, V.F., and Person, M.A., 2008, Transient hydrodynamics within intercratonic sedimentary basins during glacial cycles: Journal of Geophysical Research, v. 113, F04005, https://doi.org/10.1029/2007JF000969.

Brigham, R.J., 1971a, Structural geology of southwestern Ontario and southeastern Michigan: Unpublished PhD thesis, University of Western Ontario, ON, 214 p.

Brigham, R.J., 1971b, Structural geology of southwestern Ontario and southeastern Michigan: Ontario Department of Mines and Northern Affairs, Petroleum Resources Section, Paper 71-2,110 p.

Brintnell, C., 2012, Architecture and stratigraphy of the Lower Silurian Guelph Formation, Lockport Group, southern Ontario and Michigan: Unpublished MSc thesis, University of Western Ontario, ON, 242 p. Electronic thesis and dissertation repository, 632, https://ir.lib.uwo.ca/etd/632.

Brunton, F.R., 2013, Karst and hazards lands mitigation - Some guidelines for geological and geotechnical investigations in Ontario karst terrains; in Summary of Field Work and Other Activities, 2012: Ontario Geological Survey, Open File Report 6290, p.37-1 to 37-24.

Brunton, F.R., and Brintnell, C., 2020, Early Silurian sequence stratigraphy and geological controls on karstic bedrock groundwater-flow zones, Niagara Escarpment region and the subsurface of southwestern Ontario: Ontario Geological Survey, Groundwater Resources Study 13, $120 \mathrm{p}$

Brunton, F.R., and Dodge, J.E.P., 2008, Karst of southern Ontario and Manitoulin Island: Ontario Geological Survey, Groundwater Resources Study 5, 99 p.

Brunton, F., Brintnell, C., Jin, J., and Bancroft, A., 2012, Stratigraphic architecture of the Lockport Group in Ontario and Michigan - A new interpretation of early Silurian basin geometries and Guelph pinnacle reefs: Ontario Petroleum Institute, Proceedings, 51 $1^{\text {st }}$ Annual Conference, $37 \mathrm{p}$.

Brunton, F.R., Carter, T.R., Logan, C., Clark, J., Yeung, K., Fortner, L., Freckelton, C., Sutherland, L., and Russell, H.A.J., 2017, Lithostratigraphic compilation of Phanerozoic bedrock units and 3D geological model of southern Ontario (Abstract), in Russell, H.A.J., Ford, D., and Priebe, E.H., eds., Regional-scale Groundwater Geoscience in Southern Ontario: an Ontario Geological Survey, Geological Survey of Canada, and Conservation Ontario Open House: Geological Survey of Canada, Open File 8212, p. 3, https://doi.org/10.4095/299750.

Canadian Council of Ministers of the Environment, 2010, Review and assessment of Canadian groundwater resources, management, current research mechanisms and priorities, PN 1441, 12 p. Accessed July 2020: https://www.ccme.ca/files/Resources/water/groundwater/gw_phase1_smry_ en_1.1.pdf.

Carpenter, A.B., 1978, Origin and chemical evolution of brines in sedimentary basins , in Johnson, K.A., and Russell, J.A., eds., Thirteenth annual forum on the geology of industrial minerals: Oklahoma Geological Survey, Circular 79, p. $60-77$.

Carter, T.R., 1991, Dolomitization patterns in the Salina A-1 and A-2 Carbonate units, Sombra Township, Ontario: Ontario Petroleum Institute, $30^{\text {th }}$ Annual Conference, London, Ontario, v. 30, Technical Paper 4, 35 p.

Carter, T.R., 2012, Regional groundwater systems in southern Ontario: Ontario Petroleum Institute, Ontario Oil and Gas 2012, p. 44-48.

Carter, T.R., and Clark, J., 2018, Base of fresh water, inferred bedrock karst, and the contact aquifer in southern Ontario, as interpreted from water well records: Oil, Gas and Salt Resources Library, Open File Data Release 2018-1, 16 p.

Carter, T.R., and Fortner, L., 2012, Regional bedrock aquifers and a geological groundwater model for southern Ontario (Abstract): International Association of Hydrogeologists, $39^{\text {th }}$ International Congress Niagara Falls, Session TH1-G, Abstract 369, p. 238.

Carter, T.R., and Sutherland L., 2020, Interface mapping of hydrochemical groundwater regimes in the Paleozoic bedrock of southwestern Ontario, in Russell, H.A.J., and Kjarsgaard, B.A., eds., Summary of Southern Ontario groundwater project 2014-2019: Geological Survey of Canada, Open File 8536, p. 37-48, https://doi.org/10.4095/321083.

Carter, T.R., Trevail, R.A., and Smith, L., 1994, Core workshop: Niagaran reef and 
inter-reef relationships in the subsurface of southwestern Ontario: Geological Association of Canada-Mineralogical Association of Canada, Annual Meeting, Waterloo 1994, Field Trip A5 Guidebook, 38 p.

Carter, T.R., Trevail, R.A., and Smith, L., 1996, Geology of a natural gas storage pool: Silurian pinnacle reefs in southern Ontario: CSPG Core Conference, Pools '96, AEUB Core Research Centre, p. 3-1 to 3-10.

Carter, T.R., Wang, D., Castillo, A.C., and Fortner, L., 2015a, Water type maps of deep groundwater from petroleum well records, southern Ontario: Ontario Oil, Gas and Salt Resources Library, Open File Data Release 2015-1, 10 p. 89 maps.

Carter, T.R., Wang, D., Castillo, A.C., and Fortner, L., 2015b, Static level maps of deep groundwater from petroleum well records, southern Ontario: Ontario Oil, Gas and Salt Resources Library, Open File Data Release 2015-2, 11 p. 17 maps.

Carter, T.R., Hamilton, D., Phillips, A., Dorland, M., Colquhoun, I., Fortner, L., and Clark, J., 2016, Ontario oil and gas 3. Silurian and Devonian conventional plays: Canadian Society of Petroleum Geologists, Reservoir, v. 43, p. 18-26.

Carter, T.R., Brunton, F.R., Clark, J., Fortner, L., Freckelton, C.N., Logan, C.E., Russell, H.A.J., Somers, M., Sutherland L., and Yeung, K.H., 2017, Status report on three-dimensional geological and hydrogeological modelling of the Paleozoic bedrock of southern Ontario: Ontario Geological Survey, Summary of Field Work and Other Activities, 2017: Open File Report 6333, p. 28-1 to 28-15.

Carter, T.R., Brunton, F.R., Clark, J.K., Fortner, L., Freckelton, C., Logan, C.E., Russell, H.A.J., Somers, M., Sutherland, L., and Yeung, K.H., 2019, A three-dimensional geological model of the Paleozoic bedrock of southern Ontario: Geological Survey of Canada, Open File 8618, 45 p., https://doi.org/10.4095/315045.

Charbonneau, S.L., 1990a, Subaerial exposure and meteoric diagenesis in Guelph Formation (Niagaran) pinnacle reef bioherms of the Michigan Basin, south western Ontario: Unpublished MSc thesis, Queen's University, ON, 215 p.

Charbonneau, S.L., 1990b, Subaerial exposure of Middle Silurian Guelph Formation pinnacle reefs of the Michigan Basin, southwestern Ontario: Ontario Petroleum Institute, Technical Volume 29, Paper 17, $22 \mathrm{p}$

Chebotarev, I.I., 1955, Metamorphism of natural waters in the crust of weathering-1: Geochimica et Cosmochimica Acta, v. 8, p. 22-32, IN1-IN2, 33-48, https://doi.org/10.1016/0016-7037(55)90015-6.

Clark, I.D., Al, T., Jensen, M., Kennell, L., Mazurek, M., Mohapatra, R., and Raven, K.G., 2013, Paleozoic-aged brine and authigenic helium preserved in an Ordovician shale aquiclude: Geology, v. 41, p. 951-954, https://doi.org/10.1130/G34372.1.

Cole, J., Coniglio, M., and Gautrey, S., 2009, The role of buried bedrock valleys on the development of karstic aquifers in flat-lying carbonate bedrock: insights from Guelph, Ontario, Canada: Hydrogeology Journal, v. 17, p. 1411-1425, https://doi.org/10.1007/s10040-009-0441-3.

Coniglio, M., Sherlock, R., Williams-Jones, A.E., Middleton, K., and Frape, S.K., 1994, Burial and hydrothermal diagenesis of Ordovician carbonates from the Michigan Basin, Ontario, Canada, in Purser, B., Tucker, M., and Zenger, D., eds. Dolomites: A Volume in Honour of Dolomieu: International Association of Sedimentologists, Special Publications, v. 21, p. 231-254 https://doi.org/10.1002/9781444304077.ch14.

Coniglio, M., Zheng, Q., and Carter, T.R., 2003, Dolomitization and recrystallization of middle Silurian reefs and platformal carbonates of the Guelph Formation, Michigan Basin, southwestern Ontario: Bulletin of Canadian Petroleum Geology, v. 51, p. 177-199, https://doi.org/10.2113/51.2.177.

Cowell, D.W., 1976. Karst geomorphology of the Bruce Peninsula, Ontario: Unpublished MSc thesis, McMaster University, ON, 230 p.

Cowell, D.W., and Ford, D.C., 1983, Karst hydrology of the Bruce Peninsula, Ontario, Canada: Journal of Hydrology, v. 61, p. 163-168, https://doi.org/10.1016/0022-1694(83)90242-1

Craig, F.F., 1993, The reservoir engineering aspects of waterflooding: Society of Petroleum Engineers, 134 p.

Craig, H., 1961, Isotopic variations in meteoric waters: Science, v. 133, p. 1702-1703, https://doi.org/10.1126/science.133.3465.1702.

Davies, G.R., and Smith Jr., L.B., 2006, Structurally controlled hydrothermal dolomite reservoir facies: An overview: American Association of Petroleum Geologists Bulletin, v. 90, p. 1641-1690, https://doi.org/10.1306/05220605164.

Desaulniers, D.E., Cherry, J.A., and Fritz, P., 1981, Origin, age and movement of pore water in argillaceous Quaternary deposits at four sites in southwestern Ontario: Journal of Hydrology, v. 50, p. 231-257, https://doi.org/10.1016/0022-1694(81)90072-X.

Dieter, C.A., Maupin, M.A., Caldwell, R.R., Harris, M.A., Ivahnenko, T.I., Lovelace, J.K., Barber, N.L., and Linsey, K.S., 2018, Estimated use of water in the United States in 2015: U.S. Geological Survey, Circular 1441, 65 p., https://doi.org/10.3133/cir1441.

Dillon Consulting Ltd., and Golder Associates Ltd., 2004, Essex Region/Chatham-
Kent Region groundwater study volume 1: geology/hydrogeology evaluation: Essex Region Conservation Authority, $72 \mathrm{p}$

Dollar, P.S., 1988, Geochemistry of formation waters, southwestern Ontario, Canada and southern Michigan, USA: Implications for origin and evolution: Unpublished MSc thesis, University of Waterloo, ON, $129 \mathrm{p}$

Dollar, P.S., Frape, S.K., and McNutt, R.H., 1991, Geochemistry of formation waters, southwestern Ontario, Canada and southern Michigan, U.S.A.: Implications for origin and evolution: Ontario Geological Survey, Open File Report $5743,72 \mathrm{p}$.

Dorland, M., Colquhoun, I., Carter, T.R., Phillips, A., Fortner, L., Clark, J., and Hamilton, D., 2016, Ontario Oil and Gas. Cambrian and Ordovician conventional plays: Canadian Society of Petroleum Geologists, Reservoir, v. 43, p. $18-25$.

Dyer, B.D., 2003, A field guide to bacteria: Cornell University Press, Ithaca, NY, 355

Easton, R.M., 1992, The Grenville Province and the Proterozoic history of central and southern Ontario, in Thurston, P.C., Williams, H.R., Sutcliffe, R.H., and Stott, G.M., eds., Geology of Ontario: Ontario Geological Survey, Special Volume 4, Part 2, p. 714-904

Eberts, S.M., and George, L.L., 2000, Regional ground-water flow and geochemistry in the Midwest Basins and Arches aquifer system in parts of Indiana, Ohio, Michigan, and Illinois: United States Geological Survey, Professional Paper 1423-C, 103 p., https://doi.org/10.3133/pp1423C.

Ettensohn, F.R., 2008, Chapter 4 The Appalachian foreland basin in eastern United States, in Miall, A.D., ed., The Sedimentary Basins of the United States and Canada: Sedimentary Basins of the World, v. 5, p. 105-179, https://doi.org/10.1016/S1874-5997(08)00004-X.

Eyles, N., and Scheidegger, A.E., 1995, Environmental significance of bedrock jointing in southern Ontario, Canada: Environmental Geology, v. 26, p. 269-277, https://doi.org/10.1007/BF00770478.

Ferguson, G., and Jasechko, S., 2015, The isotopic composition of the Laurentide Ice Sheet and fossil groundwater: Geophysical Research Letters, v. 42, p. 4856-4861, https://doi.org/10.1002/2015GL064106.

Freckelton, C.N., 2012, A physical and geochemical characterization of southwestern Ontario's breathing well region: Unpublished MSc thesis, University of Western Ontario, ON, 242 p. Electronic thesis and dissertation repository, 1105 https://ir.lib.uwo.ca/etd/1105.

Freeze, R.A., and Cherry, J.A., 1979, Groundwater: Prentice-Hall Inc., Englewood Cliffs, New Jersey, USA, 603 p.

Frey, S.K., Khader, O., Taylor, A., Erler, A.R., Lapen, D.R., Sudicky, E.A., Berg, S.J., and Russell, H.A.J., 2020, A fully integrated groundwater-surface-water model for southern Ontario, in Russell, H.A.J., and Kjarsgaard, B.A., eds., Southern Ontario groundwater project 2014-2019: summary report: Geological Survey of Canada, Open File 8536, p. 231-245, https://doi.org/10.4095/321108.

Gao, C., 2011, Buried bedrock valleys and glacial and subglacial meltwater erosion in southern Ontario, Canada: Canadian Journal of Earth Sciences, v. 48, p. 801-818, https://doi.org/10.1139/e10-104.

Gao, C., Shirota, J., Kelly, R.I., Brunton, F.R., and Van Haaften, S., 2006, Bedrock topography and overburden thickness mapping, southern Ontario: Ontario Geological Survey, Miscellaneous Release-Data 207, 43 p.

Gill, D., 1977, Salina A-I sabkha cycles and the Late Silurian paleogeography of the Michigan Basin: Journal of Sedimentary Geology, v. A7, p. 979-1017.

Golder Associates Ltd., 2003, LLW geotechnical feasibility study, Western Waste Management Facility, Bruce site, Tiverton, Ontario: Golder Associates, Report to Municipality of Kincardine and Ontario Power Generation, Technical Report 021-1570, $129 \mathrm{p}$

Golder Associates Ltd., and Ontario Geological Survey, 2008, 3-D field investigation of Paleozoic bedrock and boreholes in thin-drift limestone-dolostone plains of southern Ontario: Ontario Geological Survey, Supplemental Report to Groundwater Resources Study 5, 53 p.

Grimes, D.J., 1987, Depositional models, subaerial facies, and diagenetic histories of the Rosedale and Fletcher reefs, southwestern Ontario: Unpublished MSc thesis, Queen's University, ON, $120 \mathrm{p}$

Haeri-Ardakani, O., Al-Aasm, I., and Coniglio, M., 2013, Petrologic and geochemical attributes of fracture-related dolomitization in Ordovician carbonates and their spatial distribution in southwestern Ontario, Canada: Marine and Petroleum Geology, v. 43, p. 409-422, https://doi.org/10.1016/j.marpetgeo.2012.12.006.

Hallet, B., 2011, Glacial erosion assessment: Nuclear Waste Management Organization, Report NWMO DGR-TR-2011-18, Toronto, Canada, 55 p.

Hamilton, G.D., 1991, Styles of reservoir development in Middle Devonian carbonates of southwestern Ontario: Unpublished MSc thesis, University of Waterloo, ON, $191 \mathrm{p}$.

Hamilton, S.M., 2015, Ambient groundwater geochemistry data for southern 
Ontario 2007-2014: Ontario Geological Survey, Miscellaneous Release Data 283 - Revised. Accessible at: http://www.geologyontario.mndm.gov.on.ca/mndmaccess/mndm_dir.asp?typ $\mathrm{e}=$ pub\&id=MRD283-REV.

Hamilton, S.M., Grasby, S.E., McIntosh, J.C., and Osborn, S.G., 2015, The effect of long-term regional pumping on hydrochemistry and dissolved gas content in an undeveloped shale-gas-bearing aquifer in southwestern Ontario, Canada: Hydrogeology Journal, v. 23, p. 719-739, https://doi.org/10.1007/s10040-0141229-7.

Hamilton, S.M., Brunton, F.R., and Priebe, E.H., 2017, Regional-scale mapping of buried, surface-connected, karstic groundwater systems using dissolved $\mathrm{CO}_{2-}$ $\mathrm{O}_{2}$ in groundwater (Abstract): IAH-CNC 70 ${ }^{\text {th }}$ Canadian Geotechnical Conference and $12^{\text {th }}$ Joint CGS/IAH-CNC Groundwater Conference, GeoOttawa 2017.

Hancock, P.L., and Engelder, T., 1989, Neotectonic joints: Geological Society of America Bulletin, v. 101, p. 1197-1208, https://doi.org/10.1130/00167606(1989) $101<1197: \mathrm{NJ}>2.3 . \mathrm{CO} ; 2$.

Harper, D.A., Longstaffe, F.J., Wadleigh, M.A., and McNutt, R.H., 1995, Secondary K-feldspar at the Precambrian-Paleozoic unconformity, southwestern Ontario: Canadian Journal of Earth Sciences, v. 32, p. 1432-1450, https://doi.org/10.1139/e95-116.

Hobbs, M.Y., Frape, S.K., Shouakar-Stash, O., and Kennell, L.R., 2011, Regional hydrogeochemistry - southern Ontario: Nuclear Waste Management Organization, Report NWMO DGR-TR-2011-12, Toronto, ON. Accessed June 11, 2013 at: https://archive.opg.com/pdf_archive/Deep\%20Geologic\%20Repository\%20Documents/Geoscience\%20Reports/D002_4.1.2_Regional-Hydrogeochemistry-Southern-Ontario.pdf .

Holser, W., 1979, Trace elements and isotopes in evaporites, in Burns, R.G., ed., Marine Minerals: Reviews in Mineralogy, v. 6, p. 295-346, https://doi.org/10.1515/9781501508646-013.

Howell, P.D., and van der Pluijm, B.A., 1990, Early history of the Michigan basin: Subsidence and Appalachian tectonics: Geology, v. 18, p. 1195-1198, https://doi.org/10.1130/0091-7613(1990)018<1195:EHOTMB > 2.3.CO;2.

Hurley, J., Merry, A.G., Wadley, S., Abbey, D., and Luinstra, B., 2008, Karst delineation and sinkhole investigation in the Ausable Bayfield Conservation Authority watershed and surrounding area: Ontario Geological Survey, Groundwater Resources Study 7, 49 p.

Husain, M.M., Cherry, J.A., Fidler, S., and Frape, S.K., 1998, On the long-term hydraulic gradient in the thick clayey aquitard in the Sarnia region, Ontario: Canadian Geotechnical Journal, v. 35, p. 986-1003, https://doi.org/10.1139/t98-057.

Husain, M.M., Cherry, J.A., and Frape, S.K. 2004, The persistence of a large stagnation zone in a developed regional aquifer, southwestern Ontario: Canadian Geotechnical Journal, v. 41, p. 943-958, https://doi.org/10.1139/t04-040.

Intera Technologies Ltd., 1988, Inventory and assessment of hydrogeological condition of underground openings in sedimentary rocks: Unpublished report to Ontario Hydro, H87-040.

Intera Engineering Ltd., 2011, Descriptive geosphere site model: Nuclear Waste Management Organization, Report NWMO DGR-TR-2011-24, 425 p. Accessed June 11, 2013 at: https://www.ceaa-acee.gc.ca/050/documents_staticpost $/ 17520 / 49820 /$ site_model.pdf.

Johnson, M.D., Armstrong, D.K., Sanford, B.V., Telford, P.G., and Rutka, M.A., 1992, Paleozoic and Mesozoic geology of Ontario, in Thurston, P.C., Williams, H.R., Sutcliffe, R.H., and Stott, G.M., eds, Geology of Ontario: Ontario Geological Survey, Special Volume 4, Part 2, p. 907-1010

Kaufmann, R.S., Frape, S.K., McNutt, R., and Eastoe, C., 1993, Chlorine stable isotope distribution of Michigan Basin formation waters: Applied Geochemistry, v. 8, p. 403-407, https://doi.org/10.1016/0883-2927(93)90008-5.

Knauth, L.P., and Beeunas, M.A., 1986, Isotope geochemistry of fluid inclusions in Permian halite with implications for the isotopic history of ocean water and the origin of saline formations waters: Geochimica et Cosmochimica Acta, v. 50, p. 419-433, https://doi.org/10.1016/0016-7037(86)90195-X.

Lidiak, E.G., and Ceci, V.M., 1991, Authigenic K-feldspar in the Precambrian basement of Ohio and its effect on tectonic discrimination of the granitic rocks: Canadian Journal of Earth Sciences, v. 28, p. 1624-1634, https://doi.org/10.1139/e91-145.

Logan, C.E., Russell, H.A.J., Bajc, A.F., Burt, A., Mulligan, R.P.M., and Sharpe, D.R., 2020, A three-dimensional surficial geological model of southern Ontario, in Russell, H.A.J., and Kjarsgaard, B.A., eds., Southern Ontario groundwater project 2014-2019: Summary report: Geological Survey of Canada, Open File 8536, p. 49-64.

Maxey, G.B., 1964, Hydrostratigraphic units: Journal of Hydrology, v. 2, p. 124-129, https://doi.org/10.1016/0022-1694(64)90023-X.
McIntosh, J.C., and Walter, L.M., 2006, Paleowaters in Silurian-Devonian carbonate aquifers: Geochemical evolution of groundwater in the Great Lakes region since the Late Pleistocene: Geochimica et Cosmochimica Acta, v. 70, p. 2454-2479, https://doi.org/10.1016/i.gca.2006.02.002.

McIntosh, J.C., Garven, G., and Hanor, J.S., 2011, Impacts of Pleistocene glaciation on large-scale groundwater flow and salinity in the Michigan Basin: Geofluids, v. 11, p. 18-33, https://doi.org/10.1111/j.1468-8123.2010.00303.x.

McIntosh, J.C., Schlegel, M.E., and Person, M., 2012, Glacial impacts on hydrologic processes in sedimentary basins: evidence from natural tracer studies: Geofluids, v. 12, p. 7-21, https://doi.org/10.1111/j.1468-8123.2011.00344.x.

McIntosh, J.C., Grasby, S.E., Hamilton, S.M., and Osborn, S.G., 2014, Origin, distribution and hydrogeochemical controls on methane occurrences in shallow aquifers, southwestern Ontario, Canada: Applied Geochemistry, v. 50, p. 37-52, https://doi.org/10.1016/j.apgeochem.2014.08.001.

McNutt, R.H., Frape, S.K., and Dollar, P., 1987, A strontium, oxygen and hydrogen isotopic composition of brines, Michigan and Appalachian Basins, Ontario and Michigan: Applied Geochemistry, v. 2, p. 495-505, https://doi.org/10.1016/0883-2927(87)90004-7.

Middleton, K., Coniglio, M., Sherlock, R., and Frape, S.K., 1993, Dolomitization of Middle Ordovician carbonate reservoirs, southwestern Ontario: Bulletin of Canadian Petroleum Geology, v. 41, p. 150-163.

Mussman, W.J., and Read, J.F., 1986, Sedimentology and development of a passiveto convergent-margin unconformity: Middle Ordovician Knox unconformity, Virginia Appalachians: Geological Society of America Bulletin, v. 97, p. 282-295, https://doi.org/10.1130/0016-7606(1986)97<282:SADOAP> 2.0.CO;2.

Novakowski, K.S., and Lapcevic, P.A., 1988, Regional hydrogeology of the Silurian and Ordovician sedimentary rock underlying Niagara Falls, Ontario Canada: Journal of Hydrology, v. 104, p. 211-236, https://doi.org/10.1016/00221694(88)90166-7.

NWMO. Nuclear Waste Management Organization, 2011, Geosynthesis: Nuclear Waste Management Organization, Report NWMO DGR-TR-2011-11, Toronto, Canada. Accessed June 11, 2013 at: https://www.acee-ceaa.gc.ca/050/documents_staticpost/17520/49820/geosynthesis.pdf.

NWMO. Nuclear Waste Management Organization, and AECOM Canada Ltd., 2011, Regional geomechanics - southern Ontario: Nuclear Waste Management Organization, Report DGR-TR-2011-13, 88 p. Accessed June 11, 2013 at: http://www.nwmo.ca/uploads/DGR\%20PDF/Geo/Regional-Geomechanics-Southern-Ontario.pdf.

Priebe, E.H., and Brunton, F.R., 2016, Regional-scale groundwater mapping in the Early Silurian carbonates of the Niagara Escarpment: Final Update; in Summary of Field Work and Other Activities, 2016: Ontario Geological Survey, Open File Report 6323, p. 29-1 to 29-10.

Priebe, E.H., Brunton, F.R., and Lee, V.L., 2012, Regional-scale groundwater mapping in Early Silurian carbonate rocks of the Niagara Escarpment cuesta: multilevel monitoring well sampling: Ontario Geological Survey, Summary of Field Work 2012, Open File Report 6280, p. 35-1 to 35-11.

Priebe, E.H., Neville, C.J., and Brunton, F.R., 2017, Discrete, high-quality hydraulic conductivity estimates for the Early Silurian carbonates of the Guelph Region: Ontario Geological Survey, Groundwater Resources Study 16, 45 p., plus digital hydraulic test analyses.

Priebe, E.H., Brunton, F.R., Rudolph, D.L., and Neville, C.J., 2019, Geologic controls on hydraulic conductivity in a karst-influenced carbonate bedrock groundwater system in southern Ontario, Canada: Hydrogeology Journal, v. 27, p. 1291-1308, https://doi.org/10.1007/s10040-018-1911-2.

Priebe, E.H., Frape, S.K., Jackson, R.E., Rudolph, D.L., and Brunton, F.R., 2021, Tracing recharge and groundwater evolution in a glaciated, regional-scale carbonate bedrock aquifer system, southern Ontario, Canada: Applied Geochemistry, v. 124, 104794, https://doi.org/10.1016/j.apgeochem.2020.104794.

Raven, K.G., Lafleur, D.W., and Sweezey, R.A., 1990, Monitoring well into abandoned deep-well disposal formations at Sarnia, Ontario: Canadian Geotechnical Journal, v. 27, p. 105-118, https://doi.org/10.1139/t90-010.

Raven, K., Novakowski, K., Yager, R., and Heystee, R., 1992, Supernormal fluid pressures in sedimentary rocks of southern Ontario - western New York state: Canadian Geotechnical Journal, v. 29, p. 80-93, https://doi.org/10.1139/t92009 .

Ruberg, S.A., Kendall, S.T., Biddanda, B.A., Black, T., Nold, S.C., Lusardi, W.R., Green, R., Casserley, T., Smith, E., Sanders, T.G., Lang, G.A., and Constant, S.A., 2008, Observations of the Middle Island sinkhole in Lake Huron - A unique hydrogeologic and glacial creation of 400 million years: Marine Technology Society Journal, v. 42, p. 12-21, https://doi.org/10.4031/002533208787157633.

Russell, H.A.J., Arnaud, E., Bajc, A.F., and Sharpe, D.R., editors, 2018, Quaternary 
geology of southern Ontario and applications to hydrogeology: Introduction: Canadian Journal of Earth Sciences, v. 55, p. v-viii, https://doi.org/10.1139/cjes-2018-0119.

Sanford, B.V., 1969, Silurian of southwestern Ontario: Ontario Petroleum Institute, $8^{\text {th }}$ Annual Conference, Toronto, Ontario, v. 8, Technical Paper 5, 44 p.

Sanford, B.V., 1977, Distribution, thickness and three-dimensional geometry of salt deposits in southwestern Ontario: Geological Survey of Canada, Open File 401, 11 sheets, https://doi.org/10.4095/129206.

Sanford, B.V., and Quillian, R.G., 1959, Subsurface stratigraphy of Upper Cambrian rocks in southwestern Ontario: Geological Survey of Canada, Paper 58-12, 17 p.

Sanford, B.V., Thompson, F.J., and McFall, G.H., 1985, Plate tectonics-A possible controlling mechanism in the development of hydrocarbon traps in southwestern Ontario: Bulletin of Canadian Petroleum Geology, v. 33, p. 52-71.

Seaber, P.R., 1988, Hydrostratigraphic units, in Back, W., Rosenshein, J.R., and Seaber, P.R., eds., Hydrogeology: Geological Society of America, v. O-2, p. 9-14, https://doi.org/10.1130/DNAG-GNA-O2.9.

Sears, S.O., and Lucia, F.J, 1979, Reef growth model for Silurian pinnacle reefs, northern Michigan reef trend: Geology, v. 7, p. 299-302, https://doi.org/10.1130/0091-7613(1979)7<299:RMFSPR>2.0.CO;2.

Shafeen, A., and Carter, T.R., 2009, Geological sequestration of greenhouse gases, in Kutz, M., and Elkamel, A., eds., Environmentally Conscious Fossil Energy Production: John Wiley \& Sons Inc., p. 207-241, https://doi.org/10.1002/9780470432747.ch6.

Shafeen, A., Croiset, E., Douglas, P.L., and Chatzis, I., 2004, $\mathrm{CO}_{2}$ sequestration in Ontario, Canada. Part I: Storage evaluation of potential reservoirs: Energy Conversion and Management, v. 45, p. 2645-2659, https://doi.org/10.1016/j.enconman.2003.12.003.

Sharpe, D.R., Piggott, A., Carter, T.R., Gerber, R.E., MacRitchie, S.M., de Loë, R.C., Strynatka, S., and Zwiers, G., 2014, Southern Ontario hydrogeological region, in Rivera, A., ed., Canada's Groundwater Resources: Fitzhenry and Whiteside, Canada, p. 443-499, https://doi.org/10.4095/296947.

Shouakar-Stash, O., 2008, Evaluation of stable chlorine and bromine isotopes in sedimentary formation fluids: Unpublished $\mathrm{PhD}$ thesis, University of Waterloo, ON, $355 \mathrm{p}$.

Singer, S.N., Cheng, C., and Scafe, M.G., 2003, The hydrogeology of southern Ontario ( $2^{\text {nd }}$ edition): Ministry of the Environment, Hydrogeology of Ontario Series Report 1, $402 \mathrm{p}$

Skuce, M.E., 2014, Isotopic fingerprinting of shallow and deep groundwaters in southwestern Ontario and its applications to abandoned well remediation: Unpublished MSc thesis, University of Western Ontario, ON, 267 p., Electronic thesis and dissertation repository, 1926, https://ir.lib.uwo.ca/etd/1926.

Skuce, M., Longstaffe, F.J., Carter, T.R., and Potter, J., 2015a, Isotopic fingerprinting of groundwaters in southwestern Ontario: Applications to abandoned well remediation: Applied Geochemistry, 58, p. 1-13, https://doi.org/10.1016/j.apgeochem.2015.02.016.

Skuce, M., Potter, J., and Longstaffe, F., 2015b, The isotopic characterization of natural gas and water in Paleozoic bedrock formations in southwestern Ontario, Volume I: Water geochemistry - Abandoned Works Program: Ontario: Oil, Gas and Salt Resources Library, Open File Data Release 2015-3, 51 p.

Sloss, L.L., 1988, Tectonic evolution of the craton in Phanerozoic time; in Sloss, L.L., ed., Sedimentary Cover-North American Craton: Geological Society of America, v. D-2, p. 25-51, https://doi.org/10.1130/DNAG-GNA-D2.25.

Smith, L., 1990, Karst episodes during cyclic development of Silurian reef reservoirs, southwestern Ontario, in Carter, T.R., ed., Subsurface geology of southwestern Ontario - a core workshop: Ontario Petroleum Institute, 555 Southdale Road E, London, ON, p. 69-88.

Smith, L., Grimes, D.J., and Charbonneau, S.L., 1988, Karst episodes and permeability development, Silurian reef reservoirs, Ontario, in Milne, V.G., ed., Geoscience Research Grant Program Summary of Research 1987-1988: Ontario Geological Survey, Miscellaneous Paper 140, p. 124-132.

Stanton, J.S., Anning, D.W., Brown, C.J., Moore, R.B., McGuire, V.L., Qi, S.L., Harris, A.C., Dennehy, K.F., McMahon, P.B., Degnan, J.R., and Böhlke, J.K., 2017, Brackish groundwater in the United States: United States Geological Survey, Professional Paper 1833, 185 p., https://doi.org/10.3133/pp1833.

Strynatka, S., Balakrishna, T., Harvey, G., and Sarvas, P., 2007, Essex region groundwater resources study: Ontario Geological Survey, Groundwater Resources Study 2, $40 \mathrm{p}$.

Sun, S., 2018, Stratigraphy of the Upper Silurian to Middle Devonian, southwestern Ontario: Unpublished $\mathrm{PhD}$ thesis, University of Western Ontario, ON, 281 p. Electronic thesis and dissertation repository, 5230, https://ir.lib.uwo.ca/etd/5230.

Sun, S., Brunton, F.R., Carter, T.R., Jin, J., Irwin, C., Clark, J., and Yeung, K., 2020,
GIS analysis of porosity and permeability variations in the Silurian Lockport Group, southwestern Ontario (Abstract): Canadian Society of Petroleum Geologists, Geoconvention 2020.

Sykes, J.F., Normani, S.D., and Yin, Y., 2011, Hydrogeologic modelling: Nuclear Waste Management Organization, Report NWMO DGR-TR-2011-16, Toronto, ON, 428 p. Accessed June 11, 2013 at: http://www.ceaaacee.gc.ca/050/documents/56540/56540E.pdf.

Trevail, R.A., 1990, Cambro-Ordovician shallow water sediments, London area, southwestern Ontario, in Carter, T.R., ed., Subsurface Geology of Southwestern Ontario: A Core Workshop: Ontario Petroleum Institute, London, Ontario, p. $29-50$.

Weaver, T.R., 1994, Groundwater flow and solute transport in shallow Devonian bedrock formations and overlying Pleistocene units, Lambton County, southwestern Ontario: Unpublished PhD thesis, University of Waterloo, ON, $401 \mathrm{p}$.

Weaver, T.R., Frape, S.K., and Cherry, J.A., 1995, Recent cross-formational fluid flow and mixing in the shallow Michigan Basin: Geological Society of America Bulletin, v. 107, p. 697-707, https://doi.org/10.1130/0016-7606(1995)107 $<0697$ :RCFFFA $>2.3$.CO;2.

Wilson, T.P., and Long, D.T., 1993, Geochemistry and isotope chemistry of $\mathrm{Ca}-\mathrm{Na}-\mathrm{Cl}$ brines in Silurian strata, Michigan Basin, U.S.A.: Applied Geochemistry, v. 8, p. 507-524, https://doi.org/10.1016/0883-2927(93)90079-V.

Ziegler, K., and Longstaffe, F.J., 2000a, Clay mineral authigenesis along a mid-continental scale fluid conduit in Palaeozoic sedimentary rocks from southern Ontario, Canada: Clay Minerals, v. 35, p. 239-260, https://doi.org/10.1180/000985500546620.

Ziegler, K., and Longstaffe, F.J., 2000b, Multiple episodes of clay alteration at the Precambrian/Paleozoic unconformity, Appalachian Basin: Isotopic evidence for long-distance and local fluid migrations: Clays and Clay Minerals, v. 48, p. 474-493, https://doi.org/10.1346/CCMN.2000.0480407.

\section{Received December 2020}

Accepted as revised February 2021 